\title{
ESEQUIEL LIUSON
}

Pesquisa de coliformes totais, fecais e Salmonella spp em tilápias de pesqueiros da região metropolitana de São Paulo

São Paulo

2003 
ESEQUIEL LIUSON

Pesquisa de coliformes totais, fecais e Salmonella spp em tilápias de pesqueiros da região metropolitana de São Paulo

Dissertação apresentada ao Programa de Pós-graduação em Epidemiologia Experimental e Aplicada às Zoonoses da Faculdade de Medicina Veterinária e Zootecnia da Universidade de São Paulo para a obtenção do título de Mestre em Medicina Veterinária

\section{Departamento:}

Medicina Veterinária Preventiva e Saúde Animal

\section{Área de Concentração:}

Epidemiologia Experimental e Aplicada às Zoonoses

\section{Orientadora:}

Prof $^{\mathrm{a}}$. Dr ${ }^{\mathrm{a}}$. Simone de Carvalho Balian

São Paulo 
Autorizo a reprodução parcial ou total desta obra, para fins acadêmicos, desde que citada a fonte.

DADOS INTERNACIONAIS DE CATALOGAÇÃO-NA-PUBLICAÇÃO

(Biblioteca da Faculdade de Medicina Veterinária e Zootecnia da Universidade de São Paulo)

T.1304 Liuson, Esequiel

FMVZ Pesquisa de coliformes totais, fecais e Salmonella spp em tilápias de pesqueiros da região metropolitana de São Paulo / Esequiel Liuson -- São Paulo : E. Liuson, 2003.

93 f. : il.

Dissertação (mestrado) - Universidade de São Paulo. Faculdade de Medicina Veterinária e Zootecnia. Departamento de Medicina Veterinária Preventiva e Saúde Animal, 2003.

Programa de Pós-graduação: Epidemiologia Experimental e Aplicada às Zoonoses.

Área de concentração: Epidemiologia Experimental e Aplicada às Zoonoses.

Orientador: Profa. Dra. Simone de Carvalho Balian.

1. Coliformes. 2. Salmonella. 3. Piscicultura. 4. Pescado (microbiologia). 5. Tilápia. I. Título. 


\section{FOLHA DE AVALIAÇÃO}

Nome o autor: LIUSON, Esequiel

Título: Pesquisa de coliformes totais, fecais e Salmonella spp em tilápias de pesqueiros da região metropolitana de São Paulo.

Dissertação apresentada ao Programa de Pós-graduação em Epidemiologia Experimental e Aplicada às Zoonoses da Faculdade de Medicina Veterinária e Zootecnia da Universidade de São Paulo para a obtenção do título de Mestre em Medicina Veterinária

Data:

\section{Banca Examinadora}

Prof. Dr. Instituição:

Assinatura: Julgamento:

Prof. Dr. Instituição:

Assinatura: Julgamento:

Prof. Dr. Instituição:

Assinatura: Julgamento: 


\section{DEDICATÓRIA}

A meus pais por nunca medirem esforços para me proporcionar a melhor educação 


\section{AGRADECIMENTOS}

À minha orientadora Simone de Carvalho Balian, por toda dedicação, apoio, confiança e tantas oportunidades de crescimento pessoal e profissional a mim oferecidas

À Dra. Agar Costa Alexandrino de Pérez pela amizade e exemplo

Ao Prof. Dr. Silvio Arruda Vasconcelos pelo conhecimento adquirido

Ao Prof. Dr. José Cezar Panetta pelos ensinamentos

Ao Pesquisador Carlos Massatoshi Ishikawa pelo companheirismo e esforço conjunto

À Dra. Katharina Eichbaum Esteves pela oportunidade de participação e concretização do projeto

À Dra. Evelise O. T. R. e Silva pelas dicas e incentivos profissionais constantes

Ao Dr. Francisco Sergio Ferreira Jardim, Delegado Federal da Agricultura no Estado de São Paulo, pelas oportunidades proporcionadas

Ao Dr. Mário Roberto do Nascimento e Dr. Ari Crispim dos Anjos do Ministéro da Agricultura pela compreensão e incentivos

Ao Dr. Célio Faulhaber, Dr. Guilherme Antônio da Costa Junior, Dra. Luciana Andrade de Santana e Dr. Vital Vaz Neto do SEPES pela confiança, oportunidades e ensinamentos sobre a Inspeção de Pescado

Aos chefes e colegas Dr. Massafumi Shida, Dr. Sebastião Buff Blumer Bastos, Fábio e Marielen do SIPA/ DFA/ SP

Aos amigos e pesquisadores Agar, Ishikawa, Katharina, Neuza, Mazé, Thais, Beth, Maurício, Júlio, Estevar, Márcia Barbieri, Ocimar, Cláudia e Leonel do Instituto de Pesca - SP 
À Dra. Vera Regina pelas oportunidades acadêmicas, confiança depositada e amizade

Ao Bispo e Sandrinha que tanto me ensinaram no laboratório

À colega Flávia Bernardi Paes Leme pela ajuda e empenho na exaustiva realização das análises laboratoriais

A todos do VPS em especial a Tânia, Virgínia, Cristina, Danival e também à Sandra, Cláudia e Dayse, por tantas dúvidas esclarecidas

A todos da Biblioteca pela ajuda na compreensão das diretrizes para apresentação de dissertações e teses na FMVZ - USP

Aos colegas da pós-graduação principalmente aos dos alimentos, Paula(s), Neusa, Esther, Flávia e Juliana

A todos do laboratório de bioestatística em especial ao Prof. Dr. Marcos Amaku e Ricardo A. Dias pelo auxílio nas análises estatísticas

Aos proprietários de pesqueiros que permitiram a colheita de amostras em suas propriedades

À Cecília Tiemi Tanabe pela paciência, companheirismo e ajuda na finalização dos trabalhos

À FAPESP pelo auxílio à pesquisa, processo 01/04081 


\section{RESUMO}

LIUSON, E. Pesquisa de coliformes totais, fecais e Salmonella spp em tilápias de pesqueiros da região metropolitana de São Paulo. [Research of total, fecal coliforms and Salmonella spp in tilapia used in "pesqueiros" of the metropolitan area of São Paulo]. 2003. 93 f. Dissertação (Mestrado em Epidemiologia Experimental e Aplicada às Zoonoses) - Faculdade de Medicina Veterinária e Zootecnia, Universidade de São Paulo, São Paulo, 2003.

A principal fonte de escoamento da piscicultura no Brasil, são os pesqueiros comerciais (“pesque-pagues”), que recebem cerca de $90 \%$ da produção. A tilápia é um dos peixes mais utilizados nestas criações dado a sua rusticidade, fácil manejo, alto rendimento e grande aceitação. É inegável a contribuição que os pesqueiros trazem para a atividade, pois propiciam, além do lazer, uma divulgação do produto, aumento do consumo e até mudanças nos hábitos alimentares. Porém, com a internacionalização dos hábitos alimentares, pratos com peixes crus, típicos da culinária japonesa, tem sido servidos ao consumo nos pesqueiros sem qualquer controle sanitário ou inspeção veterinária. Estes peixes podem contrair uma variada gama de microrganismos em águas poluídas por contaminação fecal tornando o pescado um importante veiculador de agentes patogênicos responsáveis por diversas doenças no homem. O crescimento desordenado deste segmento, oferece portanto, produtos de qualidade duvidosa colocando em risco a saúde do consumidor, sendo indispensável desenvolver o setor buscando a qualidade e segurança do pescado produzido. O presente trabalho pesquisou coliformes totais, fecais e Salmonella spp em tilápias (Oreochromis spp) em 30 pesqueiros da região metropolitana de São Paulo. Foram analisados 180 peixes na época seca e fria, entre os meses de setembro e outubro de 2001; e 180 peixes na época chuvosa e quente, entre fevereiro e março de 2002. Os resultados revelaram que $70 \%$ dos pesqueiros estudados apresentaram coliformes fecais e/ou Salmonella spp em desacordo com a legislação, 
sendo que $63,3 \%$ dos pesqueiros apresentaram coliformes fecais, em níveis acima do permitido pela legislação e $20 \%$ a presença de Salmonella spp, independentemente do período do ano estudado. Conclui-se portanto que nos pesqueiros estudados foram encontrados peixes contaminados por coliformes fecais e Salmonella spp, com valores em desacordo com a legislação, estando impróprios para o consumo humano direto.

Palavras-chave: Coliformes. Salmonella. Piscicultura. Pescado (microbiologia). Tilápia. 


\begin{abstract}
LIUSON, E. Research of total, fecal coliforms and Salmonella spp in tilapia used in "pesqueiros" of the metropolitan area of São Paulo. [Pesquisa de coliformes totais, fecais e Salmonella spp em tilápias de pesqueiros da região metropolitana de São Paulo]. 2003. 93 f. Dissertação (Mestrado em Epidemiologia Experimental e Aplicada às Zoonoses) - Faculdade de Medicina Veterinária e Zootecnia, Universidade de São Paulo, São Paulo, 2003.
\end{abstract}

The main source of drainage of the fish farming in Brazil, are the "pesqueiros comerciais" (fish and pay), they receive about $90 \%$ of the production. The tilapia is one of the fish more used in these fish farming for their rusticity, easy handling, high income and great acceptance. It is undeniable the contribution that the "pesqueiros" bring for the activity, because they propitiate, besides the leisure, a popularization of the product, increase of the consumption and changes in the alimentary habits. However, with the internationalization of the alimentary habits, plates with raw fish, typical of the Japanese cookery, has been served to the consumption in the "pesqueiros" without any sanitary control or veterinary inspection. These fish can contract a varied range of microorganisms in waters polluted by fecal contamination turning the fish an important pathogenic agent disseminator responsible for several diseases in the man. The disordered growth of this segment, offers products of doubtful quality putting in risk the consumer's health, being indispensable to develop the section looking for the quality and safety of the produced fish. The present work researched total, fecal coliforms and Salmonella spp in tilapias (Oreochromis spp) in 30 "pesqueiros" of the metropolitan area of São Paulo. They were analyzed 180 fish at dries and cold time, between the months of September and October of 2001; and 180 fish at rainy and hot time, between February and March of 2002. The results revealed that 70\% of the "pesqueiros" studied presented fecal coliforms and/or Salmonella spp in disagreement with the legislation, 
and $63,3 \%$ of the "pesqueiros" presented fecal coliforms, in levels above allowed by the legislation and $20 \%$ the presence of Salmonella spp, independently of the period of the studied year. It was concluded that in the "pesqueiros" studied fish were found contaminated by fecal coliforms and Salmonella spp, in values in disagreement with the legislation, being inappropriate for the direct human consumption.

Key words: Coliforms. Salmonella. Fish farming. Fishery (microbiology). Tilapia. 


\section{LISTA DE TABELAS}

Tabela 1 - Número mais provável por grama de coliformes totais das amostras analisadas durante o período seco e frio (SE) em pesqueiros da região metropolitana de São Paulo - São Paulo - set 2001 - out 2001.

Tabela 2 - Número mais provável por grama de coliformes totais das amostras analisadas durante o período chuvoso e quente $(\mathrm{CH})$ em pesqueiros da região metropolitana de São Paulo - São Paulo - fev 2002 - mar 2002....44

Tabela 3 - Distribuição das amostras colhidas durante os períodos seco e frio (SE); chuvoso e quente $(\mathrm{CH})$ de acordo com a ocorrência de coliformes totais em $\mathrm{NMP} / \mathrm{g}$ apresentados em intervalos de um ciclo logarítmico, em pesqueiros da região metropolitana de São Paulo - São Paulo - set 2001 - out $2001 /$ fev 2002 - mar 2002 .

Tabela 4 - Distribuição dos pesqueiros nos períodos seco e frio (SE); chuvoso e quente $(\mathrm{CH})$ e em ambos ( $\mathrm{SE}$ e $\mathrm{CH})$ de acordo com os resultados de coliformes totais em NMP/g da amostra com mais alto valor, apresentados por intervalos de um ciclo logarítmico - São Paulo - set 2001 - out 2001/fev 2002 - mar 2002.

Tabela 5 - Número mais provável por grama de coliformes fecais das amostras analisadas durante o período seco e frio (SE) em pesqueiros da região metropolitana de São Paulo - São Paulo - set 2001 - out 2001.

Tabela 6 - Número mais provável por grama de coliformes fecais das amostras analisadas durante os períodos chuvoso e quente $(\mathrm{CH})$ em pesqueiros da região metropolitana de São Paulo - São Paulo - fev 2002 - mar 2002 ....50

Tabela 7 - Número de amostras classificadas como positivas para coliformes fecais nos períodos seco e frio (SE); chuvoso e quente $(\mathrm{CH})$ e em ambos, em pesqueiros da região metropolitana de São Paulo - São Paulo - set 2001 out $2001 /$ fev 2002 - mar 2002 .

Tabela 8 - Distribuição dos pesqueiros estudados, da região metropolitana de São Paulo, durante os períodos seco e frio $(\mathrm{SE})$; chuvoso e quente $(\mathrm{CH})$ e em ambos ( $\mathrm{SE}$ e $\mathrm{CH}$ ) de acordo com o número de amostras positivas para coliformes fecais - São Paulo - set 2001 - out 2001/fev 2002 - mar 2002

Tabela 9 - Distribuição dos pesqueiros estudados, da região metropolitana de São Paulo, durante os períodos seco e frio $(\mathrm{SE})$; chuvoso e quente $(\mathrm{CH})$ e em ambos (SE e $\mathrm{CH})$ de acordo com uma ocorrência crescente de amostras positivas para coliformes fecais - São Paulo - set 2001 - out 2001/fev 2002 - mar 2002. .55 
Tabela 10 - Pesquisa de Salmonella spp nas três amostras de peixe analisadas durante o período seco e frio (SE) em pesqueiros da região metropolitana de São Paulo - São Paulo - set 2001 - out 2001. 56

Tabela 11 - Pesquisa de Salmonella spp nas três amostras de peixe analisadas durante o período chuvoso e quente $(\mathrm{CH})$ em pesqueiros da região metropolitana de São Paulo - São Paulo - fev 2002 - mar 2002

Tabela 12 - Distribuição do número de amostras positivas para Salmonella spp, nos períodos seco e frio $(\mathrm{SE})$; chuvoso e quente $(\mathrm{CH})$ e em ambos $(\mathrm{SE}$ e $\mathrm{CH})$, em pesqueiros da região metropolitana de São Paulo-São Paulo - set 2001 - out $2001 /$ fev 2002 - mar 2002 . .58

Tabela 13 - Distribuição dos pesqueiros estudados, da região metropolitana de São Paulo durante os períodos seco e frio (SE); chuvoso e quente $(\mathrm{CH})$ e em ambos (SE e $\mathrm{CH}$ ), de acordo com o número de amostras positivas para Salmonella spp - São Paulo - set 2001 - out 2001/fev 2002 - mar 2002. .61

Tabela 14 - Distribuição dos pesqueiros estudados, da região metropolitana de São Paulo, durante os períodos seco e frio (SE); chuvoso e quente $(\mathrm{CH})$ e em ambos ( $\mathrm{SE}$ e $\mathrm{CH}$ ), de acordo com o número de amostras positivas para Salmonella spp - São Paulo - set 2001 - out 2001/fev 2002 - mar 2002

Tabela 15 - Presença de coliformes fecais ou Salmonella spp nas amostras colhidas durante os períodos seco e frio $(\mathrm{SE})$; chuvoso e quente $(\mathrm{CH})$, em relação a presença de pelo menos uma amostra positiva, nos pesqueiros da região metropolitana de São Paulo - São Paulo - fev 2002 - mar 2002

Tabela 16 - Distribuição durante os períodos seco e frio (SE); chuvoso e quente $(\mathrm{CH})$, de acordo com os resultados positivos encontrados de coliformes fecais ou Salmonella spp encontrados em pelo menos uma das amostras colhidas dos pesqueiros da região metropolitana de São Paulo - São Paulo - fev 2002 mar 2002 .

Tabela 17 - Distribuição durante os períodos seco e frio; chuvoso e quente, dos pesqueiros e amostras, de acordo com resultados positivos encontrados de coliformes fecais ou Salmonella spp encontrados nas amostras colhidas nos pesqueiros da região metropolitana de São Paulo - São Paulo - fev 2002 mar 2002 .

Tabela 18 - Comportamento dos pesqueiros estudados, da região metropolitana de São Paulo em relação à presença de coliformes fecais, Salmonella spp e coliformes fecais ou Salmonella spp que apresentaram pelo menos uma amostra positiva do período seco e frio para o chuvoso e quente - São Paulo - set 2001 - out 2001/fev 2002 - mar 2002.

Tabela 19 - Presença de coliformes fecais, Salmonella spp, animais na propriedade e agricultura nos 30 pesqueiros da região metropolitana de São Paulo, 
considerando positivos, os que apresentaram a presença destes fatores São Paulo - set 2001 - out 2001/fev 2002 - mar 2002

Tabela 20 - Valores obtidos do nível de significância, valor de p, obtidos na aplicação dos testes Qui Quadrado e Fischer, na verificação de associação entre período seco e frio; chuvoso e quente, presença ou ausência de outros animais na propriedade e agricultura e pesqueiros positivos para coliformes fecais, Salmonella spp, coliformes fecais e/ou Salmonella spp - São Paulo - set 2001 - out 2001/fev 2002 - mar 2002 


\section{LISTA DE FIGURAS}

Figura 1 - Localização dos 30 pesqueiros estudados na região metropolitana de São Paulo - São Paulo - set 2001 - out 2001/fev 2002 - mar 2002.

Figura 2 - Distribuição em porcentagem, das 180 amostras colhidas durante os períodos seco e frio (SE); chuvoso e quente $(\mathrm{CH})$ de acordo com a ocorrência de coliformes totais em NMP/g apresentados em intervalos de um ciclo logarítmico, em 30 pesqueiros da região metropolitana de São Paulo - São Paulo - set 2001 - out 2001/fev 2002 - mar 2002 .......................................46

Figura 3 - Distribuição em porcentagem, dos 30 pesqueiros nos períodos seco e frio (SE); chuvoso e quente $(\mathrm{CH})$ e em ambos (SE e $\mathrm{CH}$ ) de acordo com os resultados de maior valor para coliformes totais em NMP/g apresentados por intervalos de um ciclo logarítmico - São Paulo - set 2001 - out $2001 /$ fev 2002 - mar 2002

Figura 4 - Porcentagem de amostras positivas para coliformes fecais de um total de 180 amostras colhidas em 30 pesqueiros da região metropolitana de São Paulo, independentemente do período estudado - São Paulo - set 2001 - out 2001/fev 2002 - mar 2002. .53

Figura 5 - Porcentagem de amostras positivas para Salmonella spp de um total de 180 amostras colhidas em 30 pesqueiros da região metropolitana de São Paulo, independentemente do período estudado - São Paulo - set 2001 - out $2001 /$ fev 2002 - mar 2002

Figura 6 - Porcentagem de pesqueiros positivos para coliformes fecais, do total de 30 pesqueiros da região metropolitana de São Paulo estudados, independentemente do período analisado - São Paulo - set 2001 - out $2001 /$ fev 2002 - mar 2002 .64

Figura 7 - Porcentagem de pesqueiros positivos para Salmonella spp, do total de 30 pesqueiros da região metropolitana de São Paulo estudados, independentemente do período analisado - São Paulo - set 2001 - out $2001 /$ fev 2002 - mar 2002

Figura 8 - Porcentagem de pesqueiros positivos para coliformes fecais ou Salmonella spp, do total de 30 pesqueiros da região metropolitana de São Paulo estudados, independentemente do período analisado - São Paulo - set 2001 - out $2001 /$ fev 2002 - mar 2002 . .65 
LISTAS DE SÍMBOLOS

\begin{tabular}{ll}
$\%$ & porcentagem \\
$<$ & menor \\
$=$ & maior \\
+ & igual \\
${ }^{\circ} \mathrm{C}$ & mais \\
$\mathrm{g}$ & graus Celsius \\
$\mathrm{Kg}$ & grama \\
$\mathrm{ml}$ & quilograma \\
$\mathrm{L}$ & mililitro \\
$\mathrm{h}$ & litro \\
\hline
\end{tabular}




\section{SUMÁRIO}

1 INTRODUÇÃ

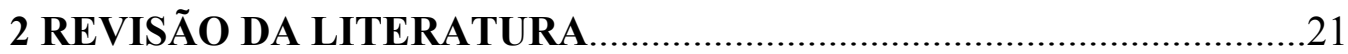

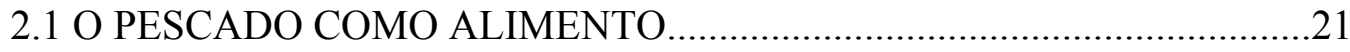

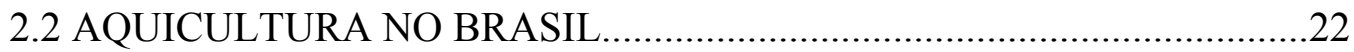

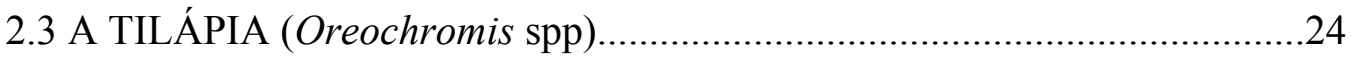

2.4 POLUIÇÃO DAS ÁGUAS E SUA INFLUÊNCIA NA QUALIDADE DO

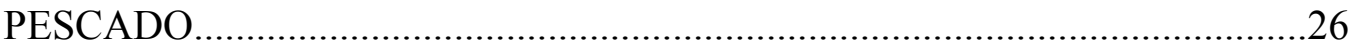

2.5 O PESCADO COMO VIA DE TRANSMISSÃO DE AGENTES

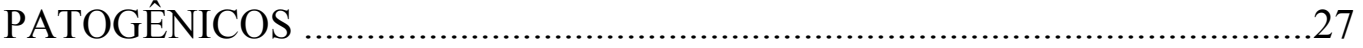

2.6 COLIFORMES TOTAIS, FECAIS E Salmonella spp...............................29

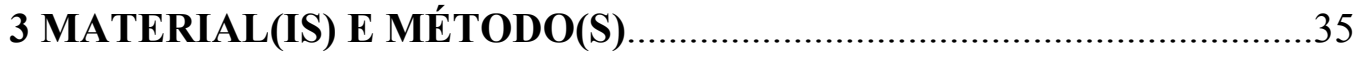

3.1 TÉCNICA DA LAVAGEM SUPERFICIAL ................................................

3.2 PRÉ-PREPARO DAS AMOSTRAS PARA ANÁLISE...............................38

3.3 ENUMERAÇÃO DE COLIFORMES TOTAIS E FECAIS EM NMP/g.....39

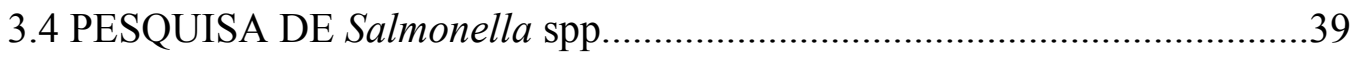

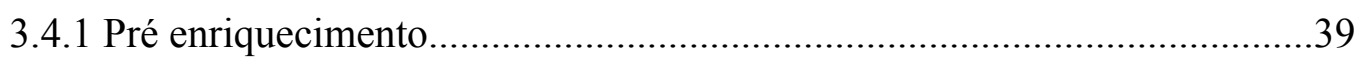

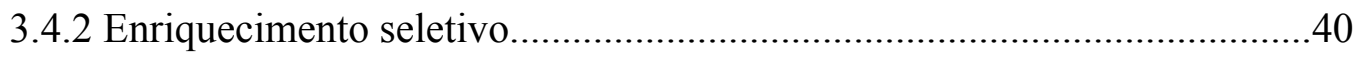

3.4.3 Seleção e isolamento em ágar................................................................40

3.4.4 Prova sorológica de aglutinação rápida..................................................40

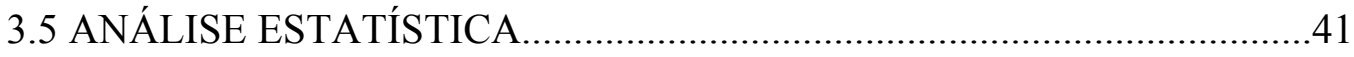

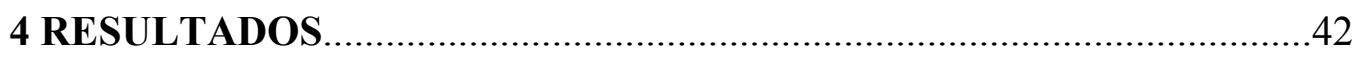

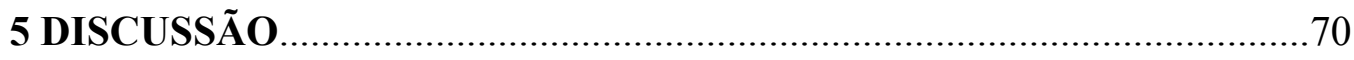

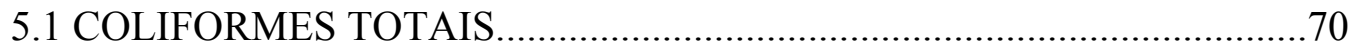

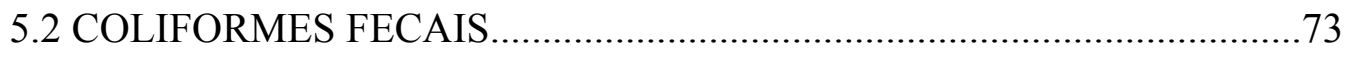




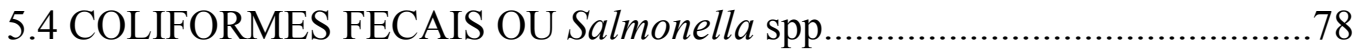

5.5 PRESENÇA DE ANIMAIS, AGRICULTURA E PERÍODOS DO ANO...79

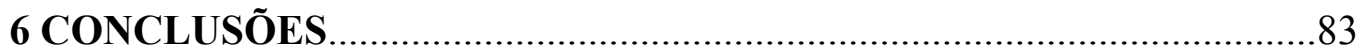

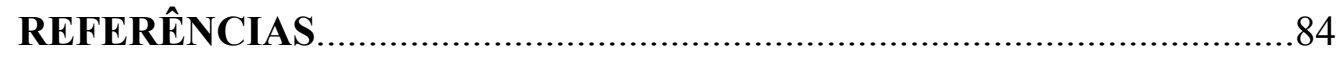




\section{INTRODUÇÃO}

A disponibilidade de água no universo é algo preocupante, o que se evidencia com a presença de grandes desertos e com o abastecimento precário nas grandes cidades. Uma das alternativas de preservação está na reconstrução das matas ciliares, que impedem erosão, manutenção de reservas florestais e o aproveitamento racional da água disponível.

O Brasil é um dos países do mundo que têm na água uma fronteira ainda por explorar, uma economia a ser desenvolvida. A Amazônia, com 1,8\% da água doce do planeta, tem potencial para produzir o dobro das atuais 100 mil toneladas de peixes obtidas na região. A costa brasileira dispõe de $8.400 \mathrm{~km}$ e um limite de 200 milhas exploráveis. Vive-se um paradoxo, ao mesmo tempo em que temos preciosas espécies de peixes com populações em declínio, mantém-se um imenso vazio subaproveitado, apesar de gozar de condições naturais privilegiadas.

Em busca de uma alimentação saudável e com baixos teores calóricos, o consumo de pescado tem aumentado principalmente nas regiões onde há abundância do produto, como cidades costeiras ou banhadas por rios (ALMEIDA, 2002).

A piscicultura é uma atividade em franco desenvolvimento no Brasil. Atualmente observa-se que a atividade se sustenta com a comercialização de peixes vivos destinados à pesca esportiva em pesqueiros comerciais, representando atualmente $90 \%$ da produção. Sendo uma menor parcela, os $10 \%$ restantes, utilizada para a filetagem ou então vendida diretamente às feiras livres, supermercados e à restaurantes ou lanchonetes (ALEXANDRINO, 1999).

A tilápia (Oreochromis spp) é uma das espécies mais procuradas para criações em escala industrial, por apresentar rápido crescimento, grande rusticidade, fácil manejo e alto índice de rendimento. Além disso, possui carne de ótima qualidade, sem espinhos e de bom paladar (GALLI; TORLONI, 1982).

A ocorrência de inadequações de caráter sanitário decorrentes de más práticas de manejo, a falta de treinamento de funcionários, programas de nutrição inadequados, instalações mal projetadas e sub aproveitadas, interferem diretamente com a qualidade microbiológica da água. A utilização indiscriminada de produtos para o controle e prevenção de doenças, muitas vezes sem a prescrição de um médico veterinário sem atentar aos períodos de carência dos princípios ativos e ao impacto que tais terapêuticas 
possam ocasionar no meio ambiente, afeta os peixes, as pessoas, enfim, todo o ecossistema vivo que direta ou indiretamente se relaciona com a produção.

É indispensável portanto a preocupação para que o peixe não sirva de veiculador de perigos, de natureza química, tais como metais pesados, resíduos industriais, ou de natureza biológica, com destaque para agentes patogênicos.

$\mathrm{Na}$ piscicultura, em especial, faz-se necessário destacar que os agentes patogênicos transmitidos pelos peixes para o ser humano, freqüentemente, não causam prejuízos na produção e criação animal. Esta situação acaba não estimulando o produtor a buscar a assistência técnica de um médico veterinário para juntos implementarem um plano de controle sanitário da produção, dificultando intervenções para assegurar a qualidade dos produtos. Pode-se citar como exemplo a infecção de peixes em tanques, por Salmonella spp e alguns agentes do grupo dos coliformes fecais. Estas bactérias não causam doenças perceptíveis nos peixes, mas podem ser patogênicas para o ser humano. Um peixe infectado, poderá quando consumido servir de via de transmissão desses agentes para o ser humano, bem como contaminar outros alimentos e superfícies.

A situação tende a ser mais preocupante em países em desenvolvimento como o Brasil, onde há deficiências de infra-estrutura do setor produtivo e na educação em saúde, agravando esta problemática.

Sabe-se que o controle e a garantia da qualidade e inocuidade dos alimentos não se concentra no processamento industrial, mas sim em cada um dos elos da cadeia produtiva que é responsável por uma parcela de deveres na construção da qualidade final do produto (MENDONÇA; CORREIA; ALBINO, 2002).

$\mathrm{O}$ pescado, além de satisfazer as exigências do consumidor, relativas à aparência, sabor, textura, maciez, suculência, praticidade de preparo e consumo, valor nutricional, disponibilidade no mercado e preço, deve oferecer excelência no aspecto higiênico e sanitário. Isto é, o produto oferecido no mercado deve ser produzido a partir de matérias-primas de boa qualidade, em bom estado de conservação e aprovadas pelos órgãos oficiais de inspeção, ao mesmo tempo em que o processamento deve respeitar boas práticas de fabricação garantindo a máxima qualidade higiênica e sanitária (MENDONÇA; CORREIA; ALBINO, 2002).

Considerando a importância da piscicultura no Brasil, a necessidade e busca de fontes de nutrientes e alimentos mais saudáveis, o crescimento do número de estabelecimentos produtores de pescado na região metropolitana de São Paulo, a ocorrência de inadequações de caráter sanitário, e os riscos da presença de 
microrganismos patogênicos que podem ser veiculados através dos peixes, faz-se necessário um levantamento destes principais agentes microbiológicos, que podem ser causadores de enfermidades no consumidor final dos produtos alimentícios provenientes de piscicultura. Isto como ponto de partida para obter um maior número de informações sobre o risco que esses produtos podem oferecer ao consumidor final e reduzir os riscos de transmissão destes agentes patogênicos através do alimento peixe.

Acredita-se ainda, que com a devida orientação aos piscicultores e outros empresários do setor, a atividade poderá se tornar mais lucrativa, gerando produtos seguros e com qualidade.

Este trabalho é parte integrante do projeto: "Diagnóstico Ecológico-Sanitário de Pesqueiros da Região Metropolitana de São Paulo", que teve por objetivo subsidiar futuras tomadas de decisão relativas ao manejo das propriedades, que auxiliem na sustentabilidade da atividade, tendo sido aprovado “Auxílio à Pesquisa FAPESP”, no processo 01/04081, em nome da Pesquisadora Científica Dra. Katharina Eichbaum Esteves, do Instituto de Pesca do Estado de São Paulo. Participaram deste projeto, pesquisadores do Instituto de Pesca - SP, Instituto de Botânica - SP, Faculdade de Saúde Pública - USP e Faculdade de Medicina Veterinária e Zootecnia - USP.

Diante desta situação o presente projeto teve por objetivos pesquisar a ocorrência de coliformes totais, fecais e a presença de Salmonella spp em tilápias (Oreochromis spp) de pesqueiros da região metropolitana da cidade de São Paulo. 


\section{REVISÃO DA LITERATURA}

\subsection{O PESCADO COMO ALIMENTO}

Um dos maiores desafios deste século continua sendo a produção de alimentos (SANTOS et al., 2002). Segundo estudo divulgado pelo Fundo das Nações Unidas para Assuntos de Populações, a população humana duplica a cada 50 anos. Esta situação implica na necessidade de duplicar também a quantidade de alimentos para que seja, no mínimo, mantido o mesmo estado de nutrição que prevalece hoje no mundo, ou seja, $55 \%$ da população do planeta na iminência da inanição, $20 \%$ em estado de subnutrição e somente 25\% em estado de nutrição (STEMPNIEWSKI, 1986). No Brasil, mais de 50\% da população vive na condição de subnutrição. O consumo de proteínas de alto valor biológico no Brasil é baixo, em torno de $19 \mathrm{~g}$ por dia, enquanto que nos países desenvolvidos, esse índice está em torno de 56g por dia (STEMPNIEWSKI, 1986).

A aquicultura é uma alternativa para incrementar os índices de consumo de proteínas de origem animal e o desenvolvimento socio-econômico de um país. Atualmente, apesar das crises econômicas e do surgimento de novas enfermidades, a aquicultura é considerada um dos sistemas de produção de alimentos que mais cresce no mundo e que poderá contribuir, significativamente, com a crescente demanda mundial de pescado neste milênio (SOUZA, 2002).

A piscicultura vem se mostrando, em todo o mundo, uma alternativa atraente e economicamente sustentável na produção de alimentos de alto valor nutritivo, devido a sua composição em proteínas de alto valor biológico e vitaminas, principalmente a A e a D. Sua composição lipídica é rica em ácidos graxos insaturados e tem baixo teor de colesterol (GERMANO, 2001).

Outro aspecto interessante é que o capital investido na produção de peixes pode oferecer retorno em um prazo bastante reduzido, há casos de um ano. A relação hectare ocupado/ proteína (em quilograma) produzida é no mínimo atraente. Um bovino ocupando um hectare, em três anos, gera aproximadamente de $50 \mathrm{Kg}$ de carne, enquanto que um viveiro de peixes, na mesma área, pode produzir seis toneladas de produto em apenas um ano.

Por outro lado, à medida que o consumidor se desenvolve cultural e economicamente, passa a atuar de forma mais exigente em relação a sua qualidade de vida, consumindo alimentos mais saudáveis e seguros. Essa busca por qualidade 
também é estimulada pela constante oferta de informações fornecidas pela mídia, que alerta sobre os riscos de uma alimentação rica em gorduras saturadas, colesterol e em açúcares (ALMEIDA, 2002).

Neste contexto o pescado ganha uma posição de destaque. É uma importante fonte de nutrientes de alto valor biológico e baixos níveis calóricos (ALMEIDA, 2002). As exigências crescentes no mercado consumidor vêm estimulando o governo e os empresários a investirem cada vez mais no controle e garantia da qualidade destes produtos advindos da piscicultura (SANTOS et al., 2002).

\subsection{AQUICULTURA NO BRASIL}

A produção de pescado no Brasil, na última década, tem se mantido em torno de 750 mil toneladas anuais, com predominância de peixes marinhos. Porém, os estoques naturais vem em franco declínio, pela extração não planejada e pelas alterações bioecológicas como desmatamento, aterros, assoreamentos e sobrepesca. A busca por alternativas vêm colocando em destaque a piscicultura (LIMA; REIS, 2002), o cultivo de peixes em água doce, de forma planejada, é uma alternativa inteligente, ecológica e geradora de alimentos de alto valor nutricional (ALMEIDA et al., 2002).

Segundo Alexandrino (1998), a aquicultura brasileira vem se despontando como um agronegócio, porém com um crescimento desordenado. $\mathrm{O}$ autor afirma que não há o necessário controle sanitário sobre a atividade, o que tem colaborado com a produção de pescado com qualidade duvidosa e gerado sub-aproveitamento do investimento feito pelo produtor em decorrência das altas taxas de mortalidade dos peixes. O planejamento da produção e o acompanhamento técnico veterinário são indispensáveis para a implementação de um programa de sanidade aqüícola na piscicultura garantindo produtividade e produtos seguros para o consumidor.

A piscicultura é uma atividade que vem ganhando força nos últimos anos e está estruturada na comercialização de peixes vivos, destinados à pesca esportiva em pesqueiros comerciais, principal fonte de escoamento desta produção no Brasil. É inegável sua importância na economia local. Além de proporcionar lazer, divulga o produto "peixe" e contribui para a inserção do pescado na alimentação diária das pessoas. Porém ao mesmo tempo em que este segmento se desenvolve como fonte de renda viável, faz-se indispensável a profissionalização das práticas de manejo nutricional, reprodutivo, sanitário e ambiental. 
A comercialização de peixes vivos em pesqueiros comerciais é principal fonte de escoamento desta produção e diferentemente do que ocorre no resto do mundo, estes estabelecimentos recebem cerca de $90 \%$ da produção, sendo o restante distribuído em supermercados, peixarias, indústrias de processamento de filé e vendas direta ao consumidor (ALEXANDRINO, 1999).

Acreditava-se que a produção piscícola atenderia às indústrias processadoras, porém a atividade dos pesqueiros, pagando um preço melhor pelo produto desviou quase que toda a produção, ficando as indústrias processadoras sem condições competitivas. É inegável a contribuição que os pesqueiros propiciam, além do lazer, uma divulgação do produto e consequentemente aumento do consumo e até mudanças nos hábitos alimentares. Porém, faz-se indispensável desenvolver também este setor voltando-se o foco para a qualidade e segurança dos produtos.

A questão não é apenas produzir alimentos, mas assegurar a qualidade dos produtos para o consumidor final (SANTOS et al., 2002). A sobrevivência da indústria de pesca depende da sua capacidade em responder de imediato as exigências presentes e futuras do consumidor e desenvolver novos tipos de produtos (PEIXOTO; SOUSA; MOTA, 2002).

Não obstante, a aquicultura ainda apresenta deficiências em relação à falta de padronização do produto para o consumidor, o que acarreta dificuldades quanto às características de tamanho, sabor, presença ou não de espinhas, forma de preparo e valor nutricional. Entretanto, se o produto tiver boa apresentação como postas ou filés, e embalagem com especificação do produto, torna-se mais fácil o trabalho de marketing e, consequentemente, a colocação do pescado no mercado. Sem dúvida, uma das maiores estratégias utilizadas pelas indústrias de alimentos é explorar a busca por alimentos de qualidade e de fácil preparo (SOUZA, 2002).

A internacionalização de hábitos alimentares fez com que grandes centros como São Paulo oferecessem preparações culinárias originárias de diferentes partes do mundo, podendo-se destacar o consumo crescente de pratos com peixes crus, típicos da culinária japonesa. Este fato exige atenção quanto à qualidade sanitária do produto a ser utilizado, desde a sua produção, uma vez que este não sofrerá processamento térmico antes de ser consumido.

Estes pratos têm sido servidos inclusive nos pesqueiros comerciais onde os peixes, geralmente tilápias, logo após capturados, são preparados e servidos, sem 
controle sanitário, nem inspeção veterinária, não existindo pré tratamento capaz de eliminar microrganismos potencialmente patogênicos presentes.

Perante essas considerações, pode-se afirmar que a piscicultura é um importante segmento econômico em expansão que representa uma importante fonte de proteínas, além de ter uma importância social, por ser uma atividade geradora de empregos. No entanto, a ausência de um controle sanitário adequado pode gerar riscos a saúde da população. É evidente portanto, a necessidade e a importância da implantação de boas práticas de produção e controle zoosanitário, visando preservar a saúde pública, oferecendo alimentos seguros para consumo humano.

\subsection{A TILÁPIA (Oreochromis spp)}

Um dos peixes mais estudados para aproveitamento em criação intensiva em tanques é a tilápia (Oreochromis spp), que foi introduzida no Brasil em 1971 em açudes do nordeste e difundiu-se para todo o país (PROENÇA; BITTENCOURT, 1994). Originária dos rios e lagos africanos é o segundo peixe mais criado no mundo (POPMA; LOVSHIN, 1996). A tilápia é um dos gêneros mais procurados para criações em escala industrial, por apresentar rápido crescimento, grande rusticidade, fácil manejo e alto índice de rendimento, além de possuir carne de boa aceitação e sem espinhos.

A tilapicultura vem se mostrando uma ótima alternativa para a piscicultura de água doce e estuarina. A expansão do cultivo da tilápia, deve-se ao ótimo desempenho, alta rusticidade, facilidade de obtenção de alevinos, adaptabilidade aos mais diversos sistemas de criação, grande aceitação no mercado de lazer (pesqueiros comerciais) e indústrias (MEURER, 2003).

A tilápia tem sido etiquetada como o "novo pescado branco". Esta espécie apresenta os requisitos típicos dos peixes preferidos pelo mercado consumidor, tais como carne branca de textura firme, sabor delicado e fácil filetagem, não tendo espinha em "Y" nem odor desagradável. Além disso, as características que a colocam no pódio das principais espécies cultivadas comercialmente são: a possibilidade de manipulação hormonal do sexo para obtenção dos machos, aceitação de diversos alimentos e capacidade de aproveitar alimentos naturais em viveiros; conversão alimentar entre 1 e 1,6; e resistência a doenças. (SOUZA, 2002)

Jory et al. (2000) relatam que a tilápia tem conquistado espaço no mercado de produtos aquáticos dos Estados Unidos, tanto em volume como na diversidade de 
apresentação (tilápia eviscerada fresca e congelada, inteira e em filé). A prova disso é o aumento na importação ocorrida nos últimos anos, o qual, em peixe inteiro congelado, foi de 12.062 para 21.535 toneladas, e em filé fresco, de 1.460 para 3.590 toneladas, entre os anos de 1995 para 1998. Em 1998 a importação de filé congelado chegou a 2.696 toneladas.

Segundo Castillo (2001), os Estados Unidos, em 2000, importaram 40.469 toneladas de tilápia, sendo 27.781 toneladas de peixe inteiro congelado, 5.185 de filé congelado e 7.501 de filé fresco. O mesmo autor menciona que o consumo de tilápia em 1998 alcançou 50.803 toneladas enquanto que em 2000 chegou a 90.720 toneladas em peso vivo.

Os principais exportadores de tilápia inteira e filé congelado são os países asiáticos, como a Tailândia, Taiwan e Indonésia; e de filé fresco, países latinoamericanos como a Costa Rica, o Equador e Honduras (JORY et al., 2000). Entretanto, existe a expectativa de que o Equador se converta no fornecedor líder de filé fresco de tilápia ao mercado norte-americano, ultrapassando a Costa Rica, onde a produção teve um incremento superior a 10\% ao ano (REDMAYNE, 2000). Em relação ao Brasil, em 1995, a produção de pescado advindo da aquicultura foi ao redor de 27.250 toneladas, o que colocava o Brasil em trigésimo terceiro entre os principais países que praticam a aquicultura, enquanto que a produção anual em 2002 de tilápia, se encontrava entre 30 e 40 mil toneladas (SOUZA, 2002).

A tilápia é uma espécie precoce que apresenta excelente desempenho em diferentes regimes de criação. Em sistemas extensivos, apenas com adubação dos viveiros alcança produtividades de até $3.500 \mathrm{~kg} / \mathrm{ha} / \mathrm{ano}$, em densidades entre $8.000 \mathrm{e}$ 10.000 peixes/ha. Em regimes semi-intensivos, com renovação de água (10 L/seg./ha) e rações de boa qualidade, a tilápia nilótica chega a produzir $15.000 \mathrm{~kg}$ de pescado/ha/ano, em densidades de 20.000 a 30.000 peixes/ha (SOUZA, 2002).

Porém, a ocorrência de inadequações como manejo incorreto, falta de treinamento de funcionários, programas de nutrição inadequados, instalações mal projetadas e sub aproveitadas, afetam diretamente as condições sanitárias da criação, prejudicando a qualidade microbiológica da água, atingindo os peixes e afetando a saúde do consumidor destes produtos, considerando que agentes patogênicos possam estar sendo veiculados durante as diversas etapas da produção. 


\subsection{POLUIÇÃO DAS ÁGUAS E SUA INFUÊNCIA NA QUALIDADE DO PESCADO}

Segundo a Organização Mundial da Saúde, cerca de $80 \%$ de todas as doenças que ocorrem nos países em desenvolvimento são transmitidas por águas contaminadas. A água está presente em quase todas as atividades da vida humana, direta ou indiretamente, por isso o tratamento das águas servidas e o controle da potabilidade são práticas obrigatórias para a manutenção da saúde de uma população e prevenção de doenças. Veiga et al. (2000) relatam que no Brasil, $80 \%$ das doenças e $65 \%$ das internações hospitalares estão relacionadas com o consumo e uso de água não potável e com precárias condições de saneamento básico.

Os alimentos e a água podem servir como veículo de agentes patogênicos ao homem. Microrganismos indicadores de contaminação dos alimentos (coliformes totais e fecais) são geralmente usados para monitorar a qualidade das águas classificando e restringindo seu uso (MÖLLERKE et al., 2002).

Nos países tropicais a maioria das cidades concentra-se no litoral, principalmente às margens dos rios, estuários e na costa, provocando um adensamento populacional desenfreado nestas áreas (CASTRO et al., 2003). O conceito de poluição das águas abrange qualquer alteração por contaminação de esgotos domésticos, resíduos industriais ou acidentes ambientais. No meio aquático qualquer alteração das condições da água resulta em conseqüências significativas nas formas de vida que ali existem, uma vez que esses habitantes dependem e são diretamente influenciados pela temperatura, qualidade química da água, intensidade e concentração de oxigênio das correntezas, concentração de sais, $\mathrm{pH}$, entre outros fatores. A qualidade da água interfere também nos hábitos, tipo de alimentação, no comportamento de peixes e até na sua conformação física (CASTRO et al., 2003). Somado a isto a ocorrência freqüente de catástrofes e acidentes ambientais provocados pelo homem, causam um impacto negativo levando a morte de milhares de peixes em rios e mares, seja pelo desequilíbrio natural ou pela poluição das águas.

A microbiota natural do peixe é relativamente uniforme, porém sofre forte influência das condições físicas, químicas e biológicas da água e das variações de temperatura. A microbiota do peixe vivo está diretamente relacionada à microbiota da água onde ele vive. No muco que recobre a superfície externa do seu corpo, guelras e intestino encontram-se uma ampla variedade de gêneros bacterianos (MÖLLERKE, 
2002). Porém em condições naturais, o pescado recém-capturado não apresenta contaminação por patógenos entéricos ou por indicadores de poluição fecal (CARDOSO; ANDRÉ; SERAFINI, 2003).

O peixe, como qualquer outro animal, logo após a morte sofre uma série de alterações autolíticas e microbianas. As alterações se iniciam pela ação das enzimas que hidrolizam proteínas e oxidam as gorduras. Concomitantemente, ocorre ação microbiana, provocando a degradação dos tecidos e a putrefação (ANDRADE et al., 2002).

A velocidade da deterioração do pescado é influenciada por fatores como: espécie do pescado, grau de exaustão sofrida na captura, natureza e extensão da contaminação microbiana e temperatura de armazenamento (ALVES et al., 2002).

A contaminação primária do pescado pode ser considerada portanto, ocorrente e relevante, gerando conseqüências aos outros pontos da cadeia produtiva como o acondicionamento, transporte, manipulação e comercialização sendo que fatores contribuem marcadamente para o aumento da carga microbiana do pescado. É então de primordial importância a garantia da máxima qualidade do produto nesta elo inicial da cadeia, pois esta microbiota inicial, seja esta deteriorante ou patogênica, é indesejável e prejudicial; a deteriorante pois reduz a vida comercial do produto e a patogênica pois expõe a riscos a saúde do consumidor.

Faz-se concluir que as agressões a natureza aquática ou terrestre a um certo tempo retornará para o próprio homem também como uma forma de agressão, neste caso como alimento (peixe) de baixa qualidade higiênica e sanitária, podendo transmitir doenças leves, moderadas ou graves (SILVA et al., 2002).

\subsection{O PESCADO COMO VIA DE TRANSMISSÃO DE AGENTES PATOGÊNICOS}

A transmissão de agentes patogênicos através do alimento peixe tem sido relatado com maior freqüência (STOSKOPF, 1993). Dentre os fatores que contribuem para esse aumento, inclui-se a capacidade em diagnosticar doenças, o maior reconhecimento dos sintomas, a maior freqüência de exposição a peixes contaminados, o aumento na contaminação de ambientes marinhos e o aumento das populações de alto risco às doenças transmitidas por alimentos.

Em indivíduos imunocompetentes, essas doenças são geralmente auto limitantes, como no caso das gastroenterites, porém, pacientes imunodeprimidos podem sofrer de 
doenças mais graves e até chegar ao óbito, se as condições forem impropriamente diagnosticadas ou quando há uma doença preexistente.

O pescado é um importante veiculador de agentes patogênicos, responsáveis por diversas enfermidades no homem, notadamente as toxinfecções. Podemos classificar os contaminantes presentes no pescado, em microrganismos deteriorantes, microrganismos indicadores de higiene ou de processamento, microrganismos indicadores de manipulação inadequada, microrganismos indicadores de contaminação fecal, microrganismos potencialmente capazes de provocar doenças transmitidas pelo consumo de pescado e microrganismos capazes de liberar toxinas capazes de causar intoxicações ao consumidor. (PIMENTEL; PANETTA, 2003).

Alexandrino (1998), ressalta que a presença dos agentes bacterianos patogênicos, tem sido identificados como os perigos mais freqüentes que comprometem a qualidade dos produtos aqüícolas. A sua ocorrência está relacionada a práticas impróprias de criação, poluição ambiental e hábitos culturais de preparo e consumo do alimento. $\mathrm{O}$ mesmo autor afirma que as maiores perdas na produtividade são causadas por manejo indevido, tais como: má qualidade da água, ração inadequada, falta de cuidados higiênicos com os peixes, com os tanques, com os viveiros e equipamentos e falta de treinamento dos funcionários, favorecendo o aparecimento e disseminação de doenças. Linder et al. (1999) verificando a incidência de microrganismos patogênicos em amostras coletadas de tanques de pesqueiros observaram a ocorrência de Salmonella spp, sugerindo que sistemas de criação intensiva associadas a atividades de lazer podem estar funcionando como fontes disseminadoras importantes.

$\mathrm{Na}$ produção aqüícola uma grande variedade de microrganismos pode ser identificada, sem estar provocando doenças nos peixes. Porém estes peixes podem servir de via de transmissão de agentes patogênicos para o homem, veiculando, por exemplo, agentes como coliformes fecais e Salmonella spp, no caso de peixes criados em locais contaminados por matéria fecal do homem ou de animais. Importa salientar que nos pescados capturados em águas límpidas e não poluídas os únicos microrganismos patogênicos encontrados são o Clostridium botulinum e o Vibrio parahaemolyticcus (ALVES et al., 2002). A presença de outros microrganismos patogênicos se deve à contaminação no manejo do pescado, da produção ou captura à sua comercialização.

Com relação ao tipo de produção, destaque deve ser feito aos consórcios entre peixes e outras criações, como aves e suínos. Nestes sistemas, o uso dos dejetos de aves 
e suínos como fonte de alimentos na piscicultura, tem como vantagem reduzir o problema de poluição ambiental que estes dejetos causam ao meio ambiente, além de ter uma aplicação econômica. Entretanto, a presença de outras espécies animais pode causar contaminação da água e consequentemente dos peixes, com enterobactérias, coliformes e outros agentes patogênicos de origem intestinal, como Salmonella spp (MURATORI, 1994). Piscicultores utilizam, com freqüência, fezes de animais domésticos para fertilizar as águas dos viveiros e produzir algas para alimentação dos peixes. Esse procedimento pode causar aumento da matéria orgânica, favorecendo a multiplicação de bactérias e a diminuição da concentração de oxigênio, podendo causar enfermidades também nos peixes.

Foi relatado por Muratori (2001) mortalidade de tilápias criadas em viveiros com dejetos de suínos. A Edwardsiella tarda foi o agente causal identificado, mostrando o prejuízo que esta prática pode causar aos próprios peixes e o potencial de transmissão destes microrganismos patogênicos para o homem.

Peixes e derivados desempenham importante papel na transmissão de doenças de origem alimentar. Para o controle e prevenção destas doenças o uso de indicadores de contaminação ambiental e fecal, através da enumeração de coliformes totais e fecais e a pesquisa de patogênicos como a Salmonella spp, tem para a saúde pública grande importância, sendo essencial sua detecção para determinação da qualidade do produto (LIMA; REIS, 2002).

Almeida et al. (2002) afirmam que a falta de boas práticas por parte de pescadores e empresários na cadeia produtiva do pescado é fator determinante da contaminação que contribui de forma marcante para baixa qualidade do produto brasileiro, que chega ao consumidor com uma carga microbiana elevada.

Segundo ALVES et al. (2002), as toxinfeções alimentares de origem microbiana tornar-se-ão o mais abrangente problema de saúde pública, com repercussões econômicas amplamente negativas em todo o mundo.

\subsection{COLIFORMES TOTAIS E FECAIS E Salmonella spp}

Os coliformes totais, fecais e Salmonella spp são muito utilizados como indicadores das condições higiênicas e sanitárias de alimentos e tem sido parâmetro freqüentemente utilizado no estudo da qualidade higiênica do pescado, por vários autores em diversos estados do Brasil. Pode-se citar, Agnese et al. (2001) e Andrade et 
al. (2002) no Rio de Janeiro (RJ); Almeida et al. (2002) no Mato Grosso (MT); Aquino et al. (1996) no Amazonas; (AM); Cardoso et al. (2003) em Goiás (GO); Dams et al. (1996) em Santa Catarina (SC); Hoffmann et al. (1999) em São Paulo (SP); Lira et al. (2001) em Alagoas (AL); Mendes et al. (2002) em Pernambuco (PE); Möllerke et al. (2002) no Rio Grande do Sul (RS); Muratori (1994) no Piauí (PI); Nascimento, Filho e Taty (2001) no Maranhão (MA) e Vieira (2000) na Paraíba (PB), entre outros.

O grupo dos coliformes totais inclui todas as bactérias na forma bastonetes Gram negativos, não esporogênicos, aeróbios ou anaeróbios facultativos, capazes de fermentar a lactose com produção de gás em 24 a $48 \mathrm{~h}$ e à temperatura de $35^{\circ} \mathrm{C}$. O habitat dos coliformes é o trato intestinal do homem e de outros animais. Outras enterobactérias podem ser encontrados no meio ambiente ou até em água potável. Fazem parte deste grupo bactérias pertencentes aos gêneros Escherichia, Enterobacter, Citrobacter $e$ Klebsiella. Destes, Citrobacter, Enterobacter e Klebsiella, além de serem encontrados nas fezes, também podem estar presentes em outros ambientes como o solo e vegetais, onde persistem por tempo superior ao de bactérias patogênicas de origem intestinal (FRANCO, 1996).

O grupo dos coliformes fecais correspondem as bactérias pertencentes aos coliformes totais que apresentam a capacidade de continuar fermentando a lactose com produção de gás, sob temperatura de 44 a $45^{\circ} \mathrm{C}$. Nestas condições $90 \%$ dos coliformes fecais encontrados são Escherichia coli (FRANCO, 1996).

O índice de coliformes totais é utilizado para avaliar as condições higiênicas enquanto que índice de coliformes fecais é usado para avaliar a qualidade higiênicosanitária. Coliformes são geralmente usados também como indicadores de deficiência de saneamento (VIEIRA; OLIVEIRA, 2001).

O grupo coliforme é indicador da contaminação de origem fecal, podendo ser pesquisado por meio da técnica de tubos múltiplos que expressa uma estimativa estatística do número de microrganismos presentes na amostra, conhecida como Número Mais Provável (MACHADO et al., 2001). O Número mais povável de coliformes totais e fecais indicam a contaminação de origem ambiental e fecal e indiretamente informa sobre a provável presença de outros patógenos entéricos (LIRA et al., 2001)

Nas carnes, pescado e outros alimentos frescos de origem animal, a maior parte das enterobactérias, advém de contaminação fecal, e sua ocorrência em altas 
concentrações indica especialmente práticas higiênicas inadequadas de manipulação, processamento e armazenamento (LEITÃO, 1995).

Os coliformes fecais não se multiplicam e nem se mantém viáveis na água ambiental por longos intervalos de tempo, devido a baixas concentrações de nutrientes e de temperatura adversa, sendo assim, a sua presença indica uma fonte de contaminação recente (CARDOSO et al., 2001).

Os microrganismos que tem sido isolados com maior freqüência em ambientes marinhos são os coliformes fecais e a Salmonella spp (MENDES et al., 2002). Esses microrganismos relacionam-se diretamente com a cadeia produtiva do peixe pois indicam, a qualidade da água do local de captura.

Apesar de controvérsias com relação aos microrganismos mais representativos da qualidade sanitária de um produto alimentício, os coliformes totais, fecais e a Salmonella spp, tem merecido maior consideração. (ANDRADE et al., 2002).

A salmonelose é considerada um dos mais importantes problemas de saúde pública em todos os países (TESSARI et al., 2003). A Salmonella spp é um dos principais agentes envolvidos nos surtos de toxinfecções alimentares sendo que a maior parte destes estão associados ao consumo de alimentos de origem animal (LIMA; REIS, 2002).

A Salmonella é um microrganismo amplamente difundido na natureza, sendo o homem e animais seus principais reservatórios naturais. Os principais fatores que levaram ao aumento da salmonelose veiculada por alimentos são os procedimentos inadequados de armazenamento, o costume cada vez mais freqüente de comer produtos crus ou insuficientemente aquecidos, o aumento do comércio internacional e a diminuição de resistência às infecções (BARROS; PAVIA; PANETTA, 2002).

O gênero Salmonella inclui duas espécies: Salmonella entéria subdividida em seis subespécies e Salmonella bongori sendo no total, mais de 2.324 sorotipos. Este gênero pertence a família das enterobatériaceas e as principais fontes de infecção são fezes humanas e de animais (TESSARI et al., 2003). A Salmonella spp é uma bactéria que ocorre principalmente em aves e suínos acometendo também ser humano e outros animais. As vias de transmissão incluem a água, solo, insetos, fômites, equipamentos, utensílios utilizados na preparação de alimentos, fezes de animais, carnes cruas de bovino, frango e pescado. Apesar de ser primariamente uma bactéria intestinal, ela pode ser encontrada em efluentes de propriedades rurais, esgoto humano e produtos submetidos a contaminação fecal (TESSARI et al., 2003). 
De acordo com o sorotipo e a espécie animal envolvida o curso da infecção e os dados epidemiológicos variam. Alguns sorotipos são espécie específicos enquanto outros causam doenças em uma ampla variedade de espécies animais (SNOEYENBOS, 1994; WRAY, 1994). Além disso, muitos sorotipos, podem causar infecção alimentar em humanos, trabalhadores que lidam com animais, técnicos de laboratório e veterinários.

Várias espécies de animais domésticos são suscetíveis, sendo que animais jovens, idosos ou em gestação são os de mais alto risco. Segundo Snoeyenbos (1994), outras espécies animais, podem ser infectadas, sem apresentar sinal clínico da doença. Em humanos todas as faixas etárias são suscetíveis, sendo que crianças, idosos e imunocomprometidos uma vez expostos apresentam risco 20 vezes maior que a população em geral e podem ser acometidos por episódios recorrentes. Com relação sintomatologia no homem, as salmoneloses podem produzir gastroenterites, febre, dores de cabeça, dores nos membros, diarréia mucosa, sanguinolenta, dores abdominais, náuseas e vômitos, até quadros clínicos mais severos como as febres entéricas (febres tifóide e paratifóide), afetando mais o homem e outros primatas. A duração dos sintomas é por volta de 1 a 7 dias, iniciando por volta de 12 a 14 horas da ingestão do alimento (BARROS; PAVIA; PANETTA, 2002).

A incidência de Salmonella vem aumentando nos últimos anos, particularmente em alimentos de origem animal, fato que tem preocupado os produtores, as indústrias e os órgãos oficiais de fiscalização (TESSARI et al., 2003). Segundo U.S. FOOD \& DRUG ADMINISTRATION (FDA), é estimado que de 2 a 4 milhões de casos de salmonelose ocorrem nos EUA anualmente.

O maior surto verificado nos Estados Unidos por Salmonella Typhimurium ocorreu em 1985, atingindo oficialmente 200.000 pessoas (BARROS; PAVIA; PANETTA, 2002). Dados do Centers for Disease Control and Prevention (CDC) indicam que anualmente ocorrem 40.000 casos com 500 mortes (BARROS; PAVIA; PANETTA, 2002). O CDC estima ainda que 75\% dos surtos estão associados ao consumo de alimentos crus ou inadequadamente cozidos.

Episódios de salmonelose de origem alimentar associados a viagens aéreas também foram relatadas. (BARROS; PAVIA; PANETTA, 2002) mencionaram que do ano de 1947 até 1984, 23 surtos de toxinfecção alimentar em aeronaves foram registrados nos Estados Unidos, envolvendo vôos de linhas aéreas comerciais. Nestes a Salmonella spp. foi o patógeno mais comum (7 surtos). 
O FDA em um estudo realizado entre 1990 e 1998 observou a freqüência de ocorrência de Salmonella spp em 7,2\% dos produtos de pescado importados (11.312 amostras) e em 1,3\% para o pescado do mercado interno (768 amostras). Aproximadamente $10 \%$ dos importados e $2,8 \%$ do pescado cru do mercado interno foram positivos para Salmonella spp. A incidência em produtos prontos para o consumo em 2.734 produtos analisados, foi de 2,6\%, incluindo, camarão cozido, pasta de peixe, peixe defumado, peixe salgado/seco e caviar.

A distribuição da Salmonella spp em pescado ocorrem com maior incidência no Pacífico central e na África (12\%), sendo menor na Europa e América do Norte (1,6\%) (HEINITZ, 1999).

O Centro de Vigilância Epidemiológica de São Paulo informa a existência de 10 surtos de salmonelose em 1977 (358 casos); 22 surtos em 1998 (472 casos) e 23 surtos (718 casos) em 1999 no estado, não havendo óbitos nos surtos (BARROS; PAVIA; PANETTA, 2002).

Reis (1998), investigando 78 surtos de doenças transmitidas por alimentos no período de 1994 a 1997 em Brasília (DF) identificou como agentes etiológicos mais freqüentes, Salmonella spp (11,6\%) dos casos, B. cereus (7\%), S. aureus $(6,7 \%)$, e Clostridium perfringens (4,7\%). A presença de condições higiênico-sanitárias insatisfatórias ocorreu em 38,4\% das notificações.

Fell (2000) realizou um estudo que mostrou que o consumo de enguia defumada, proveniente de quatro indústrias, foi a via de transmissão de Salmonella spp na Inglaterra no mês de julho de 1998, sendo os animais originários de fazendas de criação na Itália. Segundo Fell (2000), este surto indicou que produtos marinhos podem ser transmissores de salmonelas, mesmo não sendo este um agente naturalmente presente no produto e que o processo de industrialização (por exemplo, a defumação), pode não ser capaz de inativar o agente, uma vez presente.

Taylor (2000) incriminou como causa de um surto de salmonelose acometendo 28 operários de uma obra a água contaminada do tanque de abastecimento, o que foi comprovado posteriormente confirmado por investigação epidemiológica.

Fernández (1996), estudou a contaminação de pescado por Salmonella spp em 89 pontos de comércio fixos e ambulantes da cidade de Guadalajara, México, encontrando o agente em 16\% das 221 amostras estudadas. Carrera (1998) em Cuba observou que a maioria das ocorrências de surtos por salmonelas entre 1995 e 1997, foram causados por alimentos semi elaborados cárneos $(11 \%)$ e de pescado $(10 \%)$. Na 
Austrália O`Grady e Krause (1999), relataram um surto causado pelo consumo de carne cozida de tartaruga marinha (Chelonia midas) atingindo 36 pessoas, em setembro de 1998. Tsuji e Hamada (1999) no Japão, descreveram um surto causado por salgadinhos à base de peixe, em maio de 1998. O agente foi isolados no alimento incriminado na cidade de Himeji e 16 cidades próximas.

O impacto econômico causado por estes surtos é considerável. Segundo um estudo realizado por Lopalco (2000), na Universidade de Bari, a salmonelose é uma das doenças mais freqüentes transmitidas por alimentos e o custo estimado de um caso está em torno de US\$ 74 (para pacientes não hospitalizados) e US\$ 1.896 (para pacientes hospitalizados).

No Brasil, tem sido observado significativo aumento no número de surtos por Salmonella spp desde 1994. Na grande São Paulo foram relatados no período de outubro de 1994 a junho de 1997, 18 surtos envolvendo 23 tipos diferentes de alimentos, predominantemente de origem animal, sendo a Salmonella spp o agente causal identificado em 13 (72,2\%) destes surtos. (JAKABI, 1999).

O monitoramento de microrganismos permite identificar a ocorrência de procedimentos inadequados que podem comprometer a qualidade dos alimentos, permitindo o controle e redução de riscos à saúde do consumidor, além de auxiliar no desenvolvimento de condições higiênico-sanitárias propiciando a obtenção de alimentos mais saudáveis (ALVES et al., 2002).

Considerando a importância da piscicultura em São Paulo, o aumento do número de pesqueiros comerciais, a necessidade e busca crescente de alimentos saudáveis e nutritivos, a ausência de controle sanitário na produção e os riscos da presença de microrganismos patogênicos, que podem ser veiculados através desta produção, o presente trabalho teve por objetivo pesquisar a ocorrência de coliformes totais, fecais e a presença de Salmonella spp em tilápias de pesqueiros da região metropolitana da São Paulo. 


\section{MATERIAL(IS) E MÉTODO(S)}

Os trabalhos foram realizados em 30 pesqueiros da região metropolitana de São Paulo. Estes pesqueiros foram selecionados por uma amostragem randômica estratificada, realizada a partir de uma lista de pesqueiros localizados na região metropolitana de São Paulo. Estes 30 pesqueiros, situados na região metropolitana de São Paulo, foram escolhidos seguindo dois critérios: localização e categoria. Em relação a localização, escolheu-se municípios situados em diferentes eixos da região metropolitana de São Paulo. Em relação a categoria, os pesqueiros da listagem inicial foram previamente agrupados em quatro categorias (A, B, C, D), de acordo com Esteves et al., (2003).

Os pesqueiros foram codificados de acordo com a seqüência e período de colheita numerados e denominados de 1 a 30, para o período seco e frio (SE), e para o período chuvoso e quente $(\mathrm{CH})$.

O primeiro período de colheita de amostras ocorreu entre setembro e outubro de 2001 (SE) e o segundo entre fevereiro e março de 2002 (CH).

Para localizar os pesqueiros foi feito o georreferenciamento das propriedades, utilizando-se GPS (Sistema de Posicionamento Geográfico, GARMIN modelo II plus). A partir das coordenadas e da altitude obtidas, os pesqueiros foram localizados em carta base da EMPLASA, escala de 1: 100 0000, edição de 1980 (ESTEVES et al., 2003). 
Figura 1 - Localização dos 30 pesqueiros estudados na região metropolitana de São Paulo - São Paulo - set 2001 out 2001/fev 2002 - mar 2002. Fonte: (ESTEVES et al., 2003).

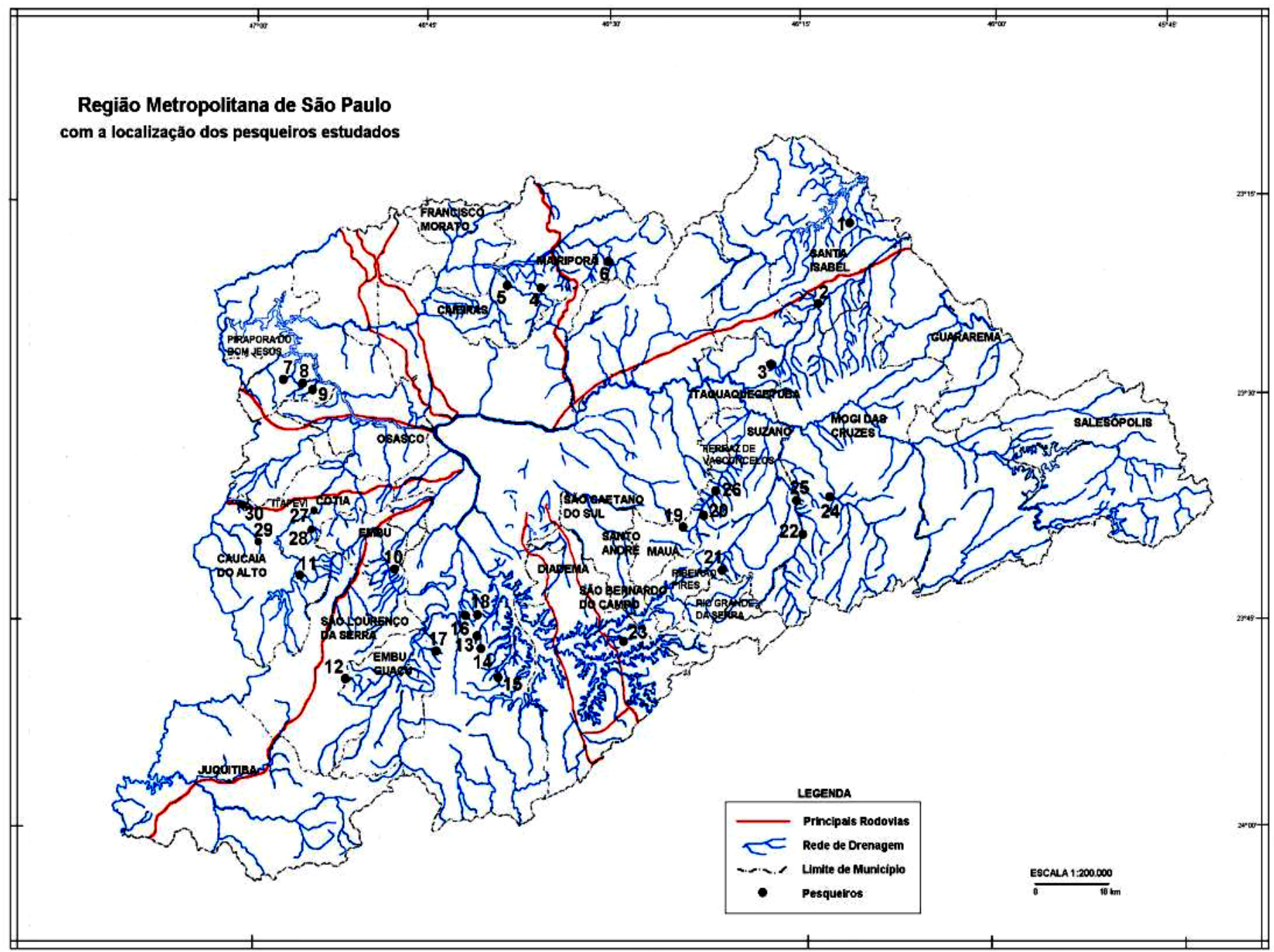


A caracterização do entorno foi feita através da observação das características da paisagem local, no momento da coleta. Atentou-se principalmente para presença de cultivos agrícolas e presença de criação de animais.

Os 30 pesqueiros foram visitados nos dois diferentes períodos e foram colhidas três amostras de cada um deles no período seco e frio e outras três amostras no período chuvoso e quente.

Cada uma das amostras foi representada por dois peixes, isto é, foram colhidas duas unidades, sob as mesmas condições, no mesmo momento e acondicionadas em uma mesma embalagem. Esse procedimento foi feito para facilitar a enumeração de coliformes totais e fecais e a pesquisa de presença de Salmonella spp. Foram estudados no total, 12 exemplares (seis amostras) de tilápias (Oreochromis spp) de cada um dos pesqueiros.

O transporte aos locais de colheita das amostras foi realizado por carros oficiais do Instituto de Pesca - SP, juntamente com as outras frentes do projeto constituídas por pesquisadores do Instituto de Pesca - SP, Faculdade de Saúde Pública - USP e Instituto de Botânica - SP. Foram realizadas de forma geral, duas saídas por semana, sendo que em cada uma destas saídas se realizava colheita em dois ou três pesqueiros.

Os peixes foram colhidos com o auxílio de tarrafas e retirados das mesmas com o máximo cuidado para não contaminar a amostra, não permitindo o contato dos mesmos com mãos de manipuladores. Foram colocados em sacos plásticos, estéreis, dois a dois, e acondicionados em caixas isotérmicas, mantidas resfriadas com auxílio de gelo químico até a chegada ao laboratório.

As amostras foram levadas para o Laboratório do Setor de Higiene Alimentar do Departamento de Medicina Veterinária Preventiva e Saúde Animal da Faculdade de Medicina Veterinária e Zootecnia da Universidade de São Paulo, acompanhadas de ficha de colheita com as seguintes informações: descrição da amostra, localização da colheita, data e horário da colheita, responsável pela colheita, tipo de acondicionamento da amostra, responsável pela propriedade, endereço, telefone para contato e tipos de exames a serem realizados.

As análises laboratoriais seguiram a metodologia do Laboratório Nacional de Referência Animal (LANARA, 1991/1992). As amostras foram preparadas para as análises pela técnica da lavagem superficial. 


\subsection{TÉCNICA DA LAVAGEM SUPERFICIAL}

Escolheu-se a técnica de lavado superficial descrita por Silva et al. (1997) modificada, considerando que o peixe alberga uma infinidade de microrganismos principalmente sobre a pele, guelras e trato intestinal (ALMEIDA et al., 2002) e que após sua morte é esta microbiota que invade tecidos internos como musculatura (Martins; Vaz; Minozzo, 2002). Segundo Liuson et al. (2002) a técnica da lavagem superficial mostra-se prática e satisfatória, oferece baixo risco de contaminação pela manipulação para a retirada da alíquota analítica, maximizando a detecção dos agentes patogênicos, pelo aumento da superfície estudada e maior desprendimento dos microrganismos. Esta técnica é indicada por Silva et al. (1997) e pelo Manual LANARA (1991/1992) para carcaças de aves inteiras, camarões, peixes, grãos, sementes, folhas e superfícies de embalagens.

\subsection{PRÉ-PREPARO DAS AMOSTRAS PARA ANÁLISE}

No laboratório, de cada amostra, contendo dois peixes, um foi adicionado em um saco plástico estéril contendo em $225 \mathrm{~mL}$ de água peptonada a $0,1 \%$ para a pesquisa de coliformes totais e fecais e outro em um saco plástico estéril contendo $225 \mathrm{~mL}$ de água peptonada a 1,0\% para a pesquisa de Salmonella spp. Cada um dos sacos foi massageado externamente, durante um minuto, tomando-se os devidos cuidados para que pontas ou protuberâncias não viessem a furar a embalagem. Utilizou-se o volume fixo de $225 \mathrm{ml}$ do diluente independentemente do peso da amostra. Os sacos plásticos estéreis foram tarados e os peixes pesados.

$\mathrm{Na}$ enumeração de coliformes totais e fecais optou-se pela expressão dos resultados em NMP/grama de peixe. Para tanto converteu-se o NMP obtido por mililitro de água de lavagem em NMP por grama de amostra. Se a diluição fosse 1:1, cada ml de lavado corresponderia a $1,0 \mathrm{~g}$ de amostra e o valor $\mathrm{NMP} / \mathrm{g}$ seria igual ao valor obtido por ml. Como a diluição foi diferente de 1:1, primeiro foi calculado a quantos gramas de amostra corresponderia 1,0 ml de lavado. Por exemplo, um peixe de $675 \mathrm{~g}$ com $225 \mathrm{ml}$ de diluente, cada $\mathrm{ml}$ de lavado, corresponde a $3 \mathrm{~g}$ de amostra. Neste caso, o NMP/g de amostra, é igual ao NMP/ml de lavado, dividido por 3 (SILVA et al., 1997). A fórmula abaixo permite a conversão do resultado expresso em $\mathrm{NMP} / \mathrm{ml}$ para $\mathrm{NMP} / \mathrm{g}$. Isto é, o valor do resultado expresso em NMP/g é igual ao valor do NMP/ml multiplicado pelo 
volume de diluente fixo para todas as amostras $(225 \mathrm{ml})$ dividido pelo peso de cada amostra (peixe) em gramas.

$$
\mathrm{NMP} / \mathrm{g}=\frac{\mathrm{NMP} / \mathrm{ml} \times 225 \mathrm{~mL}}{\text { Peso da amostra }(\mathrm{g})}
$$

\subsection{ENUMERAÇÃO DE COLIFORMES TOTAIS E FECAIS EM NMP/g}

A partir do lavado superficial foram feitas dez diluições: $10^{-1}, 10^{-2}, 10^{-3}$ até $10^{-}$ ${ }^{10}$. Foi semeado $1 \mathrm{~mL}$ de cada diluição em cada uma das séries de três tubos da diluição de caldo lauril sulfato com tubo de Duhran e incubados por $48 \mathrm{~h}$. sob temperatura entre 35 e $37^{\circ} \mathrm{C}$.

De cada um dos tubos considerados como positivos, onde houve turvação e formação de gás, foi feita a semeadura em placas de ágar Levine, incubadas em estufa com temperatura entre 35 e $37^{\circ} \mathrm{C}$ por $48 \mathrm{~h}$. O aparecimento de colônias confirmaram a presença de coliformes totais.

Dos mesmos tubos considerados positivos foi semeado um tubo contendo caldo bile verde brilhante (BVB) e outro com caldo triptona, incubados em banho-maria a $44,5^{\circ} \mathrm{C}$, por $48 \mathrm{~h}$. A turvação e produção de gás nos tubos de BVB e a formação de anel vermelho no caldo triptona, após a adição de $0,3 \mathrm{ml}$ do reativo de Kovacs confirmaram a presença de coliformes fecais.

O NMP de coliformes totais e fecais foi obtido pela tabela de NMP - Número Mais Provável de Coliformes, de acordo com os Métodos de Análise Microbiológica para Alimentos, do Ministério da Agricultura, do Abastecimento e da Reforma Agrária, 1991/1992 - $2^{\circ}$ revisão.

\subsection{PESQUISA DE Salmonella spp}

\subsubsection{Pré enriquecimento}

O pré-enriquecimento foi realizado incubando-se o saco plástico contendo o lavado, sem o peixe, sob temperatura entre 35 e $37^{\circ} \mathrm{C}$, durante $24 \mathrm{~h}$. 


\subsubsection{Enriquecimento seletivo}

Decorrido o pré-enriquecimento pipetou-se $1 \mathrm{~mL}$ da solução em $10 \mathrm{~mL}$ de caldo selenito cistina (SC), adicionou-se $0,1 \mathrm{ml}$ de novabiocina e incubou-se em banho-maria à $43^{\circ} \mathrm{C}$, por $24 \mathrm{~h}$. Outro $1 \mathrm{~mL}$ da solução foi transferido para $10 \mathrm{~mL}$ de caldo tetrationato (TT), acrescido de $0,1 \mathrm{~mL}$ de novabiocina, $0,1 \mathrm{~mL}$ de verde brilhante e $0,2 \mathrm{~mL}$ de iodo em solução a $20 \%$, incubado em banho-maria à $43^{\circ} \mathrm{C}$, por $24 \mathrm{~h}$.

\subsubsection{Seleção e isolamento em ágar}

Após o enriquecimento seletivo, o material de cada caldo foi semeado com alça de platina em ágar BVB e ágar Salmonella-Shigella (SS), e incubados na temperatura de 35 a $37^{\circ} \mathrm{C}$ por $24 \mathrm{~h}$.

As colônias suspeitas, de coloração vermelha, foram repicadas das placas de ágar BVB e ágar SS e semeadas em meio triplice sugar iron (TSI) em picada em profundidade (coluna vertical) e em estrias na superfície; incubando à $35^{\circ} \mathrm{C}$ por $24 \mathrm{~h}$. As colônias suspeitas do meio TSI apresentaram alterações no meio de cultura com produção de gás, precipitado preto de $\mathrm{H}_{2} \mathrm{~S}$, vermelho na superfície e amarelo no fundo em anaerobiose.

\subsubsection{Prova sorológica de aglutinação rápida}

Foi preparada uma suspensão bacteriana pipetando-se $0,5 \mathrm{~mL}$ de solução salina estéril a $0,85 \%$ nos tubos de TSI. Com auxílio de pipeta Pasteur foram depositadas duas gotas da suspensão em uma lâmina de vidro e adicionada a esta suspensão uma gota do soro anti-Salmonella polivalente "O” (Samonella-polivalente somático®) sendo feita a homogeneização e leitura imediata. Em paralelo foi feito um teste controle do reagente, utilizando-se uma gota do soro polivalente com solução salina, para descartar reações de auto-aglutinação. O resultado foi considerado positivo quando houve aglutinação na mistura da suspensão-teste com o soro anti-Salmonella e não houve aglutinação no controle. $\mathrm{O}$ resultado foi considerado negativo quando não ocorreu aglutinação em ambas as misturas. 


\subsection{ANÁLISE ESTATÍSTICA}

Os dados obtidos foram tratados estatisticamente para se verificar a associação entre a ocorrência de coliformes fecais ou de Salmonella spp nos peixes de pesqueiros da região metropolitana de São Paulo e os dois períodos estudados: seco e frio, quente e chuvoso. Os dados obtidos foram também analisados estatisticamente para verificar a associação entre a ocorrência de coliformes fecais ou de Salmonella spp nos peixes e a presença ou ausência de animais ou agricultura nos pesqueiros estudados. Foram utilizados os testes estatísticos de Qui Quadrado, programa EPI INFO, CDC, USA, versão 6 e de Fischer, programa STAT XACT-3. Adotou-se nível de significância $\mathrm{p}<0,05$ (NORMAN; STREINER, 1994). 


\section{RESULTADOS}

Os dados obtidos foram tabulados, e os resultados agrupados de acordo com as categorias de informações levantadas. Foi realizada análise exploratória dos dados, buscando-se possíveis correlações entre as características dos sistemas produtivos e a situação microbiológica encontrada nas análises realizadas. Para cada aspecto estudado os resultados foram tabulados e apresentados em tabelas e gráficos.

Os resultados, obtidos das 180 amostras, sendo 90 amostras no período seco e frio (SE) e 90 no período chuvoso e quente $(\mathrm{CH})$, foram expressos em Número Mais Provável por grama $(\mathrm{NMP} / \mathrm{g})$ de coliformes totais e de coliformes fecais e presença de Salmonella spp em presença ou ausência e estão apresentados nas tabelas de número $1 \mathrm{a}$ 20.

Observa-se na Tabela 1 que as amostras apresentaram, durante o período seco e frio, resultados com variações de $<0,3$ a $4,6 \times 10^{7} \mathrm{NMP} / \mathrm{g}$, e na Tabela 2 , durante $\mathrm{o}$ período chuvoso e quente, variações de $<0,9$ a $1,7 \times 10^{7} \mathrm{NMP} / \mathrm{g}$.

O sinal de $<$ indica que o valor obtido como resultado está abaixo do limite mínimo de detecção do teste utilizado. 
Tabela 1 - Número mais provável por grama de coliformes totais das amostras analisadas durante o período seco e frio (SE) em pesqueiros da região metropolitana de São Paulo - São Paulo set 2001 - out 2001

\begin{tabular}{|c|c|c|c|}
\hline PESQUEIRO & AMOSTRA 1 & AMOSTRA 2 & $\overline{\text { AMOSTRA } 3}$ \\
\hline $1 \mathrm{SE}$ & $<0,3$ & $<0,5$ & $<0,4$ \\
\hline 2SE & $7,8 \times 10^{3}$ & $7,8 \times 10^{3}$ & $7,8 \times 10^{3}$ \\
\hline $3 \mathrm{SE}$ & $7,8 \times 10^{3}$ & $7,8 \times 10^{3}$ & $7,8 \times 10^{3}$ \\
\hline 4SE & $3,1 \times 10$ & $4,0 \times 10$ & $1,2 \times 10^{3}$ \\
\hline 5SE & $2,4 \times 10^{2}$ & $5,8 \times 10^{3}$ & $4,5 \times 10^{3}$ \\
\hline 6SE & $1,2 \times 10^{3}$ & $2,2 \times 10^{3}$ & $1,3 \times 10^{3}$ \\
\hline 7SE & $3,6 \times 10^{2}$ & $4,5 \times 10^{3}$ & $1,1 \times 10^{3}$ \\
\hline 8SE & $1,5 \times 10^{3}$ & $8,5 \times 10^{4}$ & $1,1 \times 10^{5}$ \\
\hline 9SE & $5,4 \times 10^{2}$ & $6,0 \times 10^{4}$ & $1,6 \times 10^{4}$ \\
\hline 10SE & $9,4 \times 10$ & $2,5 \times 10^{2}$ & $1,9 \times 10^{3}$ \\
\hline $11 \mathrm{SE}$ & $3,6 \times 10$ & $2,8 \times 10^{2}$ & $3,8 \times 10^{2}$ \\
\hline $12 \mathrm{SE}$ & 3,1 & $2,3 \times 10$ & $1,2 \times 10^{2}$ \\
\hline $13 \mathrm{SE}$ & $1,7 \times 10$ & $4,0 \times 10^{3}$ & $4,8 \times 10^{3}$ \\
\hline 14SE & $6,5 \times 10^{4}$ & $1,5 \times 10^{4}$ & $1,8 \times 10^{5}$ \\
\hline $15 \mathrm{SE}$ & $2,0 \times 10^{3}$ & $5,0 \times 10^{4}$ & $1,4 \times 10^{4}$ \\
\hline $16 \mathrm{SE}$ & $1,5 \times 10^{5}$ & $6,9 \times 10^{5}$ & $7,9 \times 10^{5}$ \\
\hline $17 \mathrm{SE}$ & $1,6 \times 10^{2}$ & $1,7 \times 10^{4}$ & $1,1 \times 10^{4}$ \\
\hline 18SE & $3,1 \times 10^{4}$ & $3,0 \times 10^{6}$ & $4,6 \times 10^{7}$ \\
\hline 19SE & $4,1 \times 10^{3}$ & $8,8 \times 10^{3}$ & $3,8 \times 10^{6}$ \\
\hline 20SE & $8,8 \times 10^{3}$ & $7,6 \times 10^{4}$ & $7,8 \times 10^{4}$ \\
\hline $21 \mathrm{SE}$ & $3,0 \times 10^{3}$ & $3,3 \times 10^{4}$ & $1,4 \times 10^{5}$ \\
\hline 22SE & $9,6 \times 10^{4}$ & $5,9 \times 10^{5}$ & $3,7 \times 10^{6}$ \\
\hline 23SE & $4,2 \times 10^{2}$ & $1,1 \times 10^{4}$ & $1,4 \times 10^{4}$ \\
\hline 24SE & $1,4 \times 10^{3}$ & $2,0 \times 10^{3}$ & $1,3 \times 10^{4}$ \\
\hline $25 \mathrm{SE}$ & $8,3 \times 10$ & $2,2 \times 10^{2}$ & $7,7 \times 10^{2}$ \\
\hline 26SE & $5,1 \times 10$ & $1,3 \times 10^{2}$ & $1,0 \times 10^{2}$ \\
\hline $27 \mathrm{SE}$ & $3,0 \times 10^{4}$ & $6,5 \times 10^{5}$ & $9,0 \times 10^{5}$ \\
\hline 28SE & $2,0 \times 10^{2}$ & $8,7 \times 10^{3}$ & $2,5 \times 10^{5}$ \\
\hline 29SE & $8,6 \times 10^{3}$ & $1,2 \times 10^{5}$ & $1,6 \times 10^{6}$ \\
\hline 30SE & $1,8 \times 10^{2}$ & $2,7 \times 10^{2}$ & $3,6 \times 10^{4}$ \\
\hline
\end{tabular}


Tabela 2 - Número mais provável por grama de coliformes totais das amostras analisadas durante o período chuvoso e quente $(\mathrm{CH})$ em pesqueiros da região metropolitana de São Paulo - São Paulo - fev 2002 - mar 2002

\begin{tabular}{|c|c|c|c|}
\hline PESQUEIRO & AMOSTRA 1 & AMOSTRA 2 & AMOSTRA 3 \\
\hline $1 \mathrm{CH}$ & $7,5 \times 10^{2}$ & $6,3 \times 10^{3}$ & $3,7 \times 10^{3}$ \\
\hline $2 \mathrm{CH}$ & $6,2 \times 10^{2}$ & $2,4 \times 10^{3}$ & $2,4 \times 10^{4}$ \\
\hline $3 \mathrm{CH}$ & $7,6 \times 10^{2}$ & $2,1 \times 10^{4}$ & $1,6 \times 10$ \\
\hline $4 \mathrm{CH}$ & $3,3 \times 10^{3}$ & $1,0 \times 10^{2}$ & $2,0 \times 10^{4}$ \\
\hline $5 \mathrm{CH}$ & $2,7 \times 10^{5}$ & $5,5 \times 10^{5}$ & $1,3 \times 10^{5}$ \\
\hline $6 \mathrm{CH}$ & $5,2 \times 10$ & $1,7 \times 10^{3}$ & $4,9 \times 10^{2}$ \\
\hline $7 \mathrm{CH}$ & $3,9 \times 10^{2}$ & $1,2 \times 10^{2}$ & $6,6 \times 10$ \\
\hline $8 \mathrm{CH}$ & $1,1 \times 10^{3}$ & $6,2 \times 10^{2}$ & $1,6 \times 10^{4}$ \\
\hline $9 \mathrm{CH}$ & $3,1 \times 10^{2}$ & $8,0 \times 10^{3}$ & $6,3 \times 10$ \\
\hline $10 \mathrm{CH}$ & $4,5 \times 10^{3}$ & $1,2 \times 10^{4}$ & $1,8 \times 10^{4}$ \\
\hline $11 \mathrm{CH}$ & $2,2 \times 10^{4}$ & $2,0 \times 10^{5}$ & $3,5 \times 10^{2}$ \\
\hline $12 \mathrm{CH}$ & $1,2 \times 10^{3}$ & $5,6 \times 10^{3}$ & $4,7 \times 10^{3}$ \\
\hline $13 \mathrm{CH}$ & $5,8 \times 10^{3}$ & $5,8 \times 10^{2}$ & $1,7 \times 10^{7}$ \\
\hline $14 \mathrm{CH}$ & $7,3 \times 10^{3}$ & $4,6 \times 10^{5}$ & $7,3 \times 10^{2}$ \\
\hline $15 \mathrm{CH}$ & $4,7 \times 10^{3}$ & $3,7 \times 10^{4}$ & $1,5 \times 10^{4}$ \\
\hline $16 \mathrm{CH}$ & 7,6 & $1,1 \times 10$ & 9,0 \\
\hline $17 \mathrm{CH}$ & $6,1 \times 10^{5}$ & $8,3 \times 10$ & $2,7 \times 10^{4}$ \\
\hline $18 \mathrm{CH}$ & $1,2 \times 10^{4}$ & $1,1 \times 10^{2}$ & $1,0 \times 10^{3}$ \\
\hline $19 \mathrm{CH}$ & $1,8 \times 10$ & $1,1 \times 10^{3}$ & $3,5 \times 10^{4}$ \\
\hline $20 \mathrm{CH}$ & $3,1 \times 10^{3}$ & $1,5 \times 10^{4}$ & $9,4 \times 10^{3}$ \\
\hline $21 \mathrm{CH}$ & $4,0 \times 10^{2}$ & 6,1 & $3,2 \times 10^{2}$ \\
\hline $22 \mathrm{CH}$ & $9,8 \times 10^{3}$ & $4,1 \times 10^{3}$ & $3,3 \times 10^{3}$ \\
\hline $23 \mathrm{CH}$ & $2,4 \times 10^{2}$ & $4,7 \times 10^{3}$ & $2,6 \times 10^{3}$ \\
\hline $24 \mathrm{CH}$ & $5,8 \times 10^{3}$ & $1,4 \times 10^{5}$ & $2,7 \times 10^{3}$ \\
\hline $25 \mathrm{CH}$ & $1,2 \times 10$ & $9,8 \times 10^{2}$ & $4,7 \times 10^{3}$ \\
\hline $26 \mathrm{CH}$ & $2,7 \times 10^{2}$ & $2,5 \times 10^{4}$ & $1,9 \times 10^{3}$ \\
\hline $27 \mathrm{CH}$ & $1,7 \times 10$ & $<1,9$ & 2,8 \\
\hline $28 \mathrm{CH}$ & $5,2 \times 10^{4}$ & $8,8 \times 10^{4}$ & $1,1 \times 10^{5}$ \\
\hline $29 \mathrm{CH}$ & $5,2 \times 10^{2}$ & $1,6 \times 10^{2}$ & $2,6 \times 10$ \\
\hline $30 \mathrm{CH}$ & $<1,34$ & $<1,8$ & $<0,9$ \\
\hline
\end{tabular}


A Tabela 3 distribui as 180 amostras analisadas nos períodos seco e frio; chuvoso e quente e em ambos, de acordo com os resultados obtidos em NMP/g de coliformes totais, em intervalos de um ciclo logarítmico. Observa-se que 62 (68,9\%) amostras no período frio e seco; $63(70,0 \%)$ amostras no período chuvoso e quente e $125(69,4 \%)$ em ambos os períodos se concentraram entre $10^{2}$ e $10^{5} \mathrm{NMP} / \mathrm{g}$.

No período seco e frio, 16 amostras $(17,8 \%)$ apresentaram contagens $>10^{5} ; 62$ $(68,9 \%)$ apresentaram contagens $>10^{3} ; 86(95,6 \%)$ apresentaram contagens $>10^{1}$, no período chuvoso e quente, nove amostras $(10,0 \%)$ apresentaram contagens $>10^{5} ; 52$ $(57,8 \%)$ apresentaram contagens $>10^{3}$ e $82(91,1 \%)$ apresentaram contagens $>10^{1}$ e em ambos os períodos 25 amostras $(13,9 \%)$ apresentaram contagens $>10^{5} ; 114(63,3 \%)$ apresentaram contagens $>10^{3} ; 168(93,3 \%)$ apresentaram contagens $>10^{1}$ (Tabela 3 ). 
Tabela 3 - Distribuição das amostras colhidas durante os períodos seco e frio (SE); chuvoso e quente $(\mathrm{CH})$ de acordo com a ocorrência de coliformes totais em NMP/g apresentados em intervalos de um ciclo logarítmico, em pesqueiros da região metropolitana de São Paulo - São Paulo - set 2001 - out 2001/fev 2002 - mar 2002

\begin{tabular}{|c|c|c|c|c|c|c|}
\hline \multirow[t]{4}{*}{$\mathrm{NMP} / \mathrm{g}$} & \multirow{2}{*}{\multicolumn{2}{|c|}{$\begin{array}{c}\text { PERÍODO } \\
\text { SECO E FRIO }\end{array}$}} & \multirow{2}{*}{\multicolumn{2}{|c|}{$\begin{array}{c}\text { PERÍODO } \\
\text { QUENTE E CHUVOSO }\end{array}$}} & \multirow{2}{*}{\multicolumn{2}{|c|}{$\begin{array}{c}\text { PERÍODO } \\
\text { SECO E FRIO E QUENTE E } \\
\text { CHUVOSO }\end{array}$}} \\
\hline & & & & & & \\
\hline & N. & $\%$ & N. & $\%$ & N. & $\%$ \\
\hline & AMOSTRAS & AMOSTRAS & AMOSTRAS & AMOSTRAS & AMOSTRAS & AMOSTRAS \\
\hline$<10$ & 4 & $4,4 \%$ & 8 & $8,9 \%$ & 12 & $6,7 \%$ \\
\hline $10-10^{2}$ & 8 & $8,9 \%$ & 10 & $11,1 \%$ & 18 & $10,0 \%$ \\
\hline $10^{2-} 10^{3}$ & 16 & $17,8 \%$ & 20 & $22,2 \%$ & 36 & $20,0 \%$ \\
\hline $10^{3-} 10^{4}$ & 27 & $30,0 \%$ & 27 & $30,0 \%$ & 54 & $30,0 \%$ \\
\hline $10^{4-} 10^{5}$ & 19 & $21,1 \%$ & 16 & $17,8 \%$ & 35 & $19,4 \%$ \\
\hline $10^{5-10^{6}}$ & 11 & $12,2 \%$ & 8 & $8,9 \%$ & 19 & $10,6 \%$ \\
\hline $10^{6-10^{7}}$ & 4 & $4,4 \%$ & 0 & $0,0 \%$ & 4 & $2,2 \%$ \\
\hline $10^{7-}-10^{8}$ & 1 & $1,1 \%$ & 1 & $1,1 \%$ & 2 & $1,1 \%$ \\
\hline TOTAL & 90 & $100,0 \%$ & 90 & $100,0 \%$ & 180 & $100,0 \%$ \\
\hline
\end{tabular}

Figura 2 - Distribuição, em porcentagem, das 180 amostras colhidas durante os períodos seco e frio (SE); chuvoso e quente $(\mathrm{CH})$ de acordo com a ocorrência de coliformes totais em NMP/g apresentados em intervalos de um ciclo logarítmico, em 30 pesqueiros da região metropolitana de São Paulo - São Paulo - set 2001 - out 2001/fev 2002 - mar 2002

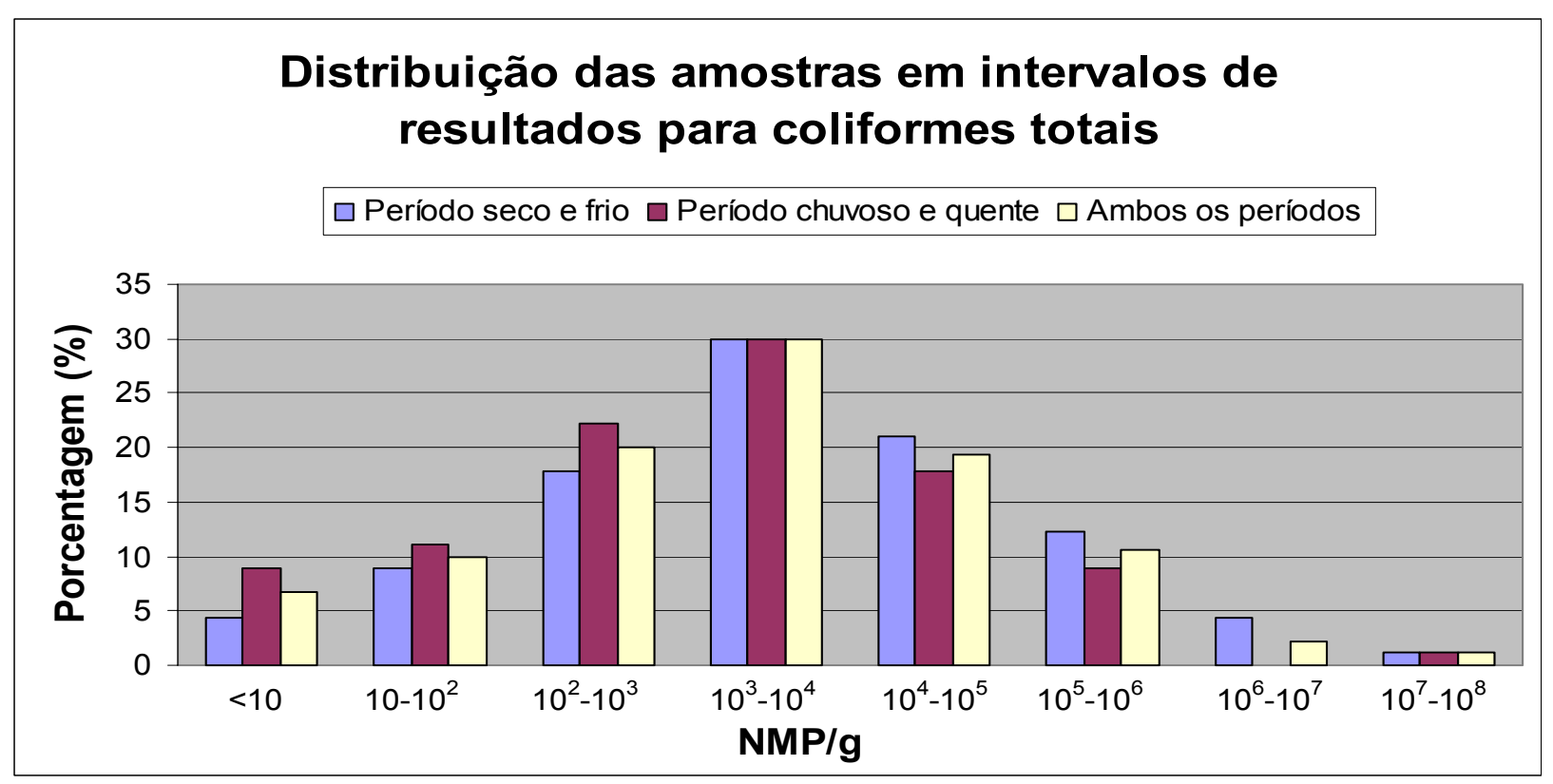


A Tabela 4 distribui os pesqueiros durante os períodos seco e frio; chuvoso e quente e em ambos, de acordo com os resultados de coliformes totais obtidos em $\mathrm{NMP} / \mathrm{g}$ apresentados por intervalos de um ciclo logarítmico, considerando a amostra com mais alto valor do $\mathrm{NMP} / \mathrm{g}$.

A mais alta freqüência de ocorrência de coliformes totais nos pesqueiros está no intervalo de $10^{3}$ a $10^{6} \mathrm{NMP} / \mathrm{g}$, no qual se incluem $21(70,0 \%)$ pesqueiros no período seco e frio; $25(83,3 \%)$ no período chuvoso e quente e $23(76,7 \%)$ em ambos os períodos (Tabela 4).

De acordo com o NMP/g de coliformes totais obtida nas amostras, durante o período seco e frio, encontrou-se $10(33,3 \%)$ pesqueiros com contagens $>10^{5} ; 25$ $(83,3 \%)$ com contagens $>10^{3}$ e $29(96,7 \%)$ com contagens $>10^{1}$; durante o período chuvoso e quente; 7 pesqueiros $(23,3 \%)$ com contagens $>10^{5} ; 24(80,0 \%)$ com contagens $>10^{3}$ e $29(96,7 \%)$ com contagens $>10^{1}$ e durante ambos os períodos encontrou-se 15 pesqueiros $(50,0 \%)$ com contagens $>10^{5} ; 25(83,3 \%)$ com contagens $>10^{4}$ e $30(100,0 \%)$ com contagens $>10^{3}$ (Tabela 4$)$.

Tabela 4 - Distribuição dos pesqueiros nos períodos seco e frio (SE); chuvoso e quente (CH) e em ambos ( $\mathrm{SE}$ e $\mathrm{CH}$ ) de acordo com os resultados de coliformes totais em NMP/g da amostra com mais alto valor, apresentados por intervalos de um ciclo logarítmico - São Paulo - set 2001 - out 2001/fev 2002 - mar 2002

\begin{tabular}{|c|c|c|c|c|c|c|}
\hline \multirow[t]{3}{*}{$\mathrm{NMP} / \mathrm{g}$} & \multicolumn{2}{|c|}{$\begin{array}{c}\text { PERÍODO } \\
\text { SECO E FRIO }\end{array}$} & \multicolumn{2}{|c|}{$\begin{array}{c}\text { PERÍODO } \\
\text { QUENTE E CHUVOSO }\end{array}$} & \multicolumn{2}{|c|}{$\begin{array}{c}\text { PERÍODO } \\
\text { SECO E FRIO E QUENTE E } \\
\text { CHUVOSO }\end{array}$} \\
\hline & N. & $\%$ & N. & $\%$ & N. & $\%$ \\
\hline & PESQUEIROS & PESQUEIROS & PESQUEIROS & PESQUEIROS & PESQUEIROS & PESQUEIROS \\
\hline$<10$ & 1 & $3,3 \%$ & 1 & $3,3 \%$ & 0 & $0,0 \%$ \\
\hline $10-10^{2}$ & 0 & $0,0 \%$ & 2 & $6,7 \%$ & 0 & $0,0 \%$ \\
\hline $10^{2-10^{3}}$ & 4 & $13,3 \%$ & 3 & $10,0 \%$ & 0 & $0,0 \%$ \\
\hline $10^{3-}-10^{4}$ & 8 & $26,7 \%$ & 7 & $23,3 \%$ & 5 & $16,7 \%$ \\
\hline $10^{4-} 10^{5}$ & 7 & $23,3 \%$ & 10 & $33,3 \%$ & 10 & $33,3 \%$ \\
\hline $10^{5-10^{6}}$ & 6 & $20,0 \%$ & 6 & $20,0 \%$ & 10 & $33,3 \%$ \\
\hline $10^{6-}-10^{7}$ & 3 & $10,0 \%$ & 0 & $0,0 \%$ & 3 & $10,0 \%$ \\
\hline $10^{7-}-10^{8}$ & 1 & $3,3 \%$ & 1 & $3,3 \%$ & 2 & $6,7 \%$ \\
\hline TOTAL & 30 & $100,0 \%$ & 30 & $100,0 \%$ & 30 & $100,0 \%$ \\
\hline
\end{tabular}


Figura 3 - Distribuição, em porcentagem, dos 30 pesqueiros nos períodos seco e frio (SE); chuvoso e quente $(\mathrm{CH})$ e em ambos $(\mathrm{SE}$ e $\mathrm{CH}$ ) de acordo com os resultados de maior valor para coliformes totais em NMP/g apresentados por intervalos de um ciclo logarítmico - São Paulo set 2001 - out 2001/fev 2002 - mar 2002

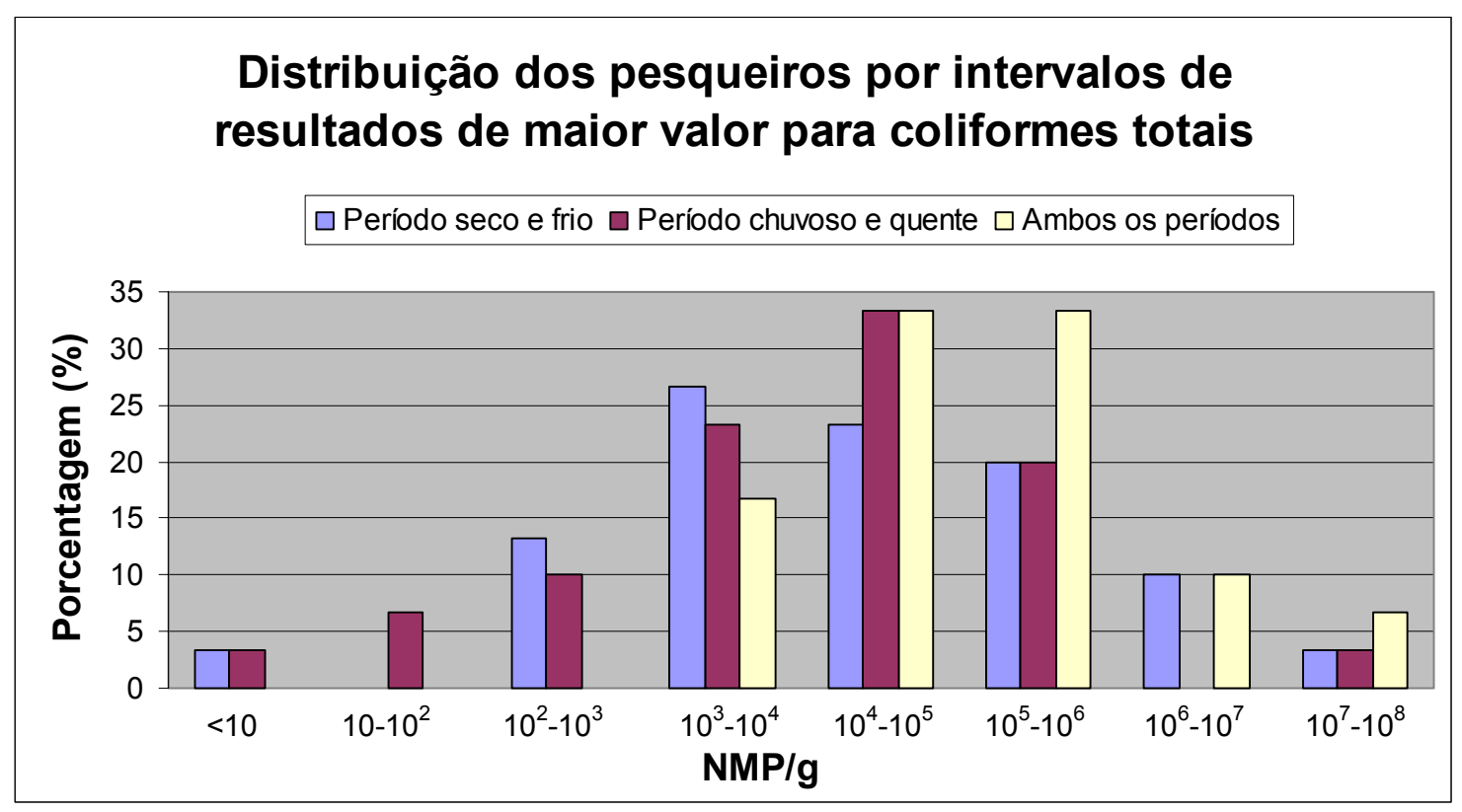

As Tabelas 5 e 6 apresenta os limites máximos e mínimos de NMP/g de coliformes fecais nos períodos seco e frio, chuvoso e quente foram, respectivamente de $<0,1$ a $1,2 \times 10^{4} \mathrm{NMP} / \mathrm{g}$, e $<0,1$ a $6,8 \times 10^{4} \mathrm{NMP} / \mathrm{g}$.

Nas normas sobre alimentos, do âmbito federal não existem padrões para coliformes totais e fecais para o pescado. A Portaria $n^{\circ} 451$ - Código de Vigilância Sanitária do Ministério da Saúde-DNVSA, publicada em 19 de setembro de 1997 apesar de já ter sido revogada e substituída pela Resolução RDC n 12 , de 2 de janeiro de 2001 da Agência Nacional de Vigilância Sanitária (ANVISA), apresenta padrão para coliformes fecais (máximo aceitável de $10^{2} \mathrm{NMP} / \mathrm{g}$ ). O Código Sanitário do Estado de São Paulo - Decreto 12.342, de 27 de setembro de 1978, na sua legislação complementar - Decreto 12.486, de 20 de outubro de 1978 - também determina como padrão máximo para coliformes fecais $10^{2} \mathrm{NMP} / \mathrm{g}$, para produto pescado.

Tomando como padrão a Portaria ${ }^{\circ} 451$ e o Código Sanitário do Estado de São Paulo, assumiu-se a seguinte classificação: amostras que apresentaram resultados com valores iguais ou acima de $10^{2} \mathrm{NMP} / \mathrm{g}$ foram consideradas "amostras positivas" e em desacordo com a legislação; da mesma forma, os pesqueiros que apresentaram pelo 
menos uma amostra em desacordo com esta legislação foram denominados "pesqueiros positivos", sendo apresentados nas tabelas em negrito.

Tabela 5 - Número mais provável por grama de coliformes fecais das amostras analisadas durante o período seco e frio (SE) em pesqueiros da região metropolitana de São Paulo - São Paulo set 2001 - out 2001

\begin{tabular}{|c|c|c|c|}
\hline PESQUEIRO & AMOSTRA 1 & AMOSTRA 2 & AMOSTRA 3 \\
\hline $1 \mathrm{SE}$ & $<4,7 \times 10$ & $<0,5$ & $<5,6 \times 10$ \\
\hline $2 \mathrm{SE}$ & $2,4 \times 10$ & $<2,7 \times 10$ & $3,8 \times 10$ \\
\hline $3 \mathrm{SE}$ & $3,1 \times 10$ & $3,3 \times 10$ & $2,2 \times 10$ \\
\hline 4SE & $<4,0$ & $<4,27$ & 9,45 \\
\hline $5 \mathrm{SE}$ & $<1,6$ & $<3,15$ & 3,15 \\
\hline $6 \mathrm{SE}$ & $<1,6$ & $<1,57$ & $1,2 \times 10$ \\
\hline $7 \mathrm{SE}$ & $<1,6$ & $1,2 \times 10^{2}$ & $1,7 \times 10^{2}$ \\
\hline $8 \mathrm{SE}$ & $<0,2$ & 1,3 & $2,0 \times 10$ \\
\hline 9SE & $1,4 \times 10^{2}$ & $1,4 \times 10^{2}$ & $2,8 \times 10^{3}$ \\
\hline $10 \mathrm{SE}$ & $<0,8$ & $<1,2$ & $<1,3$ \\
\hline $11 \mathrm{SE}$ & $<2,0$ & $<2,5$ & $<2,7$ \\
\hline $12 \mathrm{SE}$ & $<1,5$ & $<2,3$ & $<3,1$ \\
\hline $13 \mathrm{SE}$ & $<0,4$ & $<0,3$ & 0,8 \\
\hline $14 \mathrm{SE}$ & 0,9 & 3,8 & $1,6 \times 10$ \\
\hline $15 \mathrm{SE}$ & 2,3 & $2,0 \times 10^{2}$ & $6,8 \times 10^{2}$ \\
\hline $16 \mathrm{SE}$ & $1,1 \times 10^{2}$ & $1,7 \times 10^{2}$ & $1,5 \times 10^{3}$ \\
\hline $17 \mathrm{SE}$ & $<1,1$ & 1,1 & $2,3 \times 10^{2}$ \\
\hline $18 \mathrm{SE}$ & 0,2 & 4,5 & $3,1 \times 10^{2}$ \\
\hline $19 \mathrm{SE}$ & 2,3 & 4,5 & $3,2 \times 10$ \\
\hline 20SE & $3,6 \times 10$ & $8,1 \times 10$ & $1,3 \times 10^{2}$ \\
\hline $21 \mathrm{SE}$ & $1,6 \times 10$ & $3,2 \times 10$ & $8,6 \times 10^{2}$ \\
\hline $22 \mathrm{SE}$ & 1,8 & $5,9 \times 10$ & $1,2 \times 10^{4}$ \\
\hline $23 \mathrm{SE}$ & $<0,1$ & $<0,17$ & $<0,2$ \\
\hline $24 \mathrm{SE}$ & $1,3 \times 10$ & $1,4 \times 10^{2}$ & $3,2 \times 10^{2}$ \\
\hline $25 \mathrm{SE}$ & 1,5 & 5,6 & 6,7 \\
\hline $26 \mathrm{SE}$ & 1,8 & 2,0 & 2,0 \\
\hline $27 \mathrm{SE}$ & 6,3 & $1,6 \times 10$ & $6,3 \times 10$ \\
\hline $28 \mathrm{SE}$ & $<1,4$ & $<1,7$ & 8,5 \\
\hline 29SE & 3,1 & $1,8 \times 10$ & $2,0 \times 10$ \\
\hline $30 \mathrm{SE}$ & $3,1 \times 10$ & $1,2 \times 10^{2}$ & $1,5 \times 10^{2}$ \\
\hline
\end{tabular}


Tabela 6 - Número mais provável por grama de coliformes fecais das amostras analisadas durante os períodos chuvoso e quente $(\mathrm{CH})$ em pesqueiros da região metropolitana de São Paulo - São Paulo - fev 2002 - mar 2002

\begin{tabular}{|c|c|c|c|}
\hline PESQUEIRO & AMOSTRA 1 & AMOSTRA 2 & AMOSTRA 3 \\
\hline $1 \mathrm{CH}$ & 2,4 & $<0,8$ & 0,9 \\
\hline $2 \mathrm{CH}$ & 2,0 & 2,0 & 8,2 \\
\hline $3 \mathrm{CH}$ & 0,2 & 4,5 & 0,1 \\
\hline $4 \mathrm{CH}$ & $8,5 \times 10$ & 2,5 & $4,3 \times 10^{2}$ \\
\hline $5 \mathrm{CH}$ & $6,8 \times 10^{4}$ & $5,5 \times 10^{4}$ & $5,1 \times 10^{4}$ \\
\hline $6 \mathrm{CH}$ & $5,2 \times 10$ & $3,7 \times 10^{2}$ & $4,9 \times 10$ \\
\hline $7 \mathrm{CH}$ & 0,6 & $<0,4$ & 3,7 \\
\hline $8 \mathrm{CH}$ & $<0,8$ & $<0,2$ & $<0,2$ \\
\hline $9 \mathrm{CH}$ & 4,8 & $2,8 \times 10$ & 1,3 \\
\hline $10 \mathrm{CH}$ & 4,5 & $<0,8$ & 2,0 \\
\hline $11 \mathrm{CH}$ & 0,9 & 0,8 & 1,4 \\
\hline $12 \mathrm{CH}$ & $1,2 \times 10$ & 5,6 & 0,2 \\
\hline $13 \mathrm{CH}$ & 2,2 & 0,7 & $7,9 \times 10^{2}$ \\
\hline $14 \mathrm{CH}$ & 7,3 & $2,9 \times 10^{2}$ & 1,5 \\
\hline $15 \mathrm{CH}$ & 5,6 & 1,4 & 1,1 \\
\hline $16 \mathrm{CH}$ & 3,0 & 0,9 & 1,9 \\
\hline $17 \mathrm{CH}$ & $6,1 \times 10^{3}$ & 4,6 & $1,0 \times 10^{4}$ \\
\hline $18 \mathrm{CH}$ & $<0,8$ & 0,9 & 5,7 \\
\hline $19 \mathrm{CH}$ & 1,5 & $4,1 \times 10^{2}$ & $4,4 \times 10^{3}$ \\
\hline $20 \mathrm{CH}$ & $<0,4$ & 1,8 & $3,3 \times 10^{2}$ \\
\hline $21 \mathrm{CH}$ & $1,1 \times 10$ & 0,8 & 7,9 \\
\hline $22 \mathrm{CH}$ & 0,4 & 2,5 & 3,2 \\
\hline $23 \mathrm{CH}$ & 2,5 & $2,6 \times 10$ & $2,6 \times 10$ \\
\hline $24 \mathrm{CH}$ & $1,5 \times 10^{2}$ & $2,6 \times 10^{4}$ & $1,1 \times 10^{2}$ \\
\hline $25 \mathrm{CH}$ & 0,8 & 9,8 & $2,9 \times 10^{2}$ \\
\hline $26 \mathrm{CH}$ & 2,0 & $9,7 \times 10^{2}$ & 1,2 \\
\hline $27 \mathrm{CH}$ & $<2,2$ & $<1,9$ & $<2,8$ \\
\hline $28 \mathrm{CH}$ & $1,9 \times 10$ & $2,0 \times 10$ & $6,9 \times 10$ \\
\hline $29 \mathrm{CH}$ & 1,8 & 0,2 & 1,8 \\
\hline $30 \mathrm{CH}$ & $<1,3$ & $<1,8$ & $<0,9$ \\
\hline
\end{tabular}


A Tabela 7 apresenta a distribuição das amostras positivas para coliformes fecais, durante os períodos seco e frio; chuvoso e quente e em ambos os períodos, nos pesqueiros da região metropolitana de São Paulo. De acordo com o número de amostras positivas para coliformes fecais, observou-se no período seco e frio um total de, 19 $(21,1 \%)$; no período chuvoso e quente um total de 17 (18,9\%) e em ambos os períodos $36(20,0 \%)$ amostras positivas (Tabela 7$)$. 
Tabela 7 - Número de amostras classificadas como positivas para coliformes fecais nos períodos seco e frio (SE); chuvoso e quente $(\mathrm{CH})$ e em ambos, em pesqueiros da região metropolitana de São Paulo - São Paulo - set 2001 - out 2001/fev 2002 - mar 2002

\begin{tabular}{|c|c|c|c|}
\hline PESQUEIRO & $\begin{array}{c}\text { SE/ } \\
\text { N. AMOSTRAS } \\
\text { POSITIVAS(*) }\end{array}$ & $\begin{array}{c}\mathrm{CH} / \\
\text { N. AMOSTRAS } \\
\text { POSITIVAS }\end{array}$ & $\begin{array}{c}\text { SE e CH/ } \\
\text { N. AMOSTRAS } \\
\text { POSITIVAS }\end{array}$ \\
\hline 1 & 0 & 0 & 0 \\
\hline 2 & 0 & 0 & 0 \\
\hline 3 & 0 & 0 & 0 \\
\hline 4 & 0 & 1 & 1 \\
\hline 5 & 0 & 3 & 3 \\
\hline 6 & 0 & 1 & 1 \\
\hline 7 & 2 & 0 & 2 \\
\hline 8 & 0 & 0 & 0 \\
\hline 9 & 3 & 0 & 3 \\
\hline 10 & 0 & 0 & 0 \\
\hline 11 & 0 & 0 & 0 \\
\hline 12 & 0 & 0 & 0 \\
\hline 13 & 0 & 1 & 1 \\
\hline 14 & 0 & 1 & 1 \\
\hline 15 & 2 & 0 & 2 \\
\hline 16 & 3 & 0 & 3 \\
\hline 17 & 1 & 2 & 3 \\
\hline 18 & 1 & 0 & 1 \\
\hline 19 & 0 & 2 & 2 \\
\hline 20 & 1 & 1 & 2 \\
\hline 21 & 1 & 0 & 1 \\
\hline 22 & 1 & 0 & 1 \\
\hline 23 & 0 & 0 & 0 \\
\hline 24 & 2 & 3 & 5 \\
\hline 25 & 0 & 1 & 1 \\
\hline 26 & 0 & 1 & 1 \\
\hline 27 & 0 & 0 & 0 \\
\hline 28 & 0 & 0 & 0 \\
\hline 29 & 0 & 0 & 0 \\
\hline 30 & 2 & 0 & 2 \\
\hline TOTAL & 19 & 17 & 36 \\
\hline
\end{tabular}

(*) Amostra Positiva: quando o resultado da enumeração de coliformes fecais foi igual ou superior a $10^{2}$ $\mathrm{NMP} / \mathrm{g}$ de peixe. 
Figura 4 - Porcentagem de amostras positivas para coliformes fecais de um total de 180 amostras colhidas em 30 pesqueiros da região metropolitana de São Paulo, independentemente do período estudado - São Paulo - set 2001 - out $2001 /$ fev 2002 - mar 2002

\section{Amostras positivas para coliformes fecais}

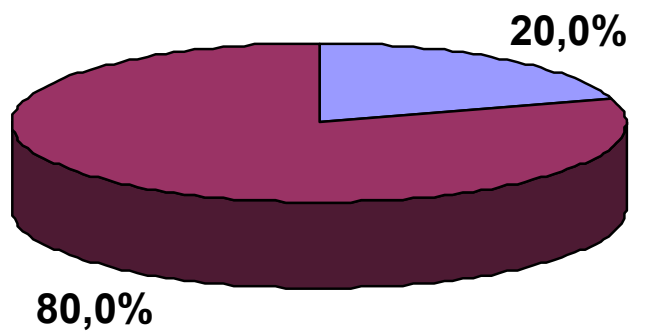

A Tabela 8 apresenta a distribuição dos pesqueiros, durante os períodos seco e frio; chuvoso e quente e em ambos acordo com o número de amostras positivas para coliformes fecais, indicando o nível de contaminação em relação ao Código de Vigilância Sanitária do Ministério da Saúde- DNVSA- Portaria n 451, de 19/09/97, dos pesqueiros da região metropolitana de São Paulo e obteve-se, durante o período seco e frio cinco $(16,7 \%)$ pesqueiros com uma amostra positiva; quatro $(13,3 \%)$ com duas amostras positivas; dois $(6,7 \%)$ com três amostras positivas e 19 (63,3\%) não apresentaram amostras positivas (Tabela 8).

Considerando a distribuição dos pesqueiros de acordo com o número de amostras positivas para coliformes fecais, indicando nível de contaminação durante o período quente e chuvoso, sete $(23,3 \%)$ apresentaram uma amostra positiva; dois $(6,7 \%)$ apresentaram duas amostras positivas; dois $(6,7 \%)$ apresentaram três amostras positivas e $19(63,3 \%)$ não apresentaram amostras positivas (Tabela 8).

$\mathrm{Na}$ tabela 8 observa-se que nove $(30,0 \%)$ pesqueiros apresentaram uma amostra positiva, considerando-se ambos os períodos, enquanto que 11 (36,7\%) não apresentaram nenhum resultado positivo. Cinco (16,7\%) pesqueiros apresentaram duas amostras positivas; quatro (13,3\%) apresentaram três amostras positivas e um $(3,3 \%)$ apresentou cinco amostras positivas. 
Tabela 8 - Distribuição dos pesqueiros estudados, da região metropolitana de São Paulo, durante os períodos seco e frio (SE); chuvoso e quente $(\mathrm{CH})$ e em ambos $(\mathrm{SE}$ e $\mathrm{CH}$ ) de acordo com o número de amostras positivas para coliformes fecais - São Paulo - set 2001 - out 2001/fev 2002 - mar 2002

\begin{tabular}{lccc}
\hline $\begin{array}{l}\text { NÚMERO DE PESQUEIROS } \\
\text { COM: }\end{array}$ & $\begin{array}{c}\text { PERÍODO } \\
\text { SECO E FRIO }\end{array}$ & $\begin{array}{c}\text { PERÍODO } \\
\text { QUENTE E } \\
\text { CHUVOSO }\end{array}$ & $\begin{array}{c}\text { PERÍODO } \\
\text { SECO E FRIO E QUENTE } \\
\text { E CHUVOSO }\end{array}$ \\
\hline UMA amostra positiva & 5 & 7 & 9 \\
DUAS amostras positivas & 4 & 2 & 5 \\
TRÊS amostras positivas & 2 & 2 & 4 \\
QUATRO amostras positivas & 0 & 0 & 0 \\
CINCO amostras positivas & 0 & 0 & 1 \\
SEIS amostras positivas & 0 & 0 & 0 \\
NEHUMA amostra positiva & 19 & 19 & 30 \\
\hline TOTAL & 30 & 30 &
\end{tabular}

A Tabela 9 apresenta a distribuição dos pesqueiros durante os períodos seco e frio; chuvoso e quente, e em ambos, de acordo com o número de amostras positivas para coliformes fecais, indicando grau de inadequação, em relação a legislação, dos pesqueiros da região metropolitana de São Paulo. Os pesqueiros com pelo menos uma, duas, três ou mais amostras positivas, foram concentrados, distribuídos e considerados positivos, para indicar o grau de inadequação destes estabelecimentos em relação a esta legislação.

Considerando a distribuição dos pesqueiros de acordo com o número de amostras positivas para coliformes fecais, indicando o grau de inadequação durante o período seco e frio mostrou que $11(36,7 \%)$ apresentaram pelo menos uma amostra positiva; seis $(20,0 \%)$ apresentaram pelo menos duas amostras positivas; dois $(6,7 \%)$ apresentaram pelo menos três amostras positivas (Tabela 9).

Considerando a distribuição dos pesqueiros de acordo com o número de amostras positivas para coliformes fecais indicando o grau de inadequação durante o período quente e chuvoso mostrou que 11 (36,7\%) apresentaram pelo menos uma amostra positiva; quatro $(13,3 \%)$ apresentaram pelo menos duas amostras positivas; dois $(6,7 \%)$ apresentaram pelo menos três amostras positivas (Tabela 9). 
Pela Tabela 9 constata-se ainda que $19(63,3 \%)$ pesqueiros apresentaram pelo menos uma amostra positiva durante o estudo e que dez $(33,3 \%)$ apresentaram pelo menos duas amostras positivas.

Tabela 9 - Distribuição dos pesqueiros estudados, da região metropolitana de São Paulo, durante os períodos seco e frio (SE); chuvoso e quente $(\mathrm{CH})$ e em ambos $(\mathrm{SE}$ e $\mathrm{CH})$ de acordo com uma ocorrência crescente de amostras positivas para coliformes fecais - São Paulo - set 2001 out 2001/fev 2002 - mar 2002

\begin{tabular}{lccc}
\hline $\begin{array}{l}\text { NÚMERO DE PESQUEIROS } \\
\text { COM PELO MENOS: }\end{array}$ & $\begin{array}{c}\text { PERÍODO } \\
\text { SECO E FRIO }\end{array}$ & $\begin{array}{c}\text { PERÍODO } \\
\text { QUENTE E } \\
\text { CHUVOSO }\end{array}$ & $\begin{array}{c}\text { PERÍODO } \\
\text { SECO E FRIO E } \\
\text { QUENTE E CHUVOSO }\end{array}$ \\
\hline UMA amostra positiva & 11 & 11 & 19 \\
DUAS amostras positivas & 6 & 4 & 10 \\
TRÊS amostras positivas & 2 & 2 & 5 \\
QUATRO amostras positivas & 0 & 0 & 1 \\
CINCO amostras positivas & 0 & 0 & 1 \\
SEIS amostras positivas & 0 & 0 & 0 \\
\hline
\end{tabular}

Na Tabela 10 observa-se que em relação a presença de Salmonella spp, durante o período seco e frio, cinco $(5,6 \%)$ amostras foram positivas em dois $(6,7 \%)$ pesqueiros, e na Tabela 11, que durante o período chuvoso e quente, nove $(10,0 \%)$ amostras foram positivas em cinco $(16,7 \%)$ pesqueiros. 
Tabela 10 - Pesquisa de Salmonella spp nas três amostras de peixe analisadas durante o período seco e frio (SE) em pesqueiros da região metropolitana de São Paulo - São Paulo - set 2001 - out 2001

\begin{tabular}{|c|c|c|c|}
\hline PESQUEIRO & AMOSTRA 1 & AMOSTRA 2 & AMOSTRA 3 \\
\hline $1 \mathrm{SE}$ & $\mathrm{N}(*)$ & $\mathrm{N}$ & $\mathrm{N}$ \\
\hline $2 \mathrm{SE}$ & $\mathrm{N}$ & $\mathrm{N}$ & $\mathrm{N}$ \\
\hline $3 \mathrm{SE}$ & $\mathrm{N}$ & $\mathrm{N}$ & $\mathrm{N}$ \\
\hline 4SE & $\mathrm{N}$ & $\mathrm{N}$ & $\mathrm{N}$ \\
\hline 5SE & $\mathrm{N}$ & $\mathrm{N}$ & $\mathrm{N}$ \\
\hline $6 \mathrm{SE}$ & $\mathrm{N}$ & $\mathrm{N}$ & $\mathrm{N}$ \\
\hline 7SE & $\mathrm{N}$ & $\mathrm{N}$ & $\mathrm{N}$ \\
\hline $8 \mathrm{SE}$ & $\mathrm{N}$ & $\mathrm{N}$ & $\mathrm{N}$ \\
\hline 9SE & Positiva & Positiva & Positiva \\
\hline 10SE & $\mathrm{N}$ & $\mathrm{N}$ & $\mathrm{N}$ \\
\hline $11 \mathrm{SE}$ & $\mathrm{N}$ & $\mathrm{N}$ & $\mathrm{N}$ \\
\hline $12 \mathrm{SE}$ & $\mathrm{N}$ & $\mathrm{N}$ & $\mathrm{N}$ \\
\hline $13 \mathrm{SE}$ & $\mathrm{N}$ & $\mathrm{N}$ & $\mathrm{N}$ \\
\hline 14SE & $\mathrm{N}$ & $\mathrm{N}$ & $\mathrm{N}$ \\
\hline $15 \mathrm{SE}$ & $\mathrm{N}$ & $\mathrm{N}$ & $\mathrm{N}$ \\
\hline 16SE & $\mathrm{N}$ & $\mathrm{N}$ & $\mathrm{N}$ \\
\hline $17 \mathrm{SE}$ & $\mathrm{N}$ & $\mathrm{N}$ & $\mathrm{N}$ \\
\hline 18SE & $\mathrm{N}$ & $\mathrm{N}$ & $\mathrm{N}$ \\
\hline 19SE & $\mathrm{N}$ & Positiva & Positiva \\
\hline 20SE & $\mathrm{N}$ & $\mathrm{N}$ & $\mathrm{N}$ \\
\hline 21SE & $\mathrm{N}$ & $\mathrm{N}$ & $\mathrm{N}$ \\
\hline 22SE & $\mathrm{N}$ & $\mathrm{N}$ & $\mathrm{N}$ \\
\hline 23SE & $\mathrm{N}$ & $\mathrm{N}$ & $\mathrm{N}$ \\
\hline 24SE & $\mathrm{N}$ & $\mathrm{N}$ & $\mathrm{N}$ \\
\hline $25 \mathrm{SE}$ & $\mathrm{N}$ & $\mathrm{N}$ & $\mathrm{N}$ \\
\hline 26SE & $\mathrm{N}$ & $\mathrm{N}$ & $\mathrm{N}$ \\
\hline $27 \mathrm{SE}$ & $\mathrm{N}$ & $\mathrm{N}$ & $\mathrm{N}$ \\
\hline 28SE & $\mathrm{N}$ & $\mathrm{N}$ & $\mathrm{N}$ \\
\hline 29SE & $\mathrm{N}$ & $\mathrm{N}$ & $\mathrm{N}$ \\
\hline $30 \mathrm{SE}$ & $\mathrm{N}$ & $\mathrm{N}$ & $\mathrm{N}$ \\
\hline
\end{tabular}

(*) N: amostra negativa. 
Tabela 11 - Pesquisa de Salmonella spp nas três amostras de peixe analisadas durante o período chuvoso e quente $(\mathrm{CH})$ em pesqueiros da região metropolitana de São Paulo - São Paulo - fev 2002 mar 2002

\begin{tabular}{|c|c|c|c|}
\hline PESQUEIRO & AMOSTRA 1 & AMOSTRA 2 & AMOSTRA 3 \\
\hline $1 \mathrm{CH}$ & $\mathrm{N}(*)$ & Positiva & Positiva \\
\hline $2 \mathrm{CH}$ & $\mathrm{N}$ & $\mathrm{N}$ & $\mathrm{N}$ \\
\hline $3 \mathrm{CH}$ & $\mathrm{N}$ & $\mathrm{N}$ & $\mathrm{N}$ \\
\hline $4 \mathrm{CH}$ & $\mathrm{N}$ & $\mathrm{N}$ & $\mathrm{N}$ \\
\hline $5 \mathrm{CH}$ & $\mathrm{N}$ & $\mathrm{N}$ & $\mathrm{N}$ \\
\hline $6 \mathrm{CH}$ & $\mathrm{N}$ & $\mathrm{N}$ & $\mathrm{N}$ \\
\hline $7 \mathrm{CH}$ & $\mathrm{N}$ & $\mathrm{N}$ & $\mathrm{N}$ \\
\hline $8 \mathrm{CH}$ & $\mathrm{N}$ & $\mathrm{N}$ & $\mathrm{N}$ \\
\hline $9 \mathrm{CH}$ & Positiva & Positiva & Positiva \\
\hline $10 \mathrm{CH}$ & $\mathrm{N}$ & $\mathrm{N}$ & Positiva \\
\hline $11 \mathrm{CH}$ & $\mathrm{N}$ & $\mathrm{N}$ & $\mathrm{N}$ \\
\hline $12 \mathrm{CH}$ & $\mathrm{N}$ & $\mathrm{N}$ & $\mathrm{N}$ \\
\hline $13 \mathrm{CH}$ & $\mathrm{N}$ & Positiva & $\mathrm{N}$ \\
\hline $14 \mathrm{CH}$ & $\mathrm{N}$ & $\mathrm{N}$ & $\mathrm{N}$ \\
\hline $15 \mathrm{CH}$ & $\mathrm{N}$ & Positiva & Positiva \\
\hline $16 \mathrm{CH}$ & $\mathrm{N}$ & $\mathrm{N}$ & $\mathrm{N}$ \\
\hline $17 \mathrm{CH}$ & $\mathrm{N}$ & $\mathrm{N}$ & $\mathrm{N}$ \\
\hline $18 \mathrm{CH}$ & $\mathrm{N}$ & $\mathrm{N}$ & $\mathrm{N}$ \\
\hline $19 \mathrm{CH}$ & $\mathrm{N}$ & $\mathrm{N}$ & $\mathrm{N}$ \\
\hline $20 \mathrm{CH}$ & $\mathrm{N}$ & $\mathrm{N}$ & $\mathrm{N}$ \\
\hline $21 \mathrm{CH}$ & $\mathrm{N}$ & $\mathrm{N}$ & $\mathrm{N}$ \\
\hline $22 \mathrm{CH}$ & $\mathrm{N}$ & $\mathrm{N}$ & $\mathrm{N}$ \\
\hline $23 \mathrm{CH}$ & $\mathrm{N}$ & $\mathrm{N}$ & $\mathrm{N}$ \\
\hline $24 \mathrm{CH}$ & $\mathrm{N}$ & $\mathrm{N}$ & $\mathrm{N}$ \\
\hline $25 \mathrm{CH}$ & $\mathrm{N}$ & $\mathrm{N}$ & $\mathrm{N}$ \\
\hline $26 \mathrm{CH}$ & $\mathrm{N}$ & $\mathrm{N}$ & $\mathrm{N}$ \\
\hline $27 \mathrm{CH}$ & $\mathrm{N}$ & $\mathrm{N}$ & $\mathrm{N}$ \\
\hline $28 \mathrm{CH}$ & $\mathrm{N}$ & $\mathrm{N}$ & $\mathrm{N}$ \\
\hline $29 \mathrm{CH}$ & $\mathrm{N}$ & $\mathrm{N}$ & $\mathrm{N}$ \\
\hline $30 \mathrm{CH}$ & $\mathrm{N}$ & $\mathrm{N}$ & $\mathrm{N}$ \\
\hline
\end{tabular}

(*) N: amostra negativa. 
A Tabela 12 apresenta o total de $14(46,7 \%)$ amostras positivas para Salmonella spp a partir de seis $(20,0 \%)$ pesqueiros diferentes, considerados os dois períodos de estudo (SE e $\mathrm{CH})$.

Tabela 12 - Distribuição do número de amostras positivas para Salmonella spp, nos períodos seco e frio (SE); chuvoso e quente $(\mathrm{CH})$ e em ambos $(\mathrm{SE}$ e $\mathrm{CH}$ ), em pesqueiros da região metropolitana de São Paulo- São Paulo - set 2001 - out 2001/fev 2002 - mar 2002

\begin{tabular}{|c|c|c|c|}
\hline PESQUEIRO & $\begin{array}{l}\text { SE/ N. AMOSTRAS } \\
\text { POSITIVAS }\end{array}$ & $\begin{array}{l}\mathrm{CH} / \mathrm{N} . \text { AMOSTRAS } \\
\text { POSITIVAS }\end{array}$ & $\begin{array}{c}\mathrm{SE}+\mathrm{CH} / \mathrm{N} \\
\text { AMOSTRAS } \\
\text { POSITIVAS }\end{array}$ \\
\hline 1 & 0 & 2 & 2 \\
\hline 2 & 0 & 0 & 0 \\
\hline 3 & 0 & 0 & 0 \\
\hline 4 & 0 & 0 & 0 \\
\hline 5 & 0 & 0 & 0 \\
\hline 6 & 0 & 0 & 0 \\
\hline 7 & 0 & 0 & 0 \\
\hline 8 & 0 & 0 & 0 \\
\hline 9 & 3 & 3 & 6 \\
\hline 10 & 0 & 1 & 1 \\
\hline 11 & 0 & 0 & 0 \\
\hline 12 & 0 & 0 & 0 \\
\hline 13 & 0 & 1 & 1 \\
\hline 14 & 0 & 0 & 0 \\
\hline 15 & 0 & 2 & 2 \\
\hline 16 & 0 & 0 & 0 \\
\hline 17 & 0 & 0 & 0 \\
\hline 18 & 0 & 0 & 0 \\
\hline 19 & 2 & 0 & 2 \\
\hline 20 & 0 & 0 & 0 \\
\hline 21 & 0 & 0 & 0 \\
\hline 22 & 0 & 0 & 0 \\
\hline 23 & 0 & 0 & 0 \\
\hline 24 & 0 & 0 & 0 \\
\hline 25 & 0 & 0 & 0 \\
\hline 26 & 0 & 0 & 0 \\
\hline 27 & 0 & 0 & 0 \\
\hline 28 & 0 & 0 & 0 \\
\hline 29 & 0 & 0 & 0 \\
\hline 30 & 0 & 0 & 0 \\
\hline TOTAL & 5 & 9 & 14 \\
\hline
\end{tabular}


Figura 5 - Porcentagem de amostras positivas para Salmonella spp de um total de 180 amostras colhidas em 30 pesqueiros da região metropolitana de São Paulo, independentemente do período estudado - São Paulo - set 2001 - out 2001/fev 2002 - mar 2002

\section{Amostras positivas para Salmonella spp}

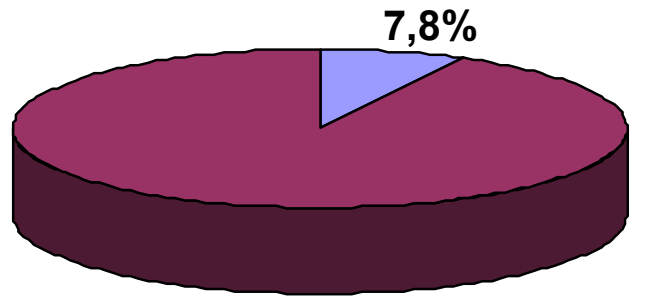

$\square$ positivas

$\square$ negativas

$92,2 \%$ 
A Tabela 13 apresenta a distribuição durante os períodos seco e frio, chuvoso e quente e em ambos, de amostras positivas para Salmonella spp, de acordo com a freqüência de ocorrência de amostras positivas, indicando nível de contaminação dos pesqueiros, em relação ao Código de Vigilância Sanitária - Ministério da SaúdeDNVSA- Portaria $n^{\circ} 451$, de 19/09/97, dos pesqueiros da região metropolitana de São Paulo.

Considerando a distribuição dos pesqueiros de acordo com o número de amostras positivas para Salmonella spp, indicando nível de contaminação observou-se que, durante o período seco e frio, um $(3,3 \%)$ apresentou duas amostras positivas; um $(3,3 \%)$ apresentou três amostras positivas e 28 (93,3\%) não apresentaram amostras positivas, durante o período quente e chuvoso, dois $(6,7 \%)$ apresentaram uma amostra positiva; dois $(6,7 \%)$ apresentaram duas amostras positivas; um $(3,3 \%)$ apresentou três amostras positivas e $25(83,3 \%)$ não apresentaram amostras positivas e considerando ambos os períodos, dois $(6,7 \%)$ apresentaram uma amostra positiva; três $(10,0 \%)$ apresentaram duas amostras positivas; um (3,3\%) apresentou seis amostras positivas e $24(80,0 \%)$ não apresentaram amostras positivas (Tabela 13). 
Tabela 13 - Distribuição dos pesqueiros estudados, da região metropolitana de São Paulo durante os períodos seco e frio (SE); chuvoso e quente $(\mathrm{CH})$ e em ambos $(\mathrm{SE}$ e $\mathrm{CH})$, de acordo com o número de amostras positivas para Salmonella spp - São Paulo - set 2001 - out 2001/fev 2002 - mar 2002

\begin{tabular}{lccc}
\hline NÚMERO DE PESQUEIROS & $\begin{array}{c}\text { PERÍODO } \\
\text { COM: }\end{array}$ & $\begin{array}{c}\text { PERÍODO } \\
\text { QUENTE E } \\
\text { CHUVOSO }\end{array}$ & $\begin{array}{c}\text { PERÍODO } \\
\text { SECO E FRIO E QUENTE } \\
\text { E CHUVOSO }\end{array}$ \\
\hline UMA amostra positiva & 0 & 2 & 2 \\
DUAS amostras positivas & 1 & 2 & 3 \\
TRÊS amostras positivas & 1 & 1 & 0 \\
QUATRO amostras positivas & 0 & 0 & 0 \\
CINCO amostras positivas & 0 & 0 & 0 \\
SEIS amostras positivas & 0 & 0 & 1 \\
NENHUMA amostra positiva & 28 & 25 & 30 \\
\hline TOTAL & 30 & 30 & 24 \\
\hline
\end{tabular}

De acordo com a Tabela 14, durante o período seco e frio dois $(6,7 \%)$ pesqueiros apresentaram pelo menos uma amostra positiva, também dois $(6,7 \%)$ apresentaram pelo menos duas amostras positivas enquanto que somente um $(3,3 \%)$ apresentou pelo menos três amostras positivas; já no período chuvoso e quente, obteve-se cinco $(16,7 \%)$ pesqueiros com pelo menos uma amostra positiva para Salmonella spp; três $(10,0 \%)$ com pelo menos duas amostras positivas e um $(3,3 \%)$ com pelo menos três amostras positivas.

Considerando a distribuição dos pesqueiros, concentrando os resultados, de acordo com o número mínimo de amostras positivas para Salmonella spp, indicando o grau de inadequação em relação a legislação durante o ambos os períodos mostrou que seis $(20,0 \%)$ apresentaram pelo menos uma amostra positiva; quatro $(13,3 \%)$ apresentaram pelo menos duas amostras positivas; um (3,3\%) apresentou pelo menos seis amostras positivas (Tabela 14). 
Tabela 14 - Distribuição dos pesqueiros estudados, da região metropolitana de São Paulo, durante os períodos seco e frio (SE); chuvoso e quente $(\mathrm{CH})$ e em ambos (SE e $\mathrm{CH}$ ), de acordo com o número de amostras positivas para Salmonella spp - São Paulo - set 2001 - out 2001/fev 2002 - mar 2002

\begin{tabular}{lccc}
\hline $\begin{array}{l}\text { NÚMERO DE PESQUEIROS } \\
\text { COM PELO MENOS: }\end{array}$ & $\begin{array}{c}\text { PERÍODO } \\
\text { SECO E FRIO }\end{array}$ & $\begin{array}{c}\text { PERÍODO } \\
\text { QUENTE E } \\
\text { CHUVOSO }\end{array}$ & $\begin{array}{c}\text { PERÍODO } \\
\text { SECO E FRIO E QUENTE } \\
\text { E CHUVOSO }\end{array}$ \\
\hline UMA amostra positiva & 2 & 5 & 6 \\
DUAS amostras positivas & 2 & 3 & 4 \\
TRÊS amostras positivas & 1 & 1 & 1 \\
QUATRO amostras positivas & 0 & 0 & 1 \\
CINCO amostras positivas & 0 & 0 & 1 \\
SEIS amostras positivas & 0 & 0 & 1 \\
\hline
\end{tabular}

A Tabela 15 apresenta a presença de coliformes fecais ou Salmonella spp nas amostras colhidas durante os períodos seco e frio; chuvoso e quente, em relação a presença de pelo menos uma amostra positiva, nos pesqueiros da região metropolitana de São Paulo. Os pesqueiros que apresentaram pelo menos uma amostra em desacordo com a legislação foram considerados como propriedades positivas.

Considerando a distribuição dos pesqueiros com pelo menos uma amostra positiva para coliformes fecais ou Salmonella spp, observou-se no período seco e frio, para coliformes fecais um total de $11(36,7 \%)$ pesqueiros positivos e para Salmonella spp um total de dois $(6,7 \%)$ pesqueiros positivos (Tabela 15).

Considerando a distribuição dos pesqueiros com pelo menos uma amostra positiva para coliformes fecais ou Salmonella spp, observou-se no período chuvoso e quente, para coliformes fecais um total de $11(36,7 \%)$ pesqueiros positivos e para Salmonella spp. um total de cinco (16,7\%) pesqueiros positivos (Tabela 15).

Considerando a distribuição dos pesqueiros com pelo menos uma amostra positiva para coliformes fecais ou Salmonella spp, em ambos os períodos, observou-se um total de $21(70,0 \%)$ pesqueiros positivos (Tabela 15$)$. 
Tabela 15 - Presença de coliformes fecais ou Salmonella spp nas amostras colhidas durante os períodos seco e frio (SE); chuvoso e quente $(\mathrm{CH})$, em relação a presença de pelo menos uma amostra positiva, nos pesqueiros da região metropolitana de São Paulo - São Paulo - fev 2002 - mar 2002

\begin{tabular}{|c|c|c|c|c|c|}
\hline PESQUEIRO & $\begin{array}{c}\mathrm{SE} / \\
\text { COLIFORMES } \\
\text { FECAIS }\end{array}$ & $\begin{array}{c}\mathrm{SE} / \\
\text { Salmonella spp }\end{array}$ & $\begin{array}{c}\mathrm{CH} / \\
\text { COLIFORMES } \\
\text { FECAIS }\end{array}$ & $\begin{array}{c}\mathrm{CH} / \\
\text { Salmonella } \mathrm{spp}\end{array}$ & $\begin{array}{c}\mathrm{SE}+\mathrm{CH} / \\
\text { COLIFORMES } \\
\text { FECAIS OU } \\
\text { Salmonella spp }\end{array}$ \\
\hline 1 & $\mathrm{~N}(*)$ & $\mathrm{N}$ & $\mathrm{N}$ & Positiva & Positiva \\
\hline 2 & $\mathrm{~N}$ & $\mathrm{~N}$ & $\mathrm{~N}$ & $\mathrm{~N}$ & $\mathrm{~N}$ \\
\hline 3 & $\mathrm{~N}$ & $\mathrm{~N}$ & $\mathrm{~N}$ & $\mathrm{~N}$ & $\mathrm{~N}$ \\
\hline 4 & $\mathrm{~N}$ & $\mathrm{~N}$ & Positiva & $\mathrm{N}$ & Positiva \\
\hline 5 & $\mathrm{~N}$ & $\mathrm{~N}$ & Positiva & $\mathrm{N}$ & Positiva \\
\hline 6 & $\mathrm{~N}$ & $\mathrm{~N}$ & Positiva & $\mathrm{N}$ & Positiva \\
\hline 7 & Positiva & $\mathrm{N}$ & $\mathrm{N}$ & $\mathrm{N}$ & Positiva \\
\hline 8 & $\mathrm{~N}$ & $\mathrm{~N}$ & $\mathrm{~N}$ & $\mathrm{~N}$ & $\mathrm{~N}$ \\
\hline 9 & Positiva & Positiva & $\mathrm{N}$ & Positiva & Positiva \\
\hline 10 & $\mathrm{~N}$ & $\mathrm{~N}$ & $\mathrm{~N}$ & Positiva & Positiva \\
\hline 11 & $\mathrm{~N}$ & $\mathrm{~N}$ & $\mathrm{~N}$ & $\mathrm{~N}$ & $\mathrm{~N}$ \\
\hline 12 & $\mathrm{~N}$ & $\mathrm{~N}$ & $\mathrm{~N}$ & $\mathrm{~N}$ & $\mathrm{~N}$ \\
\hline 13 & $\mathrm{~N}$ & $\mathrm{~N}$ & Positiva & Positiva & Positiva \\
\hline 14 & $\mathrm{~N}$ & $\mathrm{~N}$ & Positiva & $\mathrm{N}$ & Positiva \\
\hline 15 & Positiva & $\mathrm{N}$ & $\mathrm{N}$ & Positiva & Positiva \\
\hline 16 & Positiva & $\mathrm{N}$ & $\mathrm{N}$ & $\mathrm{N}$ & Positiva \\
\hline 17 & Positiva & $\mathrm{N}$ & Positiva & $\mathrm{N}$ & Positiva \\
\hline 18 & Positiva & $\mathrm{N}$ & $\mathrm{N}$ & $\mathrm{N}$ & Positiva \\
\hline 19 & $\mathrm{~N}$ & Positiva & Positiva & $\mathrm{N}$ & Positiva \\
\hline 20 & Positiva & $\mathrm{N}$ & Positiva & $\mathrm{N}$ & Positiva \\
\hline 21 & Positiva & $\mathrm{N}$ & $\mathrm{N}$ & $\mathrm{N}$ & Positiva \\
\hline 22 & Positiva & $\mathrm{N}$ & $\mathrm{N}$ & $\mathrm{N}$ & Positiva \\
\hline 23 & $\mathrm{~N}$ & $\mathrm{~N}$ & $\mathrm{~N}$ & $\mathrm{~N}$ & $\mathrm{~N}$ \\
\hline 24 & Positiva & $\mathrm{N}$ & Positiva & $\mathrm{N}$ & Positiva \\
\hline 25 & $\mathrm{~N}$ & $\mathrm{~N}$ & Positiva & $\mathrm{N}$ & Positiva \\
\hline 26 & $\mathrm{~N}$ & $\mathrm{~N}$ & Positiva & $\mathrm{N}$ & Positiva \\
\hline 27 & $\mathrm{~N}$ & $\mathrm{~N}$ & $\mathrm{~N}$ & $\mathrm{~N}$ & $\mathrm{~N}$ \\
\hline 28 & $\mathrm{~N}$ & $\mathrm{~N}$ & $\mathrm{~N}$ & $\mathrm{~N}$ & $\mathrm{~N}$ \\
\hline 29 & $\mathrm{~N}$ & $\mathrm{~N}$ & $\mathrm{~N}$ & $\mathrm{~N}$ & $\mathrm{~N}$ \\
\hline 30 & Positiva & $\mathrm{N}$ & $\mathrm{N}$ & $\mathrm{N}$ & Positiva \\
\hline
\end{tabular}

(*) N: amostra negativa 
Figura 6 - Porcentagem de pesqueiros positivos para coliformes fecais, do total de 30 pesqueiros da região metropolitana de São Paulo estudados, independentemente do período analisado - São Paulo - set 2001 - out 2001/fev 2002 - mar 2002

\section{Pesqueiros positivos para coliformes fecais}

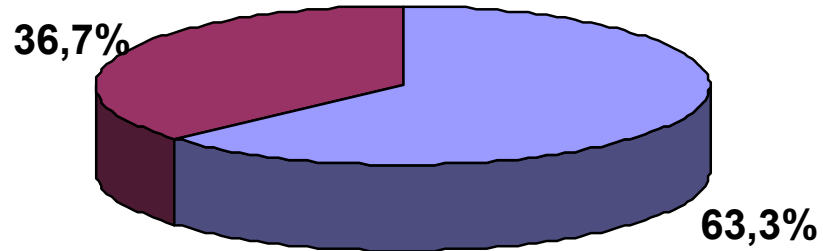

$\square$ positivos

$\square$ negativos

$63,3 \%$

Figura 7 - Porcentagem de pesqueiros positivos para Salmonella spp, do total de 30 pesqueiros da região metropolitana de São Paulo estudados, independentemente do período analisado - São Paulo - set 2001 - out 2001/fev 2002 - mar 2002

\section{Pesqueiros positivos para Salmonella spp}

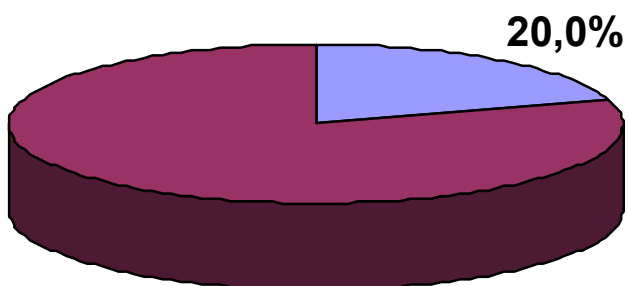

$\square$ positivos

$80,0 \%$ 
A Tabela 16 apresenta a distribuição durante os períodos seco e frio; chuvoso e quente, e em ambos, de acordo com os resultados positivos encontrados de coliformes fecais ou Salmonella spp encontrados em pelo menos uma das amostras colhidas dos pesqueiros da região metropolitana de São Paulo.

Tabela 16 - Distribuição durante os períodos seco e frio (SE); chuvoso e quente $(\mathrm{CH})$, de acordo com os resultados positivos encontrados de coliformes fecais ou Salmonella spp encontrados em pelo menos uma das amostras colhidas dos pesqueiros da região metropolitana de São Paulo - São Paulo - fev 2002 - mar 2002

\begin{tabular}{lccc}
\hline N. DE PESQUEIROS COM & PERÍODO & PERÍODO & PERÍODO \\
AMOSTRAS POSITIVAS PARA: & SECO E FRIO & $\begin{array}{c}\text { QUENTE E } \\
\text { CHUVOSO }\end{array}$ & $\begin{array}{c}\text { SECO E FRIO E QUENTE } \\
\text { E CHUVOSO }\end{array}$ \\
\hline Coliformes fecais OU Salmonella spp & 12 & 15 & 21 \\
Coliformes fecais E Salmonella spp & 1 & 1 & 4 \\
APENAS Coliformes fecais & 10 & 10 & 15 \\
APENAS Salmonella spp & 1 & 4 & 2 \\
NENHUMA AMOSTRA POSITIVA & 18 & 15 & 9 \\
\hline
\end{tabular}

Figura 8 - Porcentagem de pesqueiros positivos para coliformes fecais ou Salmonella spp, do total de 30 pesqueiros da região metropolitana de São Paulo estudados, independentemente do período analisado - São Paulo - set 2001 out 2001/fev 2002 - mar 2002

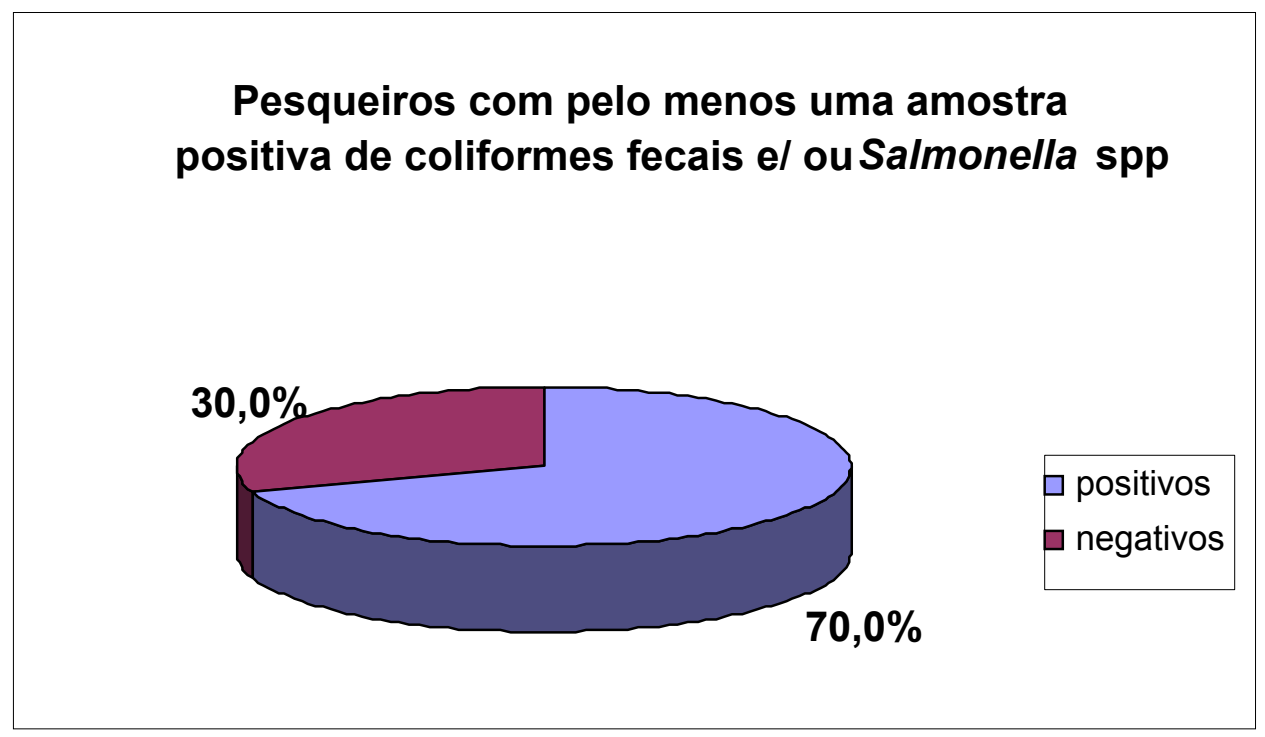

A Tabela 17 apresenta a distribuição durante os períodos seco e frio; chuvoso e quente, dos pesqueiros e amostras, de acordo com resultados positivos encontrados de 
coliformes fecais ou Salmonella spp encontrados nas amostras colhidas nos pesqueiros da região metropolitana de São Paulo.

Tabela 17 - Distribuição dos pesqueiros e das amostras, durante os períodos seco e frio; chuvoso e quente, e em ambos, de acordo com resultados positivos encontrados de coliformes fecais ou Salmonella spp encontrados nas amostras colhidas nos pesqueiros da região metropolitana de São Paulo - São Paulo - fev 2002 - mar 2002

\begin{tabular}{ccccccc}
\hline & \multicolumn{2}{c}{ PERÍODO SECO } & \multicolumn{2}{c}{ PERÍDO CHUVOSO } & \multicolumn{2}{c}{ TOTAL } \\
\hline & PESQUEIRO & AMOSTRA & PESQUEIRO & AMOSTRA & PESQUEIRO & AMOSTRA \\
Coliformes fecais & $36,7 \%$ & $21,1 \%$ & $36,7 \%$ & $18,9 \%$ & $63,3 \%$ & $20,0 \%$ \\
& $(11 / 30)$ & $(19 / 90)$ & $(11 / 30)$ & $(17 / 90)$ & $(19 / 30)$ & $(36 / 180)$ \\
Salmonella spp & $6,7 \%$ & $5,6 \%$ & $16,7 \%$ & $10,0 \%$ & $20,0 \%$ & $7,8 \%$ \\
& $(2 / 30)$ & $(5 / 90)$ & $(5 / 30)$ & $(9 / 90)$ & $(6 / 30)$ & $(14 / 180)$ \\
\hline
\end{tabular}

A Tabela 18 apresenta o comportamento, em relação a presença de coliformes fecais ou Salmonella spp em pelo menos uma amostra, do período seco e frio para o chuvoso e quente, dos pesqueiros da região metropolitana de São Paulo.

A Tabela 19 apresenta a presença de coliformes fecais, Salmonella spp, animais na propriedade ou agricultura, nos pesqueiros, considerando positivos os pesqueiros que apresentaram a presença ou ausência de coliformes fecais, Salmonella spp e animais ou agricultura.

Em relação a presença de coliformes fecais podemos observar que dos pesqueiros negativos que se tornaram positivos do período seco e frio para o período chuvoso e quente, seis $(75,0 \%)$ possuíam animais ou agricultura e dois $(25,0 \%)$ possuíam animais e agricultura. Dos pesqueiros positivos que se mantiveram positivos do período seco e frio para o período chuvoso e quente, três $(100,0 \%)$ possuíam animais ou plantações. Dos pesqueiros que não possuíam animais, cinco $(41,7 \%)$, se mantiveram negativos tanto no período seco e frio quanto no período chuvoso e quente. Dos pesqueiros que não possuíam agricultura, três $(23,1 \%)$, se mantiveram negativos tanto no período seco e frio quanto no período chuvoso e quente (Tabelas 18 e 19).

Em relação a presença de Salmonella spp podemos observar que dos pesqueiros negativos que se tornaram positivos do período seco e frio para o período chuvoso e quente, quatro $(100,0 \%)$ possuíam animais ou agricultura, dois $(50,0 \%)$ possuíam animais e agricultura. Dos pesqueiros positivos que se mantiveram positivos do período 
seco e frio para o período chuvoso e quente, um $(100,0 \%)$ possuía animais ou plantações. Dos pesqueiros que não possuíam animais, dez $(83,3 \%)$, se mantiveram negativos tanto no período seco e frio quanto no período chuvoso e quente. Dos pesqueiros que não possuíam agricultura, 12 (92,3\%), se mantiveram negativos tanto no período seco e frio quanto no período chuvoso e quente (Tabelas 18 e 19).

Em relação a presença de coliformes fecais ou Salmonella spp podemos observar que dos pesqueiros negativos que se tornaram positivos do período seco e frio para o período chuvoso e quente, sete $(77,8 \%)$ possuíam animais ou agricultura, dois $(22,2 \%)$ possuíam animais e agricultura. Dos pesqueiros positivos que se mantiveram positivos do período seco e frio para o período chuvoso e quente, seis $(100,0 \%)$ possuíam animais ou agricultura. Dos pesqueiros que possuíam animais, 25 (83,3\%), apresentaram algum resultado positivo no período seco e frio ou no período chuvoso e quente. Dos pesqueiros que possuíam agricultura, 24 (80,0\%), apresentaram algum resultado positivo no período seco e frio ou no período chuvoso e quente (Tabelas 18 e 19).

Tabela 18 - Comportamento dos pesqueiros estudados, da região metropolitana de São Paulo em relação à presença de coliformes fecais, Salmonella spp e coliformes fecais ou Salmonella spp que apresentaram pelo menos uma amostra positiva do período seco e frio para o chuvoso e quente - São Paulo - set 2001 - out 2001/fev 2002 - mar 2002

\begin{tabular}{|c|c|c|c|}
\hline COMPORTAMENTO DOS PESQUEIROS DO & COLIFORMES & Salmonella spp & COLIFORMES \\
\hline PERÍODO SECO E FRIO PARA O PERÍODO & FECAIS & & FECAIS OU \\
\hline CHUVOSO E QUENTE: & & & Salmonella spp \\
\hline Eram NEGATIVOS e se mantiveram & 11 & 24 & 9 \\
\hline \multicolumn{4}{|l|}{ NEGATIVOS } \\
\hline Eram NEGATIVOS e se tornaram POSITIVOS & 8 & 4 & 9 \\
\hline Eram POSITIVOS e se tornaram NEGATIVOS & 8 & 1 & 6 \\
\hline Eram POSITIVOS e se mantiveram POSITIVOS & 3 & 1 & 6 \\
\hline TOTAL DE PESQUEIROS & 30 & 30 & 30 \\
\hline
\end{tabular}


Tabela 19 - Presença de coliformes fecais, Salmonella spp, animais na propriedade e agricultura nos 30 pesqueiros da região metropolitana de São Paulo, considerando positivos, os que apresentaram a presença destes fatores - São Paulo - set 2001 - out 2001/fev 2002 - mar 2002

\begin{tabular}{|c|c|c|c|c|}
\hline PESQUEIRO & $\begin{array}{c}\text { COLIFORMES } \\
\text { FECAIS }\end{array}$ & Salmonella spp & $\begin{array}{c}\text { ANIMAIS NA } \\
\text { PROPRIEDADE }\end{array}$ & AGRICULTURA \\
\hline 1 & $\mathrm{~N}(*)$ & Positiva & Positiva & Positiva \\
\hline 2 & $\mathrm{~N}$ & $\mathrm{~N}$ & Positiva & Positiva \\
\hline 3 & $\mathrm{~N}$ & $\mathrm{~N}$ & $\mathrm{~N}$ & $\mathrm{~N}$ \\
\hline 4 & Positiva & $\mathrm{N}$ & Positiva & $\mathrm{N}$ \\
\hline 5 & Positiva & $\mathrm{N}$ & $\mathrm{N}$ & $\mathrm{N}$ \\
\hline 6 & Positiva & $\mathrm{N}$ & Positiva & $\mathrm{N}$ \\
\hline 7 & Positiva & $\mathrm{N}$ & Positiva & Positiva \\
\hline 8 & $\mathrm{~N}$ & $\mathrm{~N}$ & Positiva & Positiva \\
\hline 9 & Positiva & Positiva & $\mathrm{N}$ & Positiva \\
\hline 10 & $\mathrm{~N}$ & Positiva & $\mathrm{N}$ & Positiva \\
\hline 11 & $\mathrm{~N}$ & $\mathrm{~N}$ & $\mathrm{~N}$ & $\mathrm{~N}$ \\
\hline 12 & $\mathrm{~N}$ & $\mathrm{~N}$ & Positiva & Positiva \\
\hline 13 & Positiva & Positiva & Positiva & Positiva \\
\hline 14 & Positiva & $\mathrm{N}$ & $\mathrm{N}$ & $\mathrm{N}$ \\
\hline 15 & Positiva & Positiva & Positiva & $\mathrm{N}$ \\
\hline 16 & Positiva & $\mathrm{N}$ & $\mathrm{N}$ & $\mathrm{N}$ \\
\hline 17 & Positiva & $\mathrm{N}$ & Positiva & $\mathrm{N}$ \\
\hline 18 & Positiva & $\mathrm{N}$ & $\mathrm{N}$ & Positiva \\
\hline 19 & Positiva & Positiva & Positiva & Positiva \\
\hline 20 & Positiva & $\mathrm{N}$ & Positiva & Positiva \\
\hline 21 & Positiva & $\mathrm{N}$ & Positiva & Positiva \\
\hline 22 & Positiva & $\mathrm{N}$ & $\mathrm{N}$ & Positiva \\
\hline 23 & $\mathrm{~N}$ & $\mathrm{~N}$ & Positiva & Positiva \\
\hline 24 & Positiva & $\mathrm{N}$ & $\mathrm{N}$ & Positiva \\
\hline 25 & Positiva & $\mathrm{N}$ & Positiva & $\mathrm{N}$ \\
\hline 26 & Positiva & $\mathrm{N}$ & Positiva & $\mathrm{N}$ \\
\hline 27 & $\mathrm{~N}$ & $\mathrm{~N}$ & $\mathrm{~N}$ & Positiva \\
\hline 28 & $\mathrm{~N}$ & $\mathrm{~N}$ & Positiva & $\mathrm{N}$ \\
\hline 29 & $\mathrm{~N}$ & $\mathrm{~N}$ & $\mathrm{~N}$ & Positiva \\
\hline 30 & Positiva & $\mathrm{N}$ & Positiva & $\mathrm{N}$ \\
\hline
\end{tabular}

$(*)$ N: amostra negativa 
A Tabela 20 apresenta através dos valores de p (nível de significância), obtidos pelos testes estatísticos do Qui Quadrado e Fischer, a correlação entre quatro tipos de resultados encontrados: presença de coliformes fecais, presença de Salmonella spp, presença de coliformes fecais ou Samonella spp e presença de coliformes fecais e Samonella spp. Relacionados a quatro fatores ambientais e de entorno observados: período seco frio e período chuvoso quente; presença ou ausência de outros animais; presença ou ausência de agricultura; presença de outros animais e agricultura.

Tabela 20 - Valores obtidos do nível de significância, valor de p, aplicados os testes Qui Quadrado e Fischer, na verificação de associação entre período seco e frio; chuvoso e quente, presença ou ausência de outros animais na propriedade e agricultura e pesqueiros positivos para coliformes fecais, Salmonella spp, coliformes fecais e/ou Salmonella spp - São Paulo - set 2001 - out 2001/fev 2002 - mar 2002

\begin{tabular}{|c|c|c|c|c|}
\hline PESQUEIROS POSITIVOS & $\overline{\mathrm{SE} \mathrm{E} \mathrm{CH}}$ & $\begin{array}{c}\text { PRESENÇA DE } \\
\text { ANIMAIS }\end{array}$ & AGRICULTURA & $\begin{array}{c}\text { PRESENÇA DE } \\
\text { ANIMAIS E } \\
\text { AGRICULTURA }\end{array}$ \\
\hline COLIFORMES FECAIS & $\mathrm{p}=1$ & $\mathrm{p}=0,71$ & $\mathrm{p}=0,25$ & $\mathrm{p}=0,42$ \\
\hline Salmonella spp & $\mathrm{p}=0,42$ & $\mathrm{p}=1$ & $\mathrm{p}=0,19$ & $\mathrm{p}=0,63$ \\
\hline COLIFORMES FECAIS & $\mathrm{p}=0,43$ & $\mathrm{p}=1$ & $\mathrm{p}=0,69$ & $\mathrm{p}=0,14$ \\
\hline OU Samonella spp & & & & \\
\hline $\begin{array}{l}\text { COLIFORMES FECAIS } \\
\text { E Samonella spp }\end{array}$ & $\mathrm{p}=1$ & $\mathrm{p}=0,25$ & $\mathrm{p}=0,61$ & $\mathrm{p}=0,58$ \\
\hline
\end{tabular}

Os resultados obtidos pelo estudo das correlações não indicaram associação entre nenhum destes fatores observados, adotando-se nível de significância de $p<0,05$. 


\section{DISCUSSÃO}

\subsection{COLIFORMES TOTAIS}

Observou-se que $125(69,4 \%)$ das 180 amostras de peixes examinadas apresentaram coliformes totais entre $10^{2}$ e $10^{5} \mathrm{NMP} / \mathrm{g}$ e $25(83,3 \%)$ dos 30 pesqueiros avaliados apresentaram coliformes totais entre $10^{3}$ a $10^{6} \mathrm{NMP} / \mathrm{g}$.

Por não terem sido encontrados trabalhos que utilizassem metodologia similar a técnica de lavado superficial, utilizada no presente trabalho, os resultados obtidos foram comparados com os de trabalhos que se utilizaram de técnicas destrutivas para obtenção da alíquota mínima para detecção dos agentes estudados.

Almeida et al. (2002), em Cuiabá (MT), obtiveram em 96,6\% das 30 amostras de pintado (Pseudoplatystoma fasciatum) examinadas para coliformes totais, médias aritméticas de $8,4 \times 10^{4} \mathrm{NMP} / \mathrm{g}$ para aqueles oriundos de feiras livres e $8,4 \times 10^{3} \mathrm{NMP} / \mathrm{g}$ para aqueles oriundos de supermercados. Cardoso et al. (2003), em Goiânia (GO) encontraram contagem $>10^{3} \mathrm{UFC} / \mathrm{g}$ em $30,8 \%$ de 12 amostras de peixe resfriado e $>10^{3}$ UFC/g em 16,1\% de cinco amostras de peixe congelado. Classificando os pesqueiros do presente trabalho de acordo com a ocorrência de coliformes totais, 83,3\% das propriedades apresentaram contagens $>10^{4}$ e $100,0 \%$ maior que $>10^{3} \mathrm{NMP} / \mathrm{g}$. Apesar dos resultados de Almeida et al. (2002) e Cardoso et al. (2003) serem expressos em UFC/g é possível um confronto com o presente estudo apontando semelhanças. Em ambos nota-se tendência dos resultados para valores $>10^{3} \mathrm{NMP} / \mathrm{g}$.

Estes valores $>10^{3} \mathrm{NMP} / \mathrm{g}$ encontrados causam preocupação, uma vez que podem existir ainda diversos pontos de contaminação e multiplicação de microrganismos durante a produção, captura, transporte, armazenamento, processamento e comercialização até finalmente chegar ao consumidor. A qualidade microbiológica deste produto pode evidenciar a baixa qualidade higiênica desta matéria prima tanto que os autores citados classificaram o pescado estudado como sendo de baixa qualidade.

Os resultados obtidos para coliformes totais, em NMP/g das 180 amostras,

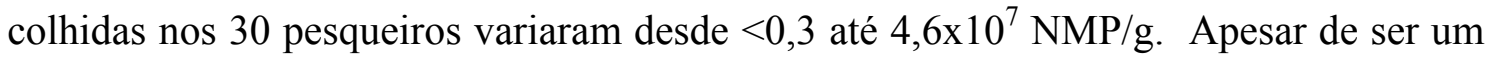
considerável intervalo de achados, são muito semelhantes aos achados na literatura. Almeida et al. (2002) estudando 30 amostras de pintados (Pseudoplatystoma fasciatum) comercializados em supermercados e feiras livres, em Cuiabá (MT), encontraram 
concentrações de coliformes totais entre $<0,3$ e 1,1×106 NMP/g. Dams et al. (1996) em

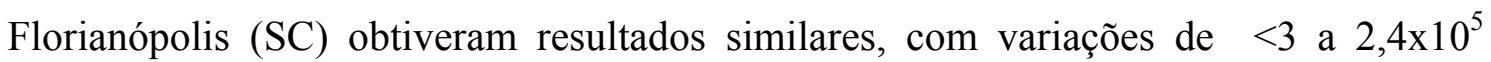
$\mathrm{NMP} / \mathrm{g}$ para pescado inteiro fresco, de $<3$ a $2,3 \times 10^{3} \mathrm{NMP} / \mathrm{g}$ para pescado congelado e de $4,0 \times 10^{2}$ a $2,0 \times 10^{5} \mathrm{NMP} / \mathrm{g}$ para filés. Para pescado congelado, Aquino et al. (1996), em Manaus (AM) encontraram variações entre $<10$ a 2,4x10 $\mathrm{UFC} / \mathrm{g}$. Cardoso et al. (2003), em Goiânia (GO), constataram contaminação por coliformes totais entre $<10$ a $4,6 \times 10^{4} \mathrm{UFC} / \mathrm{g}$ para peixe resfriado pronto para o consumo enquanto que para peixe congelada, variação de $<1,0 \times 10^{1}$ a $4,0 \times 10^{3} \mathrm{UFC} / \mathrm{g}$. Andrade et al. (2002) pesquisando coliformes totais em filés de peixe peruá (Balistes capriscus) em mercados do Rio de Janeiro, observaram variação de $0,3 \times 10^{3}$ a $3,0 \times 10^{6} \mathrm{UFC} / \mathrm{g}$ e para o peixe inteiro de $0,5 \times 10^{4}$ a $1,5 \times 10^{6} \mathrm{UFC} / \mathrm{g}$. Ao mesmo tempo que os resultados dos diferentes autores se repetem nota-se que o momento da cadeia produtiva no qual se faz a colheita do produto (produção ou distribuição/comercialização) para análise e o tipo de apresentação (inteiro, filés, etc.) e o método de conservação utilizado (refrigerado, congelado) proporciona diferenças na concentração de coliformes totais. É muito provável que ao mesmo tempo que a industrialização e/ou manufatura do peixe agrega valor e pode reduzir a contaminação primária, pode também agregar novos contaminantes, em especial quando há falhas nas práticas de fabricação e manipulação.

A literatura apresentada revela dados semelhantes aos encontrados neste trabalho, porém alguns autores encontraram também coliformes totais, em concentrações menores. Também deve-se levar em consideração que o presente estudo obteve resultados utilizando técnica do lavado superficial, enquanto os resultados dos autores citados foram obtidos por técnica de amostragem destrutiva.

Analisando os resultados semelhantes ao do presente trabalho, diferentes autores

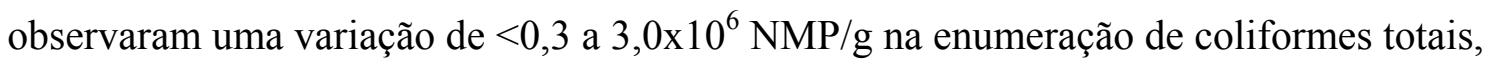
levando-se em conta que os peixes foram colhidos na fase de comercialização. No presente estudo, os peixes foram obtidos diretamente dos tanques de produção apresentando concentrações de coliformes totais muito semelhantes, com variações entre $<0,3$ e $4,6 \times 10^{7} \mathrm{NMP} / \mathrm{g}$.

Os coliformes totais são indicadores de qualidade higiênica, não apontando diretamente o contato do produto com fezes humana ou de animais, porém informa sobre o grau de poluição microbiana a que está exposto o alimento em estudo. Indiretamente informa sobre a qualidade das práticas de produção, ou seja, elevadas concentrações sinaliza que há necessidade de se rever os procedimentos operacionais 
para se identificar quais as causas de contaminação do produto. Apesar de não indicarem diretamente a presença de patógenos são importantes indicadores sobre o potencial de deterioração do produto e de sua vida de prateleira (AGNESE et al., 2001).

Alguns autores encontraram concentrações menores: Lira et al. (2001), variações desde $<3,0$ a $2,4 \times 10^{2} \mathrm{NMP} / \mathrm{g}$, estudando peixe serra (Pristis pectinata) inteiro fresco,

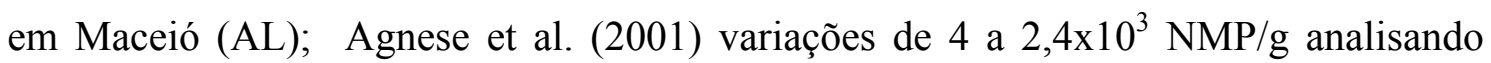
peixe fresco, em Seropédica (RJ); Möllerke et al. (2002) variações de $<3,0$ a $1,1 \times 10^{3}$ NMP/g em piava (Leporinus obtusidens) e pintado (Pimelodus maculatus) em Porto Alegre (RS). Castro et al. (2003), estudando 100 amostras do peixe curimã (Mugil lisa) encontraram desde ausência em um grama até 4,6×10² NMP/g; Nascimento, Filho e Taty (2001) analisando camarão salgado em feiras livres de São Luís (MA) encontraram

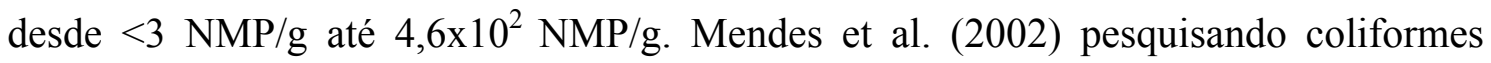
totais em camarão (Ltopenaeus vannamei) cru, em Pernambuco obtiveram desde a ausente em um grama até $4,3 \times 10^{2} \mathrm{NMP} / \mathrm{g}$.

Enquanto na literatura os achados variam de $<3$ a $2,4 \times 10^{3} \mathrm{NMP} / \mathrm{g}$, no presente estudo a variação foi de $<0,3$ até $4,6 \times 10^{7} \mathrm{NMP} / \mathrm{g}$. Esta constatação é preocupante uma vez que a matéria-prima (peixe colhido diretamente do tanque de produção), está com cargas microbianas bastante elevadas, o que expressa a baixa qualidade higiênica do peixe analisado.

Os autores citados obtiveram suas amostras na distribuição e comercialização do pescado e consideraram falhas no processamento, precárias condições de higiene e práticas deficientes de sanitização como prováveis causas dos elevados índices de coliformes totais. No presente estudo os peixes foram obtidos na fase anterior da cadeia produtiva, isto é, na produção não tendo recebido nenhum tipo de processamento nem manipulação. Confrontando estes resultados faz-se preocupante as concentrações de coliformes totais encontradas neste trabalho, cargas de até $10^{7} \mathrm{NMP} / \mathrm{g}$ de peixe, pois este ainda será processado antes de chegar até o consumidor.

Há autores que afirmam que o processamento é capaz de reduzir a carga microbiana do pescado. Mendes et al. (2002) observaram redução significativa com os procedimentos de pré-cozimento e descascamento do camarão. Também a lavagem com água clorada pode atuar positivamente. Mais uma vez reforça a necessidade de se implementar práticas e manejo adequados em todo o sistema produtivo. 
Vieira (2000) em Campina Grande (PB), estudou a contaminação por coliformes de 60 peixes na cadeia produtiva. Inicialmente obteve concentrações de 3,0 NMP/g para coliformes totais e fecais. Em filés congelados encontrou valores de 2,4 x $10^{3} \mathrm{NMP} / \mathrm{g}$. Vieira (2000) justifica tais achados como decorrentes de práticas deficientes em higiene por parte dos manipuladores na indústria, em especial nos procedimentos de filetagem e retirada da pele, etapas nas quais as amostras se apresentaram mais contaminadas.

$\mathrm{Na}$ detecção e no controle da contaminação em alimentos, deve-se sempre salientar a participação do manipulador, como fator de grande importância, uma vez que ele representa o principal elo na transmissão da contaminação microbiana. A maioria dos alimentos, particularmente aqueles de origem animal, estão sujeitos a contaminação por bactérias patogênicas, sendo o manipulador, aparentemente sadio, muitas vezes o veículo implicado (BARRETO; VIEIRA, 2003). Os manipuladores de alimentos são considerados importantes fontes de propagação, em função das características de seu trabalho e o contato direto com os alimentos e segundo a FAO/ OMS, eles constituem a segunda causa de toxiinfecção alimentar.

Assim sendo, mesmo que existam etapas que possam reduzir a contaminação microbiana, a presença elevada de coliformes totais já na matéria prima pode comprometer a qualidade do produto final, somando-se a isto a qualidade das práticas de manipulação posteriores, colocando em risco a saúde da população consumidora.

\subsection{COLIFORMES FECAIS}

Para coliformes fecais a variação dos resultados em NMP/g foi de (menor do que) $<0,1$ a $6,8 \times 10^{4} \mathrm{NMP} / \mathrm{g}$. Castro et al. (2003), estudando peixe inteiro curimã (Mugil lisa), encontraram desde ausência em um grama até 4,6 $10^{2} \mathrm{NMP} / \mathrm{g}$. Aquino et al. (1996) em Manaus, analisando pescado congelado, encontraram variações de 3,6 a $2,4 \times 10^{5}$ UFC/g. Silva et al. (2002) em Maceió (AL), enumerando coliformes fecais em peixes de feiras livres e supermercados observaram contagens variando de $1,5 \times 10^{2}$ a $1,1 \times 10^{7} \mathrm{NMP} / \mathrm{g}$. A literatura sugere que há uma contaminação crescente do pescado conforme este percorre a cadeia produtiva, haja vista as concentrações de coliformes fecais encontradas por Silva et al. (2002) em peixes na distribuição de varejo em Maceió.

Em contrapartida Agnese et al. (2001), no município de Seropédica (RJ) avaliando peixe fresco no varejo encontraram variação de $<3,0$ a 2,3x10 NMP/g e 
Almeida et al. (2002) estudando 30 amostras de pintados (Pseudoplatystoma fasciatum) de Cuiabá (MT), obtiveram para coliformes fecais uma variação desde ausência até $1,1 \times 10^{3} \mathrm{NMP} / \mathrm{g}$. Também Möllerke et al. (2002) estudando piava (Leporinus obtusidens) e pintado (Pimelodus maculatus) em Porto Alegre (RS), encontraram

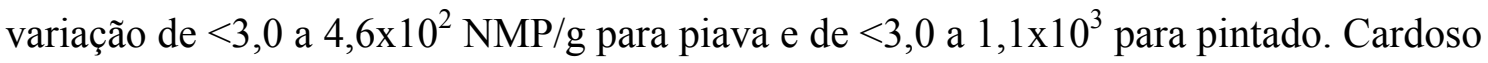
et al. (2003), em Goiânia (GO), pesquisando coliformes fecais em carne de peixe resfriada, encontraram concentrações variando de $<10$ a $1,2 \times 10^{3} \mathrm{UFC} / \mathrm{g}$. Nascimento, Filho e Taty (2001) pesquisando coliformes em 18 amostras de camarão salgado em São Luís (MA) obtiveram para coliformes fecais desde $<3,0$ até $1,5 \times 10^{2} \mathrm{NMP} / \mathrm{g}$. A semelhança do que foi descrito para enumeração de coliformes totais, deve-se levar em consideração que o presente estudo obteve resultados utilizando técnica do lavado superficial, enquanto os resultados dos autores citados foram obtidos por técnica de amostragem destrutiva.

A literatura estudada refere uma ocorrência de coliformes fecais variando desde ausência até $2,4 \times 10^{5} \mathrm{NMP} / \mathrm{g}$, enquanto que no presente estudo observou-se variações entre $<0,1$ a $6,8 \times 10^{4} \mathrm{NMP} / \mathrm{g}$. É necessário considerar que os autores pesquisaram peixes já na comercialização e neste trabalho na produção, podendo ser este um fator que explica a diferença dos resultados obtidos.

Os coliformes que estão em elevadas concentrações nas fezes dos homens e animais de sangue quente, não existem naturalmente nas águas a não ser em número muito reduzido, porém em águas poluídas a sua ocorrência pode variar (CARDOSO et al., 2001).

A presença de coliformes fecais e em diferentes concentrações indicam que, de alguma forma, a água está sendo contaminada. No caso dos pesqueiros com amostras positivas, existe alguma fonte desta matéria orgânica contendo fezes de animais ou do próprio homem comprometendo a qualidade desse pescado.

O Código de Vigilância Sanitária-Ministério da Saúde-DNVSA- Portaria n 451 , de 19/09/97, determina como padrão máximo aceitável para coliformes fecais em Pescados e Produtos de Pesca o valor de $10^{2} \mathrm{NMP} / \mathrm{g}$. Neste trabalho todas as amostras que apresentaram resultados com valores igual ou acima de $10^{2} \mathrm{NMP} / \mathrm{g}$ foram consideradas "amostras positivas" e em desacordo com a legislação; da mesma forma, os pesqueiros que apresentaram pelo menos uma amostra em desacordo com esta legislação foram denominados "pesqueiros positivos". 
Considerando a distribuição dos resultados de acordo com o número de amostras positivas para coliformes fecais, observou-se que $36(20,0 \%)$ destas apresentaram resultados em desacordo com a legislação.

Castro et al. (2003), estudando 100 amostras do peixe curimã (Mugil lisa), encontrou 20\% das amostras em desacordo com a legislação. Muratori (1994) em Teresina (PI) estudando 450 amostras de "branquinhas" (Curimatus ciliatus) também encontrou $20 \%$ das amostras em desacordo com a legislação. Aquino et al. (1996) em Manaus encontraram 73,4\% (em 45 amostras) em desacordo com a legislação. Silva et al. (2002) avaliando a qualidade microbiológica de 60 amostras de pescado coletadas em feiras livres e supermercados da cidade de Maceió (AL), observaram que 51 (85\%) apresentaram coliformes fecais em desacordo com a legislação. Gaspar et al. (1997) estudaram 24 amostras de peixes frescos em Fortaleza (CE) e constataram 58,3\% das estavam fora dos padrões para coliformes fecais. Möllerke et al. (2002) pesquisando coliformes totais e fecais em 43 amostras de piava (Leporinus obtusidens) e 43 de pintado (Pimelodus maculatus) em Porto Alegre (RS), encontraram fora dos padrões 4,65\% das amostras de piava, e 11,62\% das amostras de pintado. Machado et al. (2001), estudando a ocorrência de contaminação orgânica no estuário de Cananéia (SP), como subsídio para cultivo da ostra do mangue, encontraram níveis de coliformes fecais acima do padrão em $4(10,8 \%)$ de 41 amostras, em 1996 e em 19 (27,5\%) de 69 amostras em 1997.

Nos levantamentos citados, a variação de resultados em desacordo com a legislação está entre $4,65 \%$ e $85 \%$ das amostras. Pôde se observar uma variação muito ampla de ocorrência de coliformes fecais. O que se pode interpretar é que são várias as práticas não adequadas desde a produção até a comercialização do pescado que pode permitir o seu contato com fezes.

$\mathrm{Na}$ piscicultura as vias de contaminação por coliformes fecais geralmente ocorrem pela água de abastecimento contaminada por fezes, por resíduos de adubos orgânicos ou por dejetos lançados nos tanques de criação. Elevados índices de coliformes totais e fecais no pescado recém capturado, indicam a presença de uma fonte poluidora recente e risco deste alimento provocar infecções ou intoxicações no consumidor (NASCIMENTO et al., 2001).

Considerando a distribuição dos pesqueiros positivos em relação ao número de amostras positivas para coliformes fecais, nove (30,0\%) apresentaram uma amostra positiva; cinco $(16,7 \%)$ duas amostras positivas e quatro $(13,3 \%)$ três amostras 
positivas, sendo que 19 pesqueiros $(63,3 \%)$ apresentaram pelo menos uma amostra positiva.

Observa-se que das 180 amostras examinadas, 20\% foram positivas para coliformes fecais porém considerando os 30 pesqueiros estudados, 63,3\% apresentaram pelo menos uma amostra positiva. Isto demonstra o elevado número de propriedades onde foi possível detectar coliformes fecais com resultados em desacordo com a legislação e portanto produzindo peixes com baixa qualidade higiênica, higiênicosanitária e impróprios para o consumo humano.

O problema da contaminação das águas por excretos humanos ou de origem animal é a provável causa dos achados neste trabalho. A vigilância rotineira bacteriológica dos sistemas de abastecimento e de seus produtos é indispensável para proteger diretamente a qualidade da água de consumo humano direto e também a qualidade dos produtos cujas produções e preparações se utilizam de água (CARDOSO et al., 2001).

\subsection{Salmonella spp}

Em relação à pesquisa de Salmonella spp, obteve-se presença em $14(7,8 \%)$ amostras positivas. Cardoso et al. (2003), em Goiânia, encontraram Salmonella spp em três $(4,3 \%)$ amostras. Batista e Meinret (1995) relataram a presença de Salmonella spp em peixes de peixarias em 8,3\% na Paraíba e em 2,0\% em Santa Catarina. Muratori (1994), em Teresina (PI), estudou 450 "branquinhas" (Curimatus ciliatus) e verificou presença de Salmonella spp em 6,6\% das amostras. Vieira (2000) encontrou Salmonella spp em $8,3 \%$ de 60 amostras de filés congelados.

Nota-se uma variação de $2,0 \%$ a $8,3 \%$, na freqüência de ocorrência de Salmonella spp entre os autores estudados, dentro da qual se inclui a ocorrência neste trabalho de $7,8 \%$. A presença desta bactéria representa um risco potencial a saúde do consumidor, por ser um agente patogênico e informa ainda que existem falhas em algum momento das práticas que compõem a cadeia produtiva.

Outros autores encontraram freqüências de ocorrências da presença de Salmonella spp maiores do que neste trabalho. Pode-se citar Almeida et al. (2002) que encontraram Salmonella spp em $5(16,7 \%)$ de 30 pintados (Pseudoplatystoma fasciatum) colhidos em supermercados e feiras livres em Cuiabá (MT). Hoffmann et al. (1999) constataram na cidade de São José do Rio Preto (SP) a presença de Salmonella 
spp em 36,4\% de um total de 11 amostras de pescado. Silva et al. (2002) avaliando a qualidade microbiológica de 60 amostras de pescado de feiras livres e supermercados em Maceió (AL), encontraran 15 (25\%) das amostras com presença de Salmonella spp. Dams (1996) Avaliou a qualidade sanitária de pescadinha (Cyanoscian striatus) e identificou Salmonella spp em $80 \%$ das amostras de filé e $40 \%$ do pescado inteiro "in natura". Lima e Reis (2002) estudando amostras de pacu (Piaractus mesopotamicus) de rio e cultivado, comercializados no município de Cuiabá (MT). Das 20 amostras de pacu analisadas, sete $(35,0 \%)$ evidenciaram a presença de Salmonella spp. Observa-se que duas $(28,5 \%)$ eram oriundas de rio e cinco $(71,4 \%)$ eram de tanque (coletados em criadouro).

Estes autores citados encontraram valores de presença de variando de 16,7\% a $80,0 \%$, valores superiores em relação aos encontrados neste estudo 7,8\%. O que observamos neste caso, semelhante ao ocorrido em relação ao estudo de coliformes fecais é que os dados dos autores citados referem-se a amostras coletadas no varejo, no ponto de comercialização, enquanto que o presente trabalho pesquisou o produto em sua origem, na produção.

Discute-se que a passagem das etapas da cadeia produtiva, formas de processamento, transporte, armazenamento distribuição e comercilização, oferecem oportunidades para contaminações cruzadas. Dams et al. (1995) em Florianópolis, obtiveram em $20 \%$ das amostras de peixe fresco a presença de Salmonella spp e em $40 \%$ de peixe inteiro congelado e $80 \%$ em filés congelados. Neste trabalho observou-se o aumento da frequência de ocorrência de Salmonella spp no processamento do pescado.

Pimentel e Panetta (2003) estudando condições higiênicas do gelo utilizado na conservação de pescado em supermercados da Grande São Paulo atribuíram os resultados positivos referentes à Salmonella spp a contaminação ocorrendo nos convés de barcos pesqueiros, porões, águas contaminadas e manipulação nos entrepostos.

Observa-se que em todos os estudos descritos, independentemente do ponto da cadeia de produção estudado, a qualidade sanitária das amostras de pescado analisadas foi deficiente, estando o pescado impróprio para o consumo e colocando em risco a saúde da população.

Neste trabalho, a ocorrência de Salmonella spp nos peixes pode ser atribuída por contaminação das águas dos tanques. Sendo Salmonella spp uma bactéria fracamente competidora, o seu isolamento em formas viáveis significa contato com fontes 
poluidoras recentes ou persistentes. Estas fontes poluidoras, poderíam ser fezes de animais domésticos ou silvestres que tem contato direto ou indireto com os tanques e com os peixes ou práticas de adubação utilizadas pela agricultura, com fezes de animais, no entorno dos tanques. Estes dejetos poderíam ser carreados para dentro dos tanques também pela ação da água de chuva.

Alguns autores, entretanto, não encontraram o agente em nenhuma das amostras estudadas. Martins, Vaz e Minozzo (2002) em Toledo (PR) analisando filés de tilápia e carpa em "pesque-pagues", não encontraram Salmonella spp. Castro et al. (2003), de 100 amostras do peixe curimã (Mugil lisa), relatou também ausência de Salmonella spp. Aquino et al. (1996) em Manaus estudando 45 amostras de pescado congelado, não detectaram Salmonella spp. Mouchrek et al. (2003) em Manaus (AM) avaliaram 15 amostras de pirarucu seco salgado (Arapaima gigas) de feiras-livres, verificando-se ausência de Salmonella spp em todas as amostras. Mendes et al. (2002) em Pernambuco estudaram camarão (Ltopenaeus vannamei) defumado, observando ausência de Salmonella spp em 100\% das amostras analisadas.

Observando os resultados encontrados pelos diversos autores, pode se inferir que ou o pescado não foi contaminado em nenhuma etapa, ou processos tecnológicos de conservação como salga e defumação foram capazes de inativar a viabilidade de agentes supostamente presentes. Novamente salienta-se a importância das boas práticas de produção e fabricação em toda cadeia até o consumidor final, prevenindo, reduzindo ou eliminando a ocorrência de agentes patogênicos.

O Código de Vigilância Sanitária - Ministério da Saúde- DNVSA- Portaria $n^{\circ}$ 451, de 19/09/97, estabelece como padrão microbiológico para Salmonella spp, a ausência em 25g. Do total de 180 amostras examinadas neste trabalho, 7,8\% foram positivas para Salmonella spp, porém considerando os 30 pesqueiros estudados, $20,0 \%$ apresentaram pelo menos uma amostra positiva. Isto demonstra que $20 \%$ das propriedades estudadas continham na sua produção peixes impróprios para o consumo humano, e que em algum momento as águas estiveram ou foram contaminadas com matéria fecal humana ou animal.

\subsection{COLIFORMES FECAIS OU Salmonella spp}

Foi relacionada a presença de coliformes fecais ou Salmonella spp nos 30 pesqueiros estudados. Os pesqueiros que apresentaram pelo menos uma amostra 
positiva, em desacordo com a legislação foram considerados como propriedades positivas.

Observou-se que $21(70,0 \%)$ dos pesqueiros apresentaram pelo menos uma amostra positiva ou para coliformes fecais ou Salmonella spp.

Dos 30 pesqueiros estudados, em $70 \%$ foram encontrados indicadores da condição higiênico-sanitária ou patógenos em desacordo com os padrões vigentes.

Esta ocorrência pode ter como fatores contribuintes e mesmo determinantes como afirma Alexandrino (1998), que na aquicultura brasileira não há o necessário controle sanitário sobre a atividade, o que tem colaborado com a produção de pescado com qualidade duvidosa.

\subsection{PRESENÇA DE ANIMAIS, AGRICULTURA E PERÍODOS DO ANO}

Foram estudadas as correlações entre a presença de coliformes fecais e Salmonella spp com a presença de, animais ou agricultura, nos 30 pesqueiros da região metropolitana de São Paulo, durante os períodos seco e frio, quente e chuvoso, estudados.

Mouchrek et al. (2003) afirmam que a qualidade microbiológica do pescado pode variar segundo estações do ano, idade e local de captura. Dependendo do local e do período de colheita das amostras, ou seja, próxima ou distante da fonte poluidora, pode existir uma grande variação da carga microbiana de uma coleção de águas. (NASCIMENTO et al., 2001).

Estudou-se o comportamento dos pesqueiros negativos, para a presença de coliformes fecais, que se tornaram positivos do período seco e frio para o período chuvoso e quente. Durante o período chuvoso, os dejetos de animais e os resíduos orgânicos de agricultura podem chegar mais facilmente, levados pela chuva, nos tanques de criação, trazendo matéria orgânica e enterobactérias.

Observou-se que, $20(75,0 \%)$ pesqueiros que possuíam criações de animais ou agricultura apresentaram-se negativos para coliformes fecais, no período seco e frio porém tornaram-se positivos no período chuvoso e quente.

Ressalta-se que que foram analisadas apenas 3 amostras por propriedade em cada um dos períodos e que não foi possível, com este baixo número de amostras, inferir causalidade com significância estatística, porém pode-se suspeitar da forte 
influência das chuvas na disseminação de agentes entéricos, assim como de outros microrganismos livremente distribuídos no ambiente.

Observou-se que três $(100,0 \%)$ pesqueiros, que se mantiveram positivos em ambos os períodos, possuíam animais ou agricultura. Dos pesqueiros que não possuíam animais, cinco $(41,7 \%)$, se mantiveram negativos para coliformes fecais, em ambos os períodos e dos pesqueiros que não possuíam agricultura, três $(23,1 \%)$, também se mantiveram negativos.

Em relação a presença de Salmonella spp, quatro (100,0\%) pesqueiros negativos se tornaram positivos do período seco e frio para o período chuvoso e quente, e possuíam animais ou agricultura e dois $(50,0 \%)$ possuíam animais e agricultura. A semelhança do que foi descrito para coliformes fecais, a ocorrência de chuva e a elevação da temperatura, pode ter possibilitado a contaminação das águas dos tanques e consequentemente a contaminação dos peixes.

Dos pesqueiros positivos que se mantiveram positivos do período seco e frio para o período chuvoso e quente, um $(100,0 \%)$ possuía animais ou agricultura. Dos pesqueiros que não possuíam animais, dez $(83,3 \%)$, se mantiveram negativos em ambos os períodos e dos pesqueiros que não possuíam agricultura, 12 (92,3\%), também se mantiveram negativos.

Considerando a presença de coliformes fecais ou Salmonella spp, sete $(77,8 \%)$ pesqueiros, que apresentavam resultados negativos no período seco e frio e positivos no período chuvoso e quente, possuíam animais ou agricultura, confirmando a tendência dos dados já discutidos para coliformes fecais e Salmonella spp em relação a chuva como fator de contribuição para veiculação destas bactérias para os tanques contaminando os peixes. Outros dados reforçam o fato relatado pois, seis $(100,0 \%)$ dos pesqueiros positivos que se mantiveram positivos para coliformes fecais ou Salmonella spp em ambos os períodos, possuíam animais ou agricultura, 25 (83,3\%) dos pesqueiros que possuíam animais, apresentaram pelo menos um resultado positivo em algum dos períodos e $24(80,0 \%)$ dos pesqueiros que possuíam agricultura também apresentaram algum resultado positivo considerando ambos os períodos.

Estes dados mostram que as bactérias encontradas, originárias do intestino do homem e de animais de sangue quente (CASTRO et al., 2003) nos peixes, podem ser um indicador de contaminação por dejetos orgânicos advindos destas criações de animais e agricultura realizadas no entorno dos tanques de criação. 
Martins, Vaz e Minozzo (2002) em Toledo (PR), avaliando filé de tilápia e carpa eviscerada de seis "pesque-pagues" no período quente de janeiro a abril de 2001 e dois no período frio de agosto de 2001, observaram que no período frio houve redução na carga microbiana, e relacionaram tal fato com a queda de temperatura da água de cultivo. Os autores defendem que existe uma relação entre qualidade microbiológica do pescado e as práticas de manejo, desde produção, captura e processamento e que a temperatura da água interfere na carga microbiana inicial do pescado. Os coliformes fecais e a Salmonella spp. tem o seu desenvolvimento ideal em temperaturas de $45^{\circ} \mathrm{C}$ e $38^{\circ} \mathrm{C}$, respectivamente (FRANCO, 1996), sendo que quanto mais alta a temperatura do tanque melhor o desenvolvimento destes microrganismos nestas águas, uma vez que a temperatura destes tanques dificilmente ultrapassará $45^{\circ} \mathrm{C}$, nas condições climáticas da região estudada.

Machado et al. (2001) em Cananéia (SP), estudando 37 amostras de ostras em relação a coliformes fecais, em 1996 não detectaram ocorrências em desacordo com a legislação no período de inverno porém na primavera obtiveram quatro resultados positivos. Em 1997 de um total 68 amostras, 19 ocorrências sendo sete (36,8\%) no verão, sete $(36,8 \%)$ na primavera, duas $(10,5 \%)$ no outono e três $(15,8 \%)$ no inverno, demonstrando uma concentração de resultados positivos nos períodos mais quentes e chuvosos.

Em nenhuma das 16 correlações estudadas foi observada associação entre os fatores estudados, adotando-se nível de significância $p<0,05$. Correlacionou-se os quatro tipos de resultados encontrados: presença de coliformes fecais, presença de Salmonella spp, presença de coliformes fecais ou Samonella spp e presença de coliformes fecais e Samonella spp. com os quatro fatores ambientais e de entorno observados: período seco e frio ou chuvoso e quente; presença ou ausência de animais; presença ou ausência de agricultura e presença ou ausência de animais e agricultura.

Machado (1989) no Ceará, pesquisou 579 amostras de cauda de lagosta, de oito indústrias beneficiadoras, no período de julho de 1985 a junho de 1986. O autor observou que, os meses que apresentaram maior quantidade de coliformes fecais foram de julho a agosto e de novembro a dezembro, coincidindo com o período de férias escolares quando a freqüência da lagoa aumenta, não sendo notada nenhuma relação com os períodos chuvosos.

A presença de criação de animais e o manejo de áreas agrícolas no entorno dos cultivos de peixes representam risco de contaminação das águas e de seus produtos. A 
ausência de uma diferença significativa em relação aos diferentes períodos estudados, seco e frio; chuvoso e quente pode ser decorrente da elevada contaminação notada igualmente em ambos os períodos estudados (VIEIRA; OLIVEIRA, 2001), sugerindo que estas estão igualmente poluídas com dejetos fecais, ou pode ser também explicada como decorrência do baixo número de amostras representativas de cada propriedade estudada nos diferentes períodos.

A presença de enterobactérias no alimento indicam contaminação fecal e risco potencial a saúde (MÖLLERKE et al, 2002). É certo também que estas bactérias são destruídas pelo cozimento doméstico, entretanto contaminações cruzadas entre alimentos podem ocorrer. Pode-se através de ações preventivas, de boas práticas de produção, manipulação e de controle, manter o pescado em condições de consumo até a mesa do consumidor.

Definir estratégias, através de um Programa de Manejo em Saúde para pesqueiros comerciais, onde o planejamento do manejo zoosanitário, possa proporcionar a oferta de um produto com qualidade e segurança para o consumidor através da implementação de Boas práticas na produção piscícola e Procedimentos padrão de higiene operacional, se faz indispensável.

Torna-se necessário implementar medidas racionais que dêem condições de implantar uma política de ecodesenvolvimento. Que seja dada ênfases aos critérios de qualidade para o ambiente aquático que garantam diretamente a proteção e preservação dos ecossistemas regionais e indiretamente a proteção da saúde do homem. Com a mudança das práticas que levaram a esta situação encontrada, mobilizando os diversos setores sociais, públicos e econômicos envolvidos na questão para que viabilizem a implementação efetiva da melhoria dos procedimentos e das práticas operacionais.

$\mathrm{Na}$ educação para saúde é fundamental uma aprendizagem que vise modificar favoravelmente as atitudes e influenciar o comportamento do indivíduo e da comunidade às práticas de saúde. 


\section{CONCLUSÕES}

Foi comprovada a ocorrência de coliformes totais, fecais e Salmonella spp em tilápias dos pesqueiros da região metropolitana de São Paulo.

Nos pesqueiros estudados foram encontrados peixes contaminados por estes microrganismos estando impróprios para o consumo humano "in natura".

Não foi identificada associação estatística entre a ocorrência de coliformes totais, fecais e Salmonella spp, com os diferentes períodos, seco e frio, chuvoso e quente estudados e nem com a presença de criação de outros animais ou de agricultura no entorno dos tanques.

Faz-se necessária a conscientização dos empresários desta atividade em relação a existência de contaminações de natureza fecal, incluindo-se a presença de enteropatógenos, Salmonella spp destes perigos e que a manutenção desta forma de produção pode trazer prejuízos ao consumidor.

É de fundamental importância que a fiscalização embasada nos dados científicos, gerem regulamentação para esta atividade e tomem ações imediatas exigindo boas práticas de produção piscícola e monitoramento do pescado produzido pelos pesqueiros, para salvaguardar a saúde pública. 


\section{REFERÊNCIAS}

AGNESE, A. P.; OLIVEIRA, V. M.; SILVA, P. P. O.; SILVA, P. P. O.; OLIVEIRA, G. A. Contagem de bactérias heterotróficas aeróbias mesófilas e enumeração de coliformes totais e fecais, em peixes frescos comercializados no município de Seropédica - RJ. Hig. Aliment., v. 15, n. 88, p. 67-70, set. 2001.

ALEXANDRINO, A. C. Prevenção de Doenças em piscicultura. Boletim Técnico do Instituto de Pesca, n. 23, p. 45, 1998.

ALEXANDRINO, A. C.; OKUMURA, M. P. M.; BALDASSI, L.; ARAUJO, A. P.; GUENKA, A. Ocorrência de Aeromonas hydrophila em trutas arco-íris (Oncorhynchus mykiss). Boletim do Instituto de Pesca. São Paulo. 1999.

ALMEIDA, E. S.; SIGARINI, C. O.; RIBEIRO, J. N.; DELMONDES, E. C.; STELATTO, E; ARAÚJO JR., A. Características microbiológicas de "Pintado" (Pseudoplatystoma fasciatum) comercializado em supermercados e feira livre, no município de Cuiabá - MT. Hig. Aliment., v. 16, n. 99, p. 84-88, ago. 2002.

ALMEIDA F. O., E. S.; LINDNER, A. L.; SALES, K. G.; EUSTÁQUIO, E. ; STELLATO, E.; RIBEIRO, J. N. Avaliação microbiana de pescado (pintado), proveniente da região do Pantanal Matogrossense, comercializado com e sem refrigeração, no município de Cuiabá - MT, quanto a presença de patógenos de importância em saúde pública. Hig. Aliment., v. 15, n. 80/81, p. 144, ago. 2001.

ALVES, C. L.; CARVALHO, F. L. N.; GUERRA, C. G.; ARAÚJO, W. M. C. Comercialização de pescado no Distrito Federal: avaliação das condições. Hig. Aliment., v. 16, n. 102/103, p. 41-49, nov./dez. 2002.

ANDRADE, F. S. V.; CARNEIRO, M. J. M.; CORDEIRO, C. A. M. Avaliação sensorial e microbiológica do peruá (Balistes capriscus) capturado na região norte fluminense e comercializado no mercado de Campos dos Goytacazes - RJ. Hig. Aliment., v. 16, n. 99, p.70-74, ago. 2002.

ANVISA. Resolução RDC n. 12, 2 jan. 2001. Aprova o regulamento técnico sobre padrões microbiológicos para alimentos. Disponível em: $<$ http: //www. agricultura.gov.br>. Acesso em: 10 set. 2003.

ARAUJO, V.; FANG, G.; GUERRANT, R. L. Diarréias hospitalares: Nosocomial diarrhea. ACM arq. catarin. Med., v. 21, n. 2/3, p.95-100, abr./set. 1992.

BARRETO, N. S. E.; VIEIRA, R. H. S. F. Investigação sobre possíveis portadores de Staphylococcus aureus em duas indústrias de pesca. Hig. Aliment., v. 17, n. 104/105, p. 49-57, jan.-fev. 2003.

BARROS, V. R. M.; PAVIA, P. C.; PANETTA, J. C. Salmonella spp: sua transmissão através dos alimentos. Hig. Aliment., v. 16, n. 94, p. 15-19, mar. 2002. 
BATISTA, C. R. V.; MEINRET, E. M. Incidência de Salmonella sp. em sardinha (Sardinella brasiliensis, Steindachner, 1798) refrigerada. In: ENCONTRO NACIONAL DE Analistas de Alimentos, 9., 1995, João Pessoa. Anais... Universidade Federal de Santa Catarina, 1995.

BOZANO, G. L. N.; RODRIGUES, S. R. M.; CASEIRO, A. C. Desempenho da tilápia nilótica Oreochromis niloticus (L.) em gaiolas de pequeno volume. Sci. agric., out./dez. 1999 , v. 56, n. 4, p. 819-825.

BRASIL. Ministério da Agricultura. Portaria n. 368 de 10 de setembro de 1977. Aprova Regulamento Técnico sobre as Condições Higiênico-sanitárias e de Boas Práticas de Fabricação para Estabelecimentos Elaboradores/Industrializadores de Alimentos. Brasília (DF), 1997. Disponível em: http://www.agricultura.gov.br. Acesso em 10 set. 2003.

BRASIL. Ministério da Saúde. Secretaria de Vigilância Sanitária. Portaria n. ${ }^{\circ} 326$ de 01 de agosto de 1977. Aprova Regulamento Técnico para Fixação das Condições Higiênico-sanitárias e de Boas Práticas de Fabricação para Estabelecimentos Produtores/Industrializadores de Alimentos. Brasília (DF), 1997. Disponível em: http://www.saude.gov.br. Acesso em 10 set. 2003.

BRASIL. Ministério da Agricultura. Portaria n. ${ }^{\circ} 185$ de 13 de maio de 1997. Aprova Regulamento Técnico de Identidade e Qualidade de Peixe Fresco (inteiro e eviscerado). Brasília (DF), 1997. Disponível em: http://www.agricultura.gov.br. Acesso em 10 set. 2003.

BRASIL. Ministério da Agricultura/ Ministérios da Saúde. Resolução CISA n. ${ }^{\circ} 10$ de 13 de julho de 1984. Instituída pela Portaria interministerial MS/MA n. ${ }^{\circ} 01$ de 02 de fevereiro de 1982, 13 de julho de 1984. Brasília (DF), 1984. Disponível em: http://www.agricultura.gov.br. Acesso em 10 set. 2003

BRASIL. Ministério da Agricultura. Departamento de Produtos de Origem Animal. Decreto n. ${ }^{\circ} 1255$ de 25 de junho de 1962. Altera Regulamento de Inspeção Industrial e Sanitária de Produtos de Origem Animal. Rio de Janeiro (RJ), 1962. Disponível em: http://www.agricultura.gov.br. Acesso em 10 set. 2003

BRASIL. Ministério da Agricultura. Departamento de Produtos de Origem Animal. Decreto n. ${ }^{o} 30691$ de 29 de junho de 1952. Aprova o Regulamento da Inspeção Industrial e Sanitária de Produtos de Origem Animal. Rio de Janeiro (RJ), 1952. Disponível em: http://www.agricultura.gov.br. Acesso em 10 set. 2003

BRASIL. Ministério da Agricultura, do Abastecimento e da Reforma Agrária. Secretaria Nacional de Defesa Agropecuária. Departamento Nacional de Defesa Animal. Coordenação Geral de Laboratório Animal. Métodos de análise microbiológica para alimentos. 2. ed. Brasília: Ministério da Agricultura, 1991/ 1992. paginação irregular. Disponível em: http://www.agricultura.gov.br. Acesso em 10 set. 2003

CAMPOS, J.; BRISEIDA. Aislamiento de las principales bacterias contaminantes en carnes de pescado que se expenden en mercados de Santa Cruz. 55 f. Tese 
Facultad de Veterinaria y Zootecnia, Universidad Autonoma Gabriel Rene Moreno, Santa Cruz de la Sierra, 1996.

CARBERRY, J.; HANLEY, F. Commercial intensive tilapia culture in Jamaica. In: SIMPOSIO CENTROAMERICANO DE ACUACULTURA, 4., 1997, Tegucigalpa. Anais... Cultivo sustenible de camarón y tilapia. Tegucigalpa: Asociación Nacional de Acuicultores de Honduras and The Latin American Chapter of the World Aquaculture Society, 1997. p. 64-67.

CARDOSO, A. L. P.; TESSARI, E. N. C.; CASTRO, A. G. M.; KANASHIRO, A. M. I. A técnica de membrana filtrante, aplicada ao estudo bacteriológico da água de rede de abastecimento, utilizada pela população de Descalvado, SP. Hig. Aliment., v. 15, n. 82, p. 33-38, mar. 2001.

CARDOSO, A. L. P.; TESSARI, E. N. C.; CASTRO, A. G. M.; KANASHIRO, A. M. I.; ZANATTA, G. F. Incidência de coliformes e Salmonella sp. Em água proveniente de abatedouro avícola. Hig. Aliment., v. 17, n. 111, p. 73-78, ago. 2003.

CARDOSO, N. L. C.; ANDRÉ, M. C. D. P. B.; SERAFINI, A. B. Avaliação microbiológica de carne de peixe comercializada em supermercados da cidade de Goiânia-GO. Hig. Aliment., v. 17, n. 109, p. 81-87, jun. 2003.

CARRERA VARA, J. A.; CABALLERO TORRES, A.; LENGOMÍN FERNÁNDEZ, M. E. Vigilancia de Staphylococcus y Salmonella en alimentos. Rev. Cuba. Aliment. Nutr., v. 12, n. 1, p. 16-19, 1998.

CASTILLO CAMPO, L.F. Situación del comercio de tilapia em el año 2000.

Panorama Acuícola, v. 6, n. 3, p. 24-27, 2001.

CASTRO, M. R. S.; FREIRE, I. M. G.; ESCOBAR, C. A. M.; ANTUNES, G. M.; FARO, Z. P. Influência da contaminação ambiental nas condições higiênico-sanitárias do peixe curimã (Mugil lisa), oriundo da favela do Caranguejo, Recife - PE. Hig. Aliment., v. 17, n. 109, p. 54-61, jun. 2003.

COOKE, M. Escherichia coli - an overview. J. Hyg.Camb., v. 95, p. 523-530, 1985.

DAMS, R. I.; BEIRÃO, L. H.; TEIXEIRA, E. Avaliação da qualidade microbiológica da pescadinha (Cysnoscion striatus) inteira e em filés nos principais pontos críticos de controle de uma indústria de pescado congelado. Bol. Centro Pesqui. Process. Aliment., v. 14, n. 2, p.151-162, jul./dez., 1996.

DAMS, R. I.; BEIRÃO, L. H.; TEIXEIRA, E. Estudo da viabilidade da implantação de um sistema de análise de risco e pontos críticos de controle de uma indústria de pescado congelado. Rev. Bras. Análise de Alimentos, v. 1, p. 115-130, 1995.

EDELMAN, R.; KARMALI, M.; FLEMING, P. A. Summary of the International Symposium and Workshop on Infections Due to Verocytotoxin (Shiga -Like-Toxin) Producing Escherichia coli. Journal of Infectious Diseases, v. 157, n. 5, p. 1102-1104, 1988. 
ESTEVES, K. E.; MERCANTE, C. T.; SANT'ANA, C. L.; AZEVEDO, M. P.; MATTÉ, M. H.; BALIAN, S. C.; SENDACZ, S.; ISHIKAWA, C. M.; CABIANCA, M. A. A.; LIUSON, E. Diagnóstico ecológico-sanitário de pesqueiros da região metropolitana de São Paulo. v. 1. São Paulo: Relatório FAPESP, 2002. 144 p.

EWING, W. H. Edwards and Ewing's. Identification of Enterobacteriaceas. 4. ed. New York: Elsevier, 1986.

FELL G.; HAMOUDA O.; LINDNER R.; REHMET S.; LIESEGANG A.; PRAGER R.; GERICKE B.; PETERSEN L. An outbreak of Salmonella blockley infections following smoked eel consumption in Germany. Epidemiol. Infect., v. 125, n. 1, p. 912, aug. 2000.

FERNÁNDEZ ESCARTÍN, E.; TORRES VITELA, M. R. Contamination of fish ceviche by Salmonella in Guadalajara, Jalisco, Mexico. Bol. Oficina Sanit. Panam., v. 120, n. 3, p. 198-203, mar. 1996.

FRANCIS, D. H.; MOXLEY, R. A.; ANDRAOS, C. V. Edema disease-like brain lesions in gnobiotic piglets infected with Escherichia coli serotype O157:h7. Infect. Immun., v. 57, p. 1339-1342, 1989.

FRANCO, B. D. G. M. Microbiologia dos alimentos. São Paulo: Atheneu, 1996. 182 p.

GASPAR, A; RANGEL FILHO, F. B. Utilização de carne de tartarugas da Amazônia (Podocnemis expansa), criadas em cativeiro, para consumo humano. Hig. Aliment., v. 15, n. 89, p. 73-78, out. 2001.

GASPAR JR., J. C.; VIEIRA, R. H. S. F.; TAPIA, M. S. R. Aspectos sanitários do pescado de origem de água doce e marinha, comercializado na feira da Gentilândia, Fortaleza - CE. Hig. Aliment., v. 11, n. 51, p. 20-23, 1997.

GERMANO, P. M. L., GERMANO, M. I. S. Higiene e vigilância sanitária de alimentos. São Paulo: Varela, 2001. p 204-208.

GIOMBELLI, A.; SILVA, N. L. Avaliação do método tradicional para detecção de Salmonella spp. em carnes in natura. Hig. Aliment., v. 16, n. 95, p.88-91, abr. 2002.

GONÇALVES, A.; HERNÁNDEZ, C. P. Defumação líquida da anchova (Pomatus saltatrix): efeito do processamento nas propriedades químicas e microbiológicas. Ciên. Tecnol. Alim., v. 18, p. 438-443, 1998.

HEINITZ, M. L.; RUBLE, R. D.; WAGNER, D. E.; TATINI, S. R. Incidence of Salmonella in fish and seafood. Minneapolis: U.S. Food and Drug Administration. 1999.

HOBBS, B. C.; ROBERTS, D. Toxiinfecções e controle higiênico sanitário de alimentos. São Paulo: Varella, 1999. 
HOFFMANN, F. L.; GARCIA-CRUZ, C. H.; VINTURIM, T. M.; FÁZIO, M. L. S. Levantamento da qualidade higiênico-sanitária de pescado comercializado na cidade de São José do Rio Preto (SP). Hig. Aliment., v. 13, n. 64, p. 45-48, 1999.

ICMFS. Microorganismos de los alimentos: Su significancia y métodos de enumeracion. Zaragoza. Acribia, 1978. v. 1.

JAKABI, M.; BUZZO, A. A.; RISTORI, C. A.; TAVECHIO, A. T.; SAKUMA, H.; PAULA, A. M. R.; GELLI, D. S. Laboratorial observation about foodborne salmonellosis outbreaks in Great São Paulo city, from 1994 to 1997. Rev. Inst. Adolfo Lutz, v. 58, n. 1, p. 47-51, 1999.

JORY, D. E.; ALCESTE, C.; CABRERA, T. R. Mercado y comercialización de tilapia en los Estados Unidos de Norteamérica. Panorama Acuícola, v. 5, n. 5, p. 50-53, 2000.

LE MINOR L.; POPOFF M. Y. Request for an opinion. Designation of Salmonella enterica sp. nov. nomrev, as the type and only species of the genus Salmonella. Int. J. Systematic Bacteriol., v. 37, p. 465-468, 1987.

LEITÃO, M. F. F. Aspectos microbiológicos das carnes. In: Curso de higiêne e sanitização em estabelecimentos de produção e industrialização de carne e derivados, 6/7. dez. 1995.

LIMA, M. G.; REIS, R. B. Incidência de Salmonella spp. Comparação entre metodologias de detecção em amostras de pacu (Piaractus mesopotamicus) de rio e cultivado comercializadas no município de Cuiabá - MT. Hig. Aliment., v. 16, n. 101, p.43-49, out. 2002.

LINDER, C. E.; NOGUEIRA-PINTO, J. P. A.; ROÇA, R. O. Salmonella sp. em sistemas intensivos de criação de peixes tropicais de água doce. In: CONGRESSO Brasileiro de Microbiologia, 20., 1999, Salvador. Anais... Salvador, 1999. p. 363.

LIRA, A. A.; BARROS, G. C.; LIMA, E. T.; SILVA, L. B. G. Correlação entre a patogenicidade de Escherichia coli e doenças de origem hídrica. Hig. Aliment., v. 15, n. 85 , p. 57-60, jun. 2001.

LIRA, A. A.; BARROS, G. C.; MOTA, R. A. Vibrio parahaemolyticus em bivalves comercializados no grande Recife, PE. Hig. Aliment., v. 15, n. 90/91, p. 50-59, nov./dez. 2001.

LIRA, G. M.; PEREIRA, W. D.; ATHAYDE, A. H.; PINTO, K. P. Avaliação da qualidade de peixes comercializados na cidade de Maceió, Al. Hig. Aliment., v. 15, n. 84, p. 67-74, maio 2001.

LIUSON, E.; LEME, F. P.; ISHIKAWA, C. M.; BALIAN, S. C. Aplicação de técnica de lavado de pele para pesquisa de enteropatógenos. In: ENCONTRO LATINOAMERICANO DE PATOLOGISTAS DE ORGANISMOS AQUÁTICOS, 3., 2002, Foz do Iguaçu. Anais... Paraná: Associação Brasileira de Patologistas de Organismos Aquáticos, 2002. p. 70. 
LOPALCO, P. L.; GERMINARIO, C.; DI MARTINO, V.; FRISOLI, L.; PAGANO, A.; QUARTO, M.; BARBUTI, S. Dip. di Medicina Interna e Medicina Pubblica, Sezione di Igiene, Universita di Bari. Epidemiologic study and cost analysis of an Salmonella enteritidis epidemic. Ann Ig., v. 12, n. 4, p. 279-285, jul./aug, 2000.

MACHADO, N. A. N.; FEITOSA, T.; VASCONCELOS, M. E. L. Incidência de bactérias do grupo de coliformes fecais em amostras de lagostas beneficiadas em indústrias do estado do Ceará. Bol. Centro Pesqui. Process. Aliment., v. 7, n. 1, p. 33 38, jan./jun. 1989.

MACHADO, I. C.; PAULA, A. M. R.; BUZZO, A.; JAKABI, M.; RISTORI, C.; SAKUMA, H. Estudo da ocorrência de contaminação orgânica no estuário da Cananéia, como subsídio para extração, manejo e cultivo da ostra do mangue (Crassostrea brasiliana). Análise da ostra (tecidos moles e líquido intervalar), 2. Hig. Aliment., v. 15, n. 83, p. 44-48, abr. 2001.

MAGNANI, A. L.; GIOMBELLI, A.; SHUCK, M. S.; BUSATO, M. A.; SILVA, N. L. Incidência de Salmonella e Escherichia coli em carne suína in natura e salame colonial, consumidos pela população de Chapecó - SC. Hig. Aliment., v. 14, n. 73, p. 44-47, jun. 2000 .

MENDES, E. S.; MENDES, P. P.; COELHO, M. I. S.; SOUZA, J. C. R.; CRUZ, M. C. S.; ASSIS, A. S.; ALVES, A. B. Aspectos microbiológicos do camarão Ltopenaeus vannamei defumado e sua vida de prateleira. Hig. Aliment., v. 16, n. 99, p. 75-80, ago. 2002.

MENDONÇA, S. C.; CORREIA, R. T. P.; ALBINO, E. Condições higiênico-sanitárias de mercados e feiras-livres da cidade de Recife - PE. Hig. Aliment., v. 16, n. 94, p.2025 , mar. 2002.

MEURER, F.; HAYASHI, C.; BOSCOLO, W. R. Influência do processamento da ração no desempenho e sobrevivência da tilápia do Nilo durante a reversão sexual. R. Bras.

Zootec., v. 32, n. 2, p. 262-267, mar./abr. 2003.

MOUCHREK FILHO, V. E.; NASCIMENTO, A. R.; MOUCHREK FILHO, J. E.; SANTOS, A. A.; MARINHO, S. C.; MARTINS, A. G. L. A.; GARCIAS JR., A.V.; CHAAR, J. S. Hig. Aliment., v. 17, n. 111, p. 66-72, ago. 2003.

MÖLLERKE, R. O.; WIEST, J. M.; CARVALHO, H. H. C. Colimetrias como indicadores de qualidade de pescado artesanal do lago Guaíba, em Porto Alegre, RS. Hig. Aliment., v. 16, n. 99, p. 102-106, ago. 2002.

MURATORI, M. C. S.; PEREIRA, M. M. G.; SOARES, L. R. Pesquisa de bactérias potencialmente patogênicas em pescado comercializado no mercado central de Teresina - PI. Bol. Centro Pesqui. Process. Aliment., v. 12, n. 1, p. 33-38, jan./jun. 1994.

MURATORI, M. C. S., MARTINS, N. E., PEIXOTO, M. T. D. Mortalidade por "septicemia dos peixes tropicais" em tilápias criadas em consorciação com suínos. Arq. Bras. Med. Vet. Zootec., v. 53, n. 6, p. 658-662, dez. 2001. 
NASCIMENTO, A R.; MOUCHREK FILHO, J. E.; CARVALHO, P. A. B.; COSTA, A. C.; CAVALCANTE, P. R. S.; VIEIRA, R. H. S. F. Colimetria das águas do Rio Bacanga (S. Luis, Maranhão), de peixes e sururus capturados em suas águas. Hig. Aliment., v. 15, n. 84, p. 59-66, maio 2001.

NASCIMENTO, A R.; MOUCHREK FILHO, J. E.; TATY, S. R. Pesquisa de coliformes e Staphilococcus enteropatogênicos em camarões salgados e secos comercializados nos mercados e feiras-livres de São Luís, MA. Hig. Aliment., v. 15, n. 85 , p. 65-68, jun. 2001.

NASCIMENTO, A. R.; VALLE, R. H. P.; BOARI, C. A.; ALCÂNTARA, E. M. C.; VIEIRA, R. H. S. F. Avaliação da presença de Salmonella e de outras bactérias da família Enterobacteriaceae em massa de quibe comercializada na cidade de Lavras, MG. Hig. Aliment., v. 16, n. 102/103, p.85-88, nov./dez. 2002.

NORMAM, G. R.; STREINER, D. L. Biostatistics: the bare essentials. St Louis: Mosby, 1994.

O 'GRADY, K. A.; KRAUSE, V. An outbrake of Samonellosis linked to a marine turtle. Southeast Asian J. Trop. Med. Public Health., v. 30, n. 2, p. 324-327, 1999.

OLIVA, C. A. G; SCALETSKY, I; MORAIS, M. B.; FAGUNDES NETO, U. Diarréia aguda grave associada à Escherichia coli enteropatogênica clássica (EPEC): características clínicas e perdas fecais em lactentes hospitalizados. Rev. Assoc. Med. Bras., v. 43, n. 4, p. 283-289, out./dez. 1997.

OLIVEIRA, J. S.; FREITAS, J. C. Produtos naturais marinhos: características dos envenenamentos alimentares e substâncias de interesse farmacológico. Hig. Aliment., v. 15 , n. 80/81, p. 22-33, jan./fev. 2001.

ORSKOV, I.; ORSKOV, F. Escherichia coli in extraintestinal infections. J. Hyg. Camb., v. 95, p. 551-575, 1985.

PALMA, C. S. C. Controle de qualidade higiênico sanitária em matadouros frigoríficos de bovinos através do sistema APPCC, para produção de zoonoses de origem alimentar, 1998. Tese. Faculdade de Medicina Veterinária e Zootecnia Universidade de São Paulo, São Paulo, 1998

PEIXOTO, M. R. S.; SOUSA, C. L.; MOTA, E. S. Utilização de pescada (Macrodom ancylodon) de baixo valor comercial para obtenção de surimi empregado na elaboração de salsicha com sabor de camarão. Hig. Aliment., v. 16, n. 99, p. 95-101, ago. 2002.

PIMENTEL, L. P. S.; PANETTA, J. C. Condições higiênicas do gelo utilizado na conservação de pescado comercializado em supermercados da grande São Paulo. Parte 1, resultados microbiológicos. Hig. Aliment., v. 17, n. 106, p. 56-63, mar. 2003.

POPMA, T. J.; LOVSHIN, L. L. Worldwide prospects for commercial production of tilapia. Alabama: International Center for Aquaculture, 1996. 23 p. (Research and Development Series, 41). 
PROENÇA, E. C. M.; BITTENCOURT, P. R. L. Manual de piscicultura tropical. Brasília: IBAMA, 1994.

POPOFF, M. Y.; BOCKEMUHL, J.; MCWHORTER-MURLIN, A. Supplement 1993 (No. 37) to antigenic formulas of the salmonella serovars. WHO Collaborating Centre for Reference and Research on Salmonella. Institute Pasteur, Paris. Kauffmann-White scheme. Res. Microbiol., v. 145, p. 711-716, 1993.

REDMAYNE, P. Como el camarón y el salmon de cultivo la tilapia se está conviertiendo rápidamente em un proveedor de filetes frescos y congelados de alta calidad. Virtualmente todos los filetes de tilapia vendidos em los Estados Unidos son importados. Panorama Acuícola, v. 5, n. 3, p. 8-9, 2000.

REIS, J. D. P.; FARIA, N. C. Surtos de toxinfecção alimentar ocorridos no Distrito Federal no período de 1994 a 1997. Rev. saúde Dist. Fed., v. 9, n. 3, p. 27-31, jul./set. 1998.

ROSAS PÉREZ, I.; YELA MIRANDA, A.; MEZA MENESES, G.; PÉREZ

MARTÍNEZ, J.; ROMO GARCÍA, A. L.; ALMANZA MÁRQUEZ, Y. Cuantificación de bacterias coliformes y aislamientos de Salmonella en ostiones crudos colectados en un mercado de mariscos. Rev. Fac. Med. UNAM., v. 31, n. 2, p. 39-42, mar./abr. 1998.

SABIONI, J. G. Avaliação da eficiência do filtro de areia na redução microbiana em água de consumo humano. Hig. Aliment., v. 15, n. 84, p. 75-78, maio 2001.

SANTOS, C. C. M.; PERSI, J. T. M.; LIMA, S. I.; BRIGHETTI, J. M. P.; NASCIMENTO, S. C.; ZENEBOM, O. Qualidade da água de origem subterrânea oferecida à população, na região de São José do Rio Preto (SP), no período de 1991 a 1999. Hig. Aliment., v. 15, n. 82, p. 47-51, mar. 2001.

SANTOS, M. G.; VIEIRA, R. H. S. F.; IARIA, S. T.; SOUSA, O. V. Coliformes isolados de utensílios e equipamentos, na linha de processamento de camarão, de uma indústria de pescado de Fortaleza, Ceará. Hig. Aliment., v. 16, n. 101, p.67-75, out. 2002 .

SCHMITTOU, H. R. High density fish culture in low volume cages. Singapore: American Soybean Association, 1993. 78 p.

SILVA, C. M.; SÃO CLEMENTE, S. C. Nematóides da família Anisakidae e cestóides da ordem Trypanoryncha em filés de dourado (Coryphaena hippurus) e ariocó (Lutjanus synagris) e suas importância na inspeção de pescado. Hig. Aliment., v. 15, n. 80/81, p. 22-33, jan./fev. 2001.

SILVA, E. F.; SALGUEIRO, A. A. Avaliação da qualidade bacteriológica de água de poços na região metropolitana de Recife - PE. Hig. Aliment., v. 15, n. 90/91, p. 73-78, nov./dez. 2001.

SILVA, E. N. Características de patogenicidade em amostras Escherichia coli de origem aviária. São Paulo. 1986. 80f. Tese - Faculdade de Medicina Veterinária e Zootecnia, Universidade de São Paulo, São Paulo, 1986. 
SILVA, M. C. D.; NORMANDE, A. C. L.; FERREIRA, M. V.; RAMALHO, L. S. Avaliação da qualidade microbiológica de pescado comercializado em Maceió, AL. Hig. Aliment., v. 16, n. 96, p. 60-64, maio 2002.

SILVA, N.; JUNQUEIRA, V. C. A.; SILVEIRA, N. F. A. Manual de métodos de análises microbiológica de alimentos. São Paulo: Varela, 1997. p. 7- 20.

SOUSA, M. R. P.; COSTÊLHA, S. S.; OLIVEIRA, V. M. Helmintoses com relevância em saúde pública, transmissíveis através da água e dos alimentos. Hig. Aliment., v. 15, n. 90/91, p. 19-24, nov./dez. 2001.

SOUZA, M. L. R. Comparação de seis métodos de filetagem, em relação ao rendimento de filé e de subprodutos do processamento da Tilápia-do-Nilo (Oreochromis niloticus). R. Bras. Zootec., v. 31, n. 3, p.1076-1084, jun. 2002.

SNOEYENBOS, G. H. Avian salmonellosis. In: BERAN, G. W. Handbook of zoonoses. 2nd ed. Boca Raton, Florida. 1994.

STEMPNIEWSKI, H. L. Doenças parasitárias dos peixes. Generalidades. Poluição e piscicultura. São Paulo: Faculdade de Saúde Pública da USP e Instituto de Pesca, 1986. $216 \mathrm{p}$.

STOSKOPF, M. K. Zoonotic diseases. In: NEMETZ, T. G.; SHOTTS, E. B. Fish medicine, W. B. Saunders, 1993. p. 214-215.

SUSSMAN, M. Escherichia coli and human disease. In: SUSSMAN, M. Escherichia coli mechanisms of virulence. Cambridge: University Press, 1997. p. 3-48

TAYLOR, R.; SLOAN, D.; COOPER, T.; MORTON, B.; HUNTER, I. Central Public Health Unit Rockhampton, Queensland. A waterborne outbreak of Salmonella Saintpaul. Australia. Commun Dis Intell., v. 24, n.11, p. 336-340, 2000.

TESSARI, E. N. C.; CARDOSO, A. L. S. P.; CASTRO, A. G. M.; ZANATTA, G. F. Prevalência de Salmonella enteritidis em carcaças de frango industrialmente processadas.

Hig. Aliment., v. 17, n. 107, p. 52-55, abr. 2003.

TSUJI, H; HAMADA, K. Outbreak of Salmonella Chester and Salmonella Oranienburg. Jpn. Infect. Dis., n. 52, p. 138-139, 1999.

U.S. FOOD \& DRUG ADMINISTRATION: Center for Food Safety \& Applied Nutrition Foodborne. Pathogenic microorganisms and natural toxins handbook. Disponível em: $<$ http://vm.cfsan.fda.gov/ mow/chap1.html >. Acesso em 4 maio 2001.

VEIGA, S. M. O. M..; NASCIMENTO, E. P.; CARDOSO, C. C.; FIORINI, J. E. Eficácia da água ozonizada contra patógenos encontrado em água e alimentos. Hig. Aliment., v. 17, n. 106, p. 95-99, mar. 2003. 
VIEIRA, K. V. M.; MAIA, D. C. C.; JANEBRO, D. I.; VIEIRA, R. H. F.; CEBALLOS, B. S. O. Influência das condiçöes higiênico-sanitárias no processo de beneficiamento de tilápias (Oreocrhomis niloticus) em filés congelados. Hig. Aliment., v. 14 , n. 74 , p. 37-40, jul. 2000.

VIEIRA, K. V. M.; MAIA, D. C. C.; JANEBRO, D. I. et. al. Qualidade microbiológica de peixes processados num pequeno frigorífico e associação com a qualidade da água do açude de criação. In.: CONGRESSO LATINO AMERICANO DE MICROBIOLOGIA E HIGIENE DE ALIMENTOS - SIMPÓSIO BRASILEIRO DE MICROBIOLOGIA DE AliMENTOS, 5., 1998, Águas de Lindóia. Anais...São Paulo, 1998. p. 128.

VIEIRA, R. H. S. F.; BARROS, L. M. o.; SILVA, A. I. M.; TAKAKI, G. M. C. Qualidade microbiológica do mapará (Hypophtalmus edentatus) salgado, comercializado em Fortaleza, CE. Hig. Aliment., v. 15, n. 85, p. 61-64, jun. 2001.

VIEIRA, R. H. S. F.; OLIVEIRA, R. A. Avaliação do grau de contaminação fecal da água e do camarão sossego (Macrobrachium jelskii), na Lagoa de Parangaba (Fortaleza, Ceará). Hig. Aliment., v. 15, n. 80/81, p. 69-74, jan./fev. 2001. 